UNIVERSIDADE DE SÃO PAULO

INSTITUTO DE FÍSICA DE SÃO CARLOS

THALITA VERÔNICA CALHEIROS ROLIM

SÍNTESE E FUNCIONALIZAÇÃO DE NANOPARTÍCULAS COM OLIGONUCLEOTÍDEO PARA APLICAÇÃO EM GENOSSENSORES NO DIAGNÓSTICO AVANÇADO DE PREDISPOSIÇÃO À HIPERTENSÃO ARTERIAL 



\section{SÍNTESE E FUNCIONALIZAÇÃO DE NANOPARTÍCULAS COM OLIGONUCLEOTÍDEO PARA APLICAÇÃO EM GENOSSENSORES NO DIAGNÓSTICO AVANÇADO DE PREDISPOSIÇÃO À HIPERTENSÃO}

\section{ARTERIAL}

Dissertação apresentada ao Programa de PósGraduação em Física do Instituto de Física de São Carlos da Universidade de São Paulo, para obtenção do título de Mestre em Ciências.

Área de concentração: Física Aplicada

Opção: Física Biomolecular

Orientador: Prof. Dr. Valtencir Zucolotto

\section{Versão Corrigida \\ (Versão original disponível na Unidade que aloja o Programa)}

\section{São Carlos}


AUTORIZO A REPRODUÇÃO E DIVULGAÇÃO TOTAL OU PARCIAL DESTE TRABALHO, POR QUALQUER MEIO CONVENCIONAL OU ELETRÔNICO PARA FINS DE ESTUDO E PESQUISA, DESDE QUE CITADA A FONTE.

Ficha catalográfica elaborada pelo Serviço de Biblioteca e Informação do IFSC, com os dados fornecidos pelo(a) autor(a)

Rolim, Thalita Verônica Calheiros

Síntese e funcionalização de nanopartículas com oligonucleotídeo para aplicação em genossensores no diagnóstico avançado de predisposição à hipertensão arterial / Thalita Verônica Calheiros Rolim; orientador Valtencir Zucolotto - versão corrigida -São Carlos, 2013.

$129 \mathrm{p}$.

Dissertação (Mestrado - Programa de Pós-Graduação em Física Aplicada Biomolecular) -- Instituto de Física de São Carlos, Universidade de São Paulo, 2013.

1. Hipertensão Arterial. 2. Polimorfismo I/D. 3. Nanopartículas. 4. Nanoconjugado. 5. Genossensores. I. Zucolotto, Valtencir, orient. II. Título. 
A Deus, pelo amor incondicional

e presença constante na minha vida. 



\section{AGRADECIMENTOS}

Por ser a minha força e a minha coragem nos momentos difíceis, minha alegria e a minha felicidade nos momentos maravilhosos, por ser Tudo e Todo na minha vida, Agradeço a Deus!

Ao Prof ${ }^{\circ}$ Dr. Valtencir Zucolotto minha mais sincera gratidão pela grande oportunidade e confiança, pela agradável convivência e pelo seu lado humano. Xuxa, Muito Obrigada!

Aos meus Pais, Vera e Walter, e ao meu Irmão, Michel, que são a base da minha formação pessoal, pelo exemplo incontestável de dignidade e simplicidade, pelo apoio, pela paciência e, principalmente, pelo amor, que fundamentalmente fazem da minha vida especial. Orgulho de vocês. Obrigada Família Querida!

Á minha querida Vó, Dalva, pelo amor, pela amizade, pela verdade e pela vida. Obrigada por tudo Vó, uma vida toda seria pouco para te agradecer, para te amar e para te ter. Além do amor!

Ao meu Vô, Milton, que junto ao Pai está "olhando por mim", pelo exemplo singular de simplicidade e doçura, obrigada Vô!

Á toda minha família, Obrigada!

Ao Bruno, por todos os momentos ao seu lado, pelo apoio, pela paciência, pelo nosso relacionamento, que me transforma em uma pessoa melhor a cada dia. Pela esperança, pelos sonhos, pelo sorriso que sempre me espera, pelo brilho que me ilumina, pela bondade, pela amizade e pelo amor. Sua existência na minha vida é um verdadeiro presente de Deus. Espero que esse seja só mais um dos tantos momentos ao seu lado. Meu amor, muito obrigada! Eu Amo Você

Á Fapesp pela bolsa de mestrado outorgada e todo apoio financeiro necessário para a realização deste trabalho.

Ao CNPq e a Capes pelo apoio financeiro.

Ao Instituto de Física de São Carlos e a Universidade de São Paulo pelo apoio, estrutura, corpo de docente e funcionários, que juntos foram essenciais para a realização deste trabalho.

Aos docentes e funcionários do Grupo de Biofísica Molecular "Sérgio Mascarenhas", em especial, as técnicas Bel e Andressa, e as secretárias Ester e Julielle, que além de nos auxiliar muito, mantém o ambiente de trabalho sempre organizado e agradável. 
Ao Prof ${ }^{\circ}$ Dr. Francisco Eduardo Contijo Guimarães pela ajuda na realização das imagens de Microscopia Confocal de Fluorescência, pela humildade e simplicidade!

Ao Centro Universitário Hermínio Ometto pela base profissional, estrutura, apoio, corpo de docentes e funcionários. Em especial, as Professoras Maria Esméria e Camila. Não tenho palavras para agradecer todo apoio e toda confiança depositada em mim durante todos esses anos. Obrigada por tudo!

Á Lari e a Vê, os meus pontinhos fora da reta mais queridos (risos), por todos os momentos de descontração, de alegria, de esperança e por toda amizade incontestável. Obrigada meninas!

Á Ju pela sincera amizade, pelas conversas e conselhos diários, pelos incontáveis desabafos (risos), pela confiança, pelos experimentos e pelos nossos happy hour, Obrigada Ju!

Á Valerinha pela extrema humildade e doçura, pela amizade e confiança, pela colaboração nas imagens de Microscopia Eletrônica de Transmissão e pela grande ajuda no laboratório. Obrigada Val!!

Ás minhas anjinhas Vivis, Lets e Blubis. Não tenho palavras para descrever a presença e amizade de vocês na minha vida! Vivis, presente em todas as fases acadêmicas (risos), primeiramente, obrigada pela eterna amizade durante o cursinho, nos tempos da faculdade, e pela ajuda e abrigo no meu início em São Carlos, todos os momentos foram especiais para mim. Nunca vou me esquecer de nós naquela festa matine do Biju, lembra?! (risos) sem comentários, nem da gente procurando naquele mapa gigante as cidades de Araras e São Carlos, lembra? Quem diria que a gente estaria um dia na mesma cidade, na mesma casa... Lets, um verdadeiro presente de Deus na minha vida, obrigada pelas sábias palavras, e por fazer Deus tão presente e tão emocionante em nossas vidas! Blubis, ah Blubis, dindinha, que alegria, que gordices (risos), que beleza, obrigada pela paz e felicidade que a sua amizade me traz. Obrigada anjinhas! Feliz por ter vocês na minha história.

Aos amigos de Arujá, á Suelen que desde o colégio me faz ver que a vida pode ser alegre na dificuldade, forte nas desilusões e sustentável com as amizades. Á Cintia, pela alegria e força, pelas palavras e pelo carinho. Á Carol, que desde "pequenininha" me inspira e me motiva sempre. Ao Jacques pela amizade. "Verdadeiras amizades continuam a crescer mesmo a longas distâncias, e o que importa não é o que você tem na vida, mas que você tem na vida". Obrigada meus amigos!

Aos amigos do LNN e do Grupo de Biofísica: Fabrício, Edson, Nirton, Camilo, Wagner, Felipe, Bruno, Rodrigo, Charles, Luís, Leandro, Débora, Sumária, Lilian, Karina, Laís, Denise, Iêda, Letícia, Patrícia, Monique. Obrigada por compartilharem comigo suas conquistas e tristezas, seus sonhos e realizações. 
A todos que passaram pela minha vida, mas deixaram um pouco de si e levaram um pouco de mim. E a todos que contribuíram direta e indiretamente para a realização deste trabalho. Muito Obrigada! Que Deus abençoe todos! 

"E a doçura é tanta...

Que faz insuportável cócega na alma.

Viver é mágico,

E inteiramente inexplicável."

Clarice Lispector 



\section{RESUMO}

ROLIM, T. V. C. Síntese e funcionalização de nanopartículas com oligonucleotídeo para aplicação em genossensores no diagnóstico avançado de predisposição à hipertensão arterial. 2013. 129 p. Dissertação (Mestrado em Ciências) - Instituto de Física de São Carlos, Universidade de São Paulo, São Carlos, 2013.

A crescente prevalência de hipertensão arterial na população mundial e os riscos por ela apresentados nas doenças coronarianas eleva a importância de seu controle. Sendo sua causa, frequentemente multifatorial, o tratamento da patologia é dificultado. Fatores ambientais associados à predisposição genética levam o indivíduo a apresentar índices pressóricos elevados de pressão arterial quando comparados a indivíduos que não apresentam tal predisposição. Identificar a predisposição genética seria ideal para amenizar ou, até mesmo, evitar o desenvolvimento da patologia. As nanopartículas estão cada vez mais associadas com biomoléculas, uma vez que suas propriedades associadas às questões médicas podem criar novos métodos potencialmente eficientes, tanto no diagnóstico como na terapêutica. $\mathrm{O}$ presente trabalho teve como objetivo a conjugação de nanopartículas de ouro, estabilizadas com dendrímero poli(amidoamina) de geração 4, com oligonucleotídeo para obtenção de genossensores capazes de detectar o polimorfismo de inserção e deleção do gene da enzima conversora de angiotensina I, o qual está intimamente relacionado com a predisposição à hipertensão arterial sistêmica. As nanopartículas foram caracterizadas por Microscopia Eletrônica de Transmissão (TEM), potencial zeta e Espectroscopia no Ultravioleta-Visível (UV-VIS). A formação do conjugado entre a nanopartícula e o oligonucleotídeo foi confirmada por UV-VIS, Espalhamento Dinâmico de Luz (DLS) e Espectroscopia no Infravermelho com Transformada de Fourier (FTIR). Foram construídos três sistemas de detecção diferentes, nos quais as técnicas empregadas foram Espectroscopia de Impedância Elétrica, Espectroscopia de Impedância Eletroquímica e Transistor de Efeito de Campo de Porta Estendida e Separada (SEGFET). O polimorfismo foi detectado em concentrações da ordem de $1 \mathrm{nM}$. Com destaque para aqueles em que o emprego do conjugado amplificou o sinal pelas propriedades das nanopartículas de ouro. Os genossensores propostos são promissores e futuramente poderão contribuir com a medicina preventiva.

Palavras-chave: Hipertensão Arterial. Polimorfismo I/D. Nanopartículas. Nanoconjugado. Genossensores. 



\begin{abstract}
ROLIM, T. V. C. Synthesis and functionalization of nanoparticles with oligonucleotide for application in genosensors as advanced diagnostic tools for arterial hypertension. 2013. 129 p. Dissertação (Mestrado em Ciências) - Instituto de Física de São Carlos, Universidade de São Paulo, São Carlos, 2013.
\end{abstract}

The increasing prevalence of hypertension in the world population and the risks presented by it in coronary heart disease reveals the importance of their control. Due to its multifactorial causes, the treatment of this disease is difficult. Environmental factors associated with genetic predisposition lead the individual to present high indexes of blood pressure when compared to individuals who do not have a predisposition. To identify the genetic predisposition would be ideal to minimize or even to prevent the pathology development. Nanoparticles are increasingly associated with biomolecules, their properties added with medical questions, can create new methods potentially efficient, both in diagnosis and therapy. This study aims at developing of poly(amidoamine) dendrimer-stabilized gold nanoparticles, conjugated with oligonucleotides to obtain genosensors able to detect the polymorphism of insertion and deletion of angiotensin I converting enzyme (ACE) gene, which is closely related with the predisposition to systemic blood hypertension. The nanoparticles were characterized by Transmission Electronic Microscopy (TEM), Zeta potential and Ultraviolet-Visible Spectroscopy (UV-VIS). The formation of the conjugate formed by the nanoparticle and the oligonucleotide was confirmed by UV-VIS, Dynamic Light Scattering (DLS) and Fourier Transform Infrared Spectroscopy (FTIR). Three different detection systems were built, in which the following techniques were applied: Electrical Impedance Spectroscopy, Electrochemical Impedance Spectroscopy and Separative Extended Gate Field Effect Transitor (SEGFET). For all systems polymorphism - related sequences were detected at concentrations down to nanomolar. The use of the conjugate amplified the signal of the genosensor due to the nanoparticles. The proposed genosensors may contribute to preventative medicine.

Keywords: Blood Hypertension. Polymorphism I/D. Nanoparticles. Nanoconjugate. Genosensors. 



\section{LISTA DE FIGURAS}

Figura 1 - Esquema de funcionamento de um biossensor.

Figura 2 - Esquema de um sensor de DNA. Imobilização das sequências de DNA, onde um linker (spacer) bifuncional é utilizado para ancorar o DNA na plataforma (a). Funcionamento de um sensor de DNA: sequências imobilizadas $\rightarrow$ hibridização $\rightarrow$ captura do sinal (b).

Figura 3 - Esquema da molécula de DNA em conformação de dupla hélice. Estruturada pelo grupo fosfato ligado na pentose, ligação fosfodiéster, juntos representam o "esqueleto" molecular do DNA. A hibridização com a sequência complementar ocorre pelas bases nitrogenadas (adenina, timina, citosina ou guanina). As purinas (adenina e guanina) hibridizam apenas com as pirimidinas (timina e citosina) e sempre de maneira a manter a mesma distância entre as duas fitas na sequência toda. Assim, a guanina apenas se liga na citosina e a timina apenas na adenina ${ }^{42}$.

Figura 4 - Estratégia para detectar sequências complementares de DNA alvo em genossensores com formato de hibridização tipo sanduíche. I) Ancoragem da sequência de captura; II) Imobilização da sequência alvo complementar ( $1^{a}$ hibridização); III) Hibridização da sequência repórter, contendo um marcador na parte superior, com a sequência alvo ( $2^{a}$ hibridização).

Figura 5 - Estratégia para detectar sequências complementares de DNA alvo em genossensores com formato de hibridização direta. I) Ancoragem da sequência de captura; II) Hibridização com a sequencia alvo complementar e captura do sinal.

Figura 6 - Diagrama esquemático de um MOSFET (a) e de um ISFET $(b)^{52}$

Figura 7 - Diagrama esquemático de um SEGFET. P, F e D representam, respectivamente, os eletrodos porta, fonte e dreno, de um MOSFET comercial.

Figura 8 - Esquema de funcionamento da homeostase de pressão arterial sistêmica, realizado pelo Sistema Renina Angiotensina Aldosterona (SRAA). Adaptado de Aria Rad - $2006^{67}$.

Figura 9 - Estrutura molecular do dendrímero poli(amidoamina) de geração 4 - PAMAM G4 ${ }^{78}$.

Figura 10 - Imagem das soluções na etapa inicial e final da síntese das nanopartículas de ouro, a) o sistema ainda na coloração amarela clara, permaneceu em agitação vigorosa constante em um agitador magnético e b) após 2,5 horas de agitação constante e protegido da luz a suspensão das nanopartículas de ouro está concluída, e apresenta uma coloração vermelha acastanhada, indicando a redução do ouro. 
Figura 11 - Estrutura química de um fosfodiester e um fosforotioato. A alteração entre eles é a troca de um oxigênio (-O) do grupo fosfato por um enxofre $(-S)^{80}$.

Figura 12 - Imagem dos microeletrodos interdigitados recobertos com ouro utilizados como plataforma do genossensor elétrico.

Figura 13 - Esquema de plataformas com a molécula imobilizada pura e com SAM mix: (a) apenas sequências de

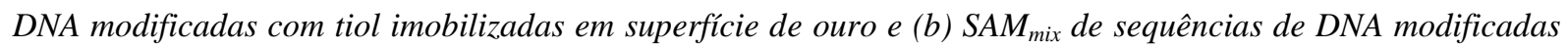
com tiol e 6-hidroxi-1-hexanotiol imobilizadas em superfície de ouro. ${ }^{79}$.... . .60

Figura 14 - Uma representação esquemática: a) eletrodo interdigitado utilizado em medidas de impedância elétrica, uma plataforma de vidro é separada por dois condutores criando uma região de isolamento entre eles, as moléculas podem se ancorar na região da plataforma ou nos condutores, quando o sinal é aplicado a resistência da transferência de cargas pode aumentar ou diminuir dependendo da molécula imobilizada e b) um típico diagrama de Nyquist representando a impedância complexa e os parâmetros relacionados, descritos acima. Adaptado de Katz et al. - 2010

Figura 15 - Imagem do sistema utilizado nas medidas AC. Onde aparecem o notebook usado para aquisição de dados, o eppendorf® de medida e o impedanciômetro Solartron.

Figura 16 - Representação esquemática do sistema de medida eletroquímico: onde um potenciostato é associado a uma célula eletroquímica convencional de três eletrodos.

Figura 17 - Imagem do sistema utilizado na caracterização eletroquímica. Onde aparecem o computador usado para aquisição de dados, a célula eletroquímica, o potenciostato PGSTAT4O Autolab utilizados nas detecções e o eletrodo de ouro com a área delimitada utilizado na construção do genossensor. .. 73

Figura 18 - a) Diagrama esquemático do dispositivo SEGFET utilizado no genossensor e b) O diagrama eletrônico do mesmo.

Figura 19 - a) Imagem de Microscopia eletrônica de transmissão (TEM) das nanopartículas de ouro (AuNPPAMAM G4) e b) Histograma de tamanhos das AuNP-PAMAM G4.

Figura 20 - a) Espectro de absorbância das AuNP-PAMAM G4 em várias concentrações e b) Gráficos dos valores de absorção máxima na banda de ressonância plasmonica de superfície (524 nm) em função das concentrações, ajustadas linearmente.

Figura 21 - Espectro de absorbância no UV-VIS das AuNP-PAMAM G4, do oligonucleotídeo e do conjugado AuNP-PAMAM G4/Oligonucleotídeo.

Figura 22 - Espectro de absorbância no UV-VIS da solução de síntese, do sobrenadante e do precipitado ressuspendido (conjugado AuNP-PAMAM G4/Oligonucleotídeo).. 
Figura 23 - Histogramas da distribuição de tamanhos obtidos por DLS para as amostras a) AuNP-PAMAM G4 e b) AuNP-PAMAM G4/Oligonucleotídeo. As análises foram realizadas em água ultrapura, pH entre 6,8 e 7,0.

Figura 24 - Espectros de FTIR das amostras AuNP-PAMAM G4, Oligonucleotídeo livre e AuNP-PAMAM G4/Oligonucleotídeo.

Figura 25 - Espectros de fluorescência da PCR em tempo real. Unidades de fluorescência (RFU) em função do número de ciclos de amplificação. Primer controle concentração de 0,3 $\mu \mathrm{mol} L^{-1}$, variando a concentração de

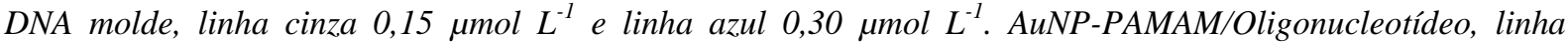
vermelha 0,15 $\mu \mathrm{mol} L^{-1}$ DNA molde e 0,30 $\mu \mathrm{mol} L^{-1}$ de conjugado e linha rosa 0,30 $\mu \mathrm{mol} L^{-1}$ DNA molde e 0,60 $\mu \mathrm{mol} L^{-1}$ de conjugado.

Figura 26 - a) Diagrama de Nyquist representando a impedância complexa de concentrações diferentes de tampão TE e b) Diagrama de Nyquist com zoom na região de 0 a $4 \mathrm{~K} \Omega \mathrm{cm}^{2}$ da componente real da impedância. As análises foram realizadas em tampão TE $0,05 \mathrm{~mol} \mathrm{~L}^{-1} \mathrm{pH}=7,4$. 86

Figura 27 - a) Diagrama de Nyquist representando a impedância complexa das etapas de construção e detecção do genossensor e b) Diagrama de Nyquist com zoom na região de 0 a 3,5 $\mathrm{K} \Omega \mathrm{cm}^{2}$ da componente real da impedância. As análises foram realizadas em tampão TE 0,05 $\mathrm{mol} \mathrm{L}^{-1} \mathrm{pH}=7,4$..... 86

Figura 28 - Etapas de detecção e construção do genossensor em modelo de hibridização sanduíche. Imobilização por meio de $S A M_{m i x}$ (sequência de captura +2-ME), primeira hibridização com a sequência alvo e segunda hibridização com o AuNP-PAMAM G4/Oligonucleotídeo.

Figura 29 - a) Diagrama de Nyquist representando a impedância complexa do ensaio sem a utilização dos AuNP-PAMAM G4/Oligonucleotídeo no genossensor e b) Diagrama de Nyquist representando a impedância complexa das etapas de construção do genossensor e detecção do AuNP-PAMAM G4/Oligonucleotídeo. As análises foram realizadas em tampão $\mathrm{PBS}, \mathrm{pH}=7,4$ contendo $5 \mathrm{mM}\left[\mathrm{Fe}(\mathrm{CN})_{6}\right]^{3-14-}$ 88

Figura 30 - Diagrama de Nyquist representando as impedâncias complexas para diferentes concentrações de sequência alvo $\left(1,10,20,30\right.$ e $\left.40 \mathrm{nmol} \mathrm{L}^{-1}\right)$ após a primeira hibridização nos eletrodos modificados com $S_{\text {SA }} M_{\text {mix }}$ $(D N A$ captura + 2-ME). A linha em vermelho representa a impedância dessa modificação. As análises foram realizadas em tampão $\mathrm{PBS}, \mathrm{pH}=7,4$ contendo $5 \mathrm{mM}\left[\mathrm{Fe}(\mathrm{CN})_{6}\right]^{3-14-}$. 90

Figura 31 - Diagrama de Nyquist representando as impedâncias complexas para diferentes concentrações de AuNP-PAMAM G4 presente nos AuNP-PAMAM G4/Oligonucleotídeo após hibridização com sequência alvo ancorada $\left(0,26 \mathrm{nmol} \mathrm{L}^{-1}\right)$ no eletrodo modificado com $S_{A M} M_{\text {mix }}(D N A+2-M E)$. As análises foram realizadas em tampão $\mathrm{PBS}, \mathrm{pH}=7,4$ contendo $5 \mathrm{mM}\left[\mathrm{Fe}(\mathrm{CN})_{6}\right]^{3-/ 4-}$

Figura 32 - Imagens de microcopia confocal de fluorescência das etapas de construção e detecção do genossensor: a) Imobilização por meio de $S_{A M} M_{\text {mix }}$ (sequência de captura $+2-M E$ ), b) Primeira hibridização 
com a sequência alvo e c) Segunda hibridização com o AuNP-PAMAM G4/Oligonucleotídeo. Posteriormente cada etapa os eletrodos foram submetidos a um banho em uma solução 0,1 $\mu \mathrm{g} \mathrm{mL}^{-1}$ de brometo de etídio e lavados em água ultrapura abundantemente. Escala em amarelo $(5 \mu \mathrm{m})$.

Figura 33 - Microscopia confocal de fluorescência em 3D. Todos os eletrodos de ouro foram submetidos ao banho de brometo de etídio posterior a modificação com um SAM mix contendo sequências de captura e de 2mercaptoetanol (2-ME). a) imagem obtida após a primeira hibridização com sequência alvo e b) após a segunda hibridização com o AuNP-PAMAM G4/Oligonucleotídeo.

Figura 34 - Curva de $I_{D S}$ tomada ao longo do tempo com sequência de captura $\left(S A M_{m i x}\right)$ e depois de hibridizar com a sequência alvo.

Figura 35 - Curvas características $I_{D S} x V_{D S}$ do dispositivo SEGFET tomada da sequência de captura e depois da hibridização com a sequência alvo.

Figura 36 - Curvas características $I_{D S} x V_{G S}$ para um pequeno valor de $V_{D S}\left(V_{D S}=0,2 V\right)$ do dispositivo SEGFET tomada da sequência de captura e depois da hibridização com a sequência alvo. O Inset com zoom na região de 14 a $21 \mu \mathrm{A}$ da corrente $I_{D S}$

Figura 37 - a) Curva de $I_{D S}$ tomada ao longo do tempo com a sequência de captura, sequência não complementar e depois da hibridização com a sequência alvo, b) Curvas características $I_{D S} x V_{D S}$ do dispositivo SEGFET tomada da sequência de captura, sequência não complementar e depois da hibridização com a sequência alvo e c) Curvas características $I_{D S} x V_{G S}$ para um pequeno valor de $V_{D S}\left(V_{D S}=0,2\right.$ V) tomada da sequência de captura, sequência não complementar e depois da hibridização com a sequência alvo. O Inset (c) com zoom na região de 11 a $21 \mu \mathrm{A}$ da corrente $I_{D S}$ 


\section{LISTA DE TABELAS}

Tabela 1 - Classificação diagnóstica da hipertensão arterial (> 18 anos de idade).

Tabela 2 - Sequências utilizadas na construção do genossensor com detecção elétrica.

Tabela 3 - Sequências utilizadas na construção do genossensor com detecção eletroquímica.

Tabela 4 - Sequências utilizadas na construção do genossensor com detecção SEGFET. 54

Tabela 5 - Descrição dos reagentes utilizados na Real-Time PCR........ 66

Tabela 6 - Potencial Zeta obtido para as amostras: AuNP-PAMAM G4, Oligonucleotídeo livre e AuNPPAMAM G4/Oligonucleotídeo, em água ultrapura $\mathrm{pH}=7,0$.

Tabela 7 - Principais atribuições propostas para as bandas encontradas na análise por espectroscopia no infravermelho (FTIR) 



\section{LISTA DE ABREVIATURAS E SIGLAS}

A

$\mathrm{ADH}$

Alelo D

AuNPs

DD

DI

DLS

DNA

$\varepsilon$

ECA

EDTA

FTIR

HAS

II

$\ell$

PAMAM G4

PBS

PCR

PCR em tempo real

Potencial $(\zeta)$

SEGFET

SRAA

TE

TEM

Tris

UV-VIS
Absorbância

Hormônio antidiurético

Alelo com deleção

Nanopartículas de ouro

Alelo de Deleção/ Alelo de Deleção

Alelo de Deleção/Alelo de Inserção

Espalhamento Dinâmico de Luz

Ácido desoxirribose

Coeficiente de absortividade molar

Enzima Conversora de Angiotensina I

Ácido Etilenodiamino Tetra-Acético

Espectroscopia no Infravermelho com Transformada de Fourier

Hipertensão Arterial Sistêmica

Alelo de Inserção/ Alelo de Inserção

Caminho óptico

Dendrímero poli(amidoamina) Geração 4

Tampão Fosfato Salino

Reação em Cadeia da Polimerase

Reação em Cadeia da Polimerase em tempo real

Potencial Zeta

Transistor de Efeito de Campo de Porta Estendida e Separada

Sistema Renina Angiotensina Aldosterona

Tris EDTA

Microscopia Eletrônica de Transmissão

Tris(hidroximetil)aminometano

Espectroscopia no Ultravioleta-Visível 



\section{SUMÁRIO}

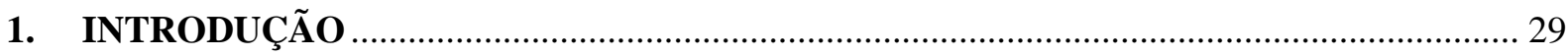

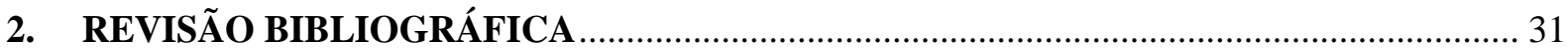

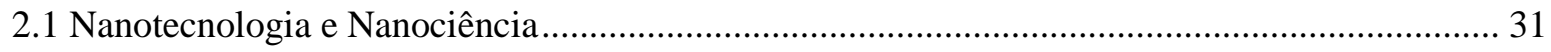

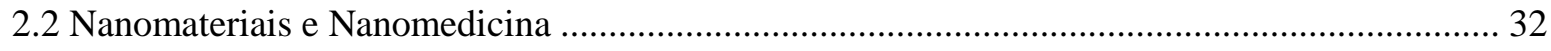

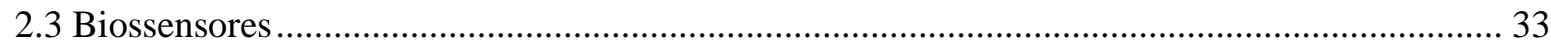

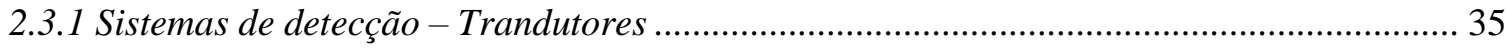

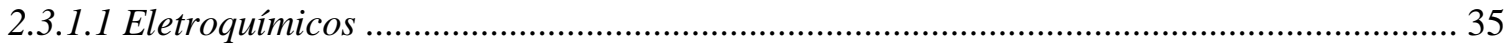

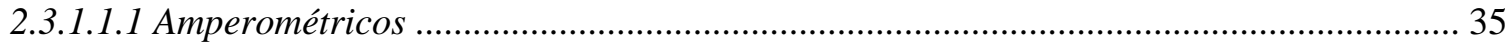

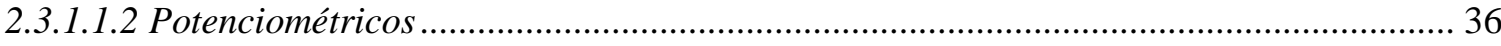

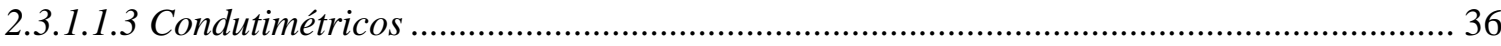

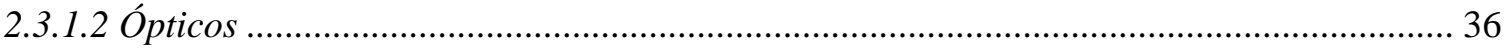

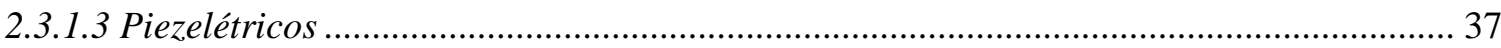

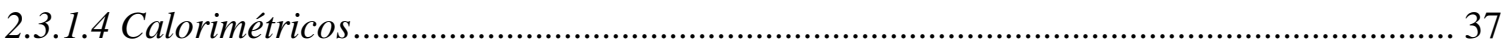

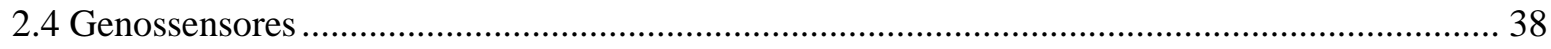

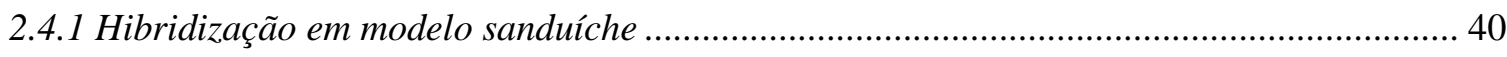

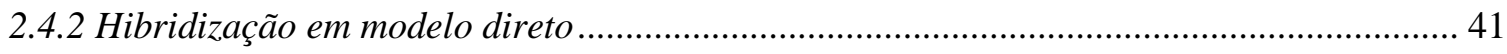

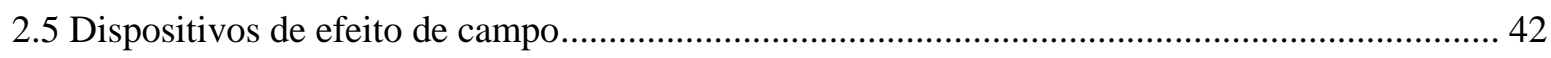

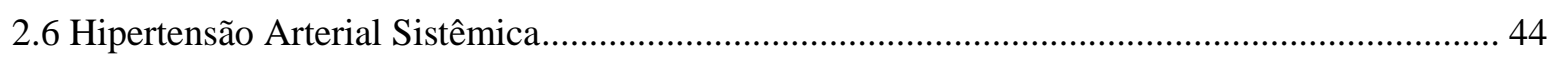

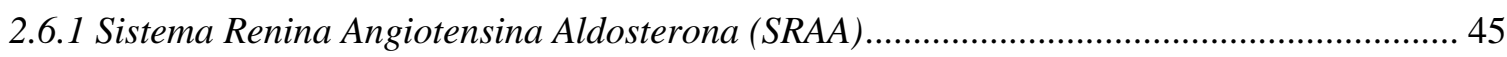

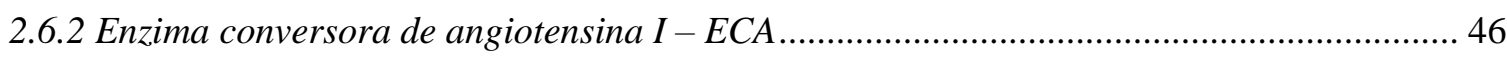

2.6.3 Diagnóstico para hipertensão arterial sistêmica ................................................................ 47

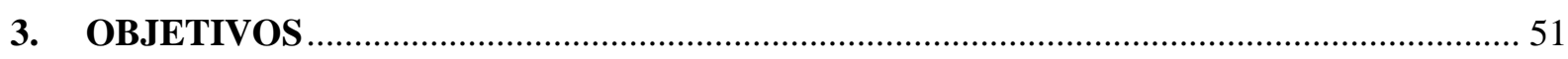

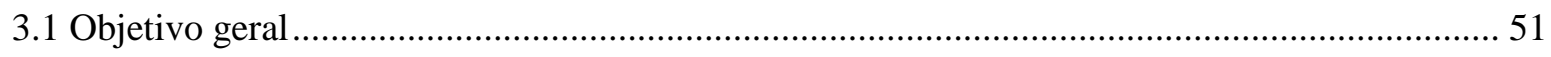

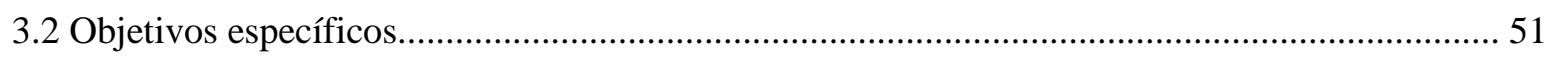

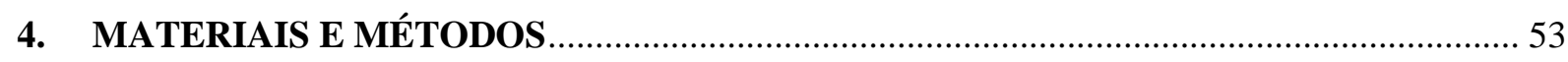

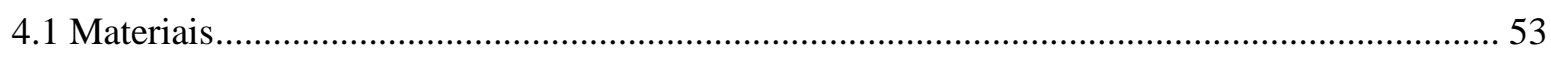

4.2 Estudo do conjugado AuNP-PAMAM/Oligonucleotídeo............................................................... 54

4.2.1 Síntese das nanopartículas de ouro estabilizadas em PAMAM-G4 ..................................... 54

4.2.2 Conjugação do oligonucleotídeo com as AuNP-PAMAM G4 ............................................. 56

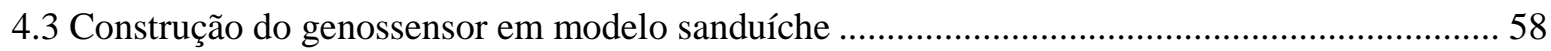

4.3.1 Imobilização do DNA na plataforma do genossensor elétrico .............................................. 59 
4.3.2 Imobilização do DNA na plataforma do genossensor eletroquímico 60

4.4 Construção do genossensor para caracterização em Transistor de Efeito de Campo de Porta

Estendida e Separada (SEGFET)... 61

4.4.1 Imobilização do DNA na plataforma do genossensor para caracterização em SEGFET ..... 61

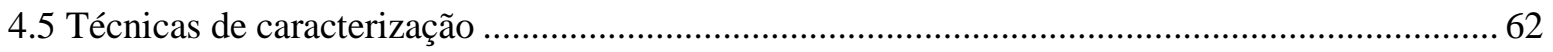

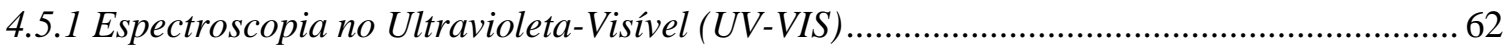

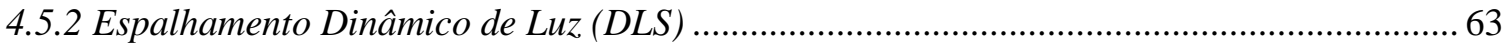

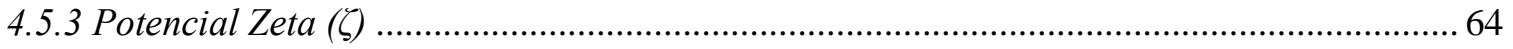

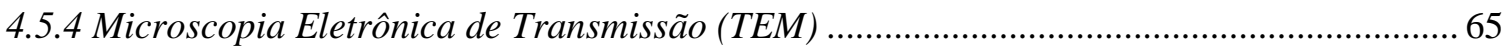

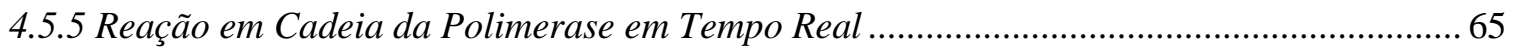

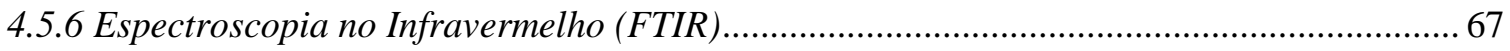

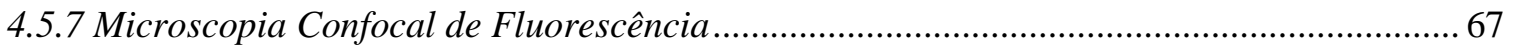

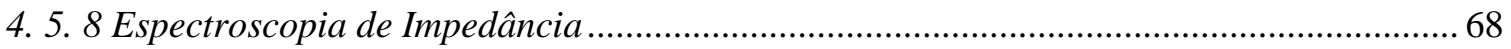

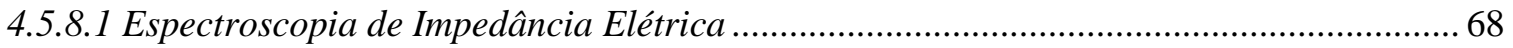

4.5.8.2 Espectroscopia de Impedância Eletroquímica ……........................................................... 71

4.5.9 Detecção em Transistor de Efeito de Campo de Porta Estendida e Separada (SEGFET) .. 73

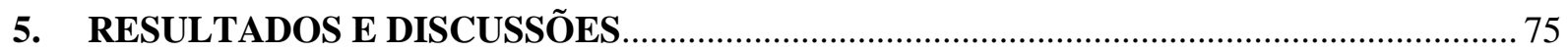

5.1 Síntese e caracterização das Nanopartículas de Ouro.................................................................... 75

5.2 Síntese e caracterização do conjugado AuNP-PAMAM G4/Oligonucleotídeo ............................. 77

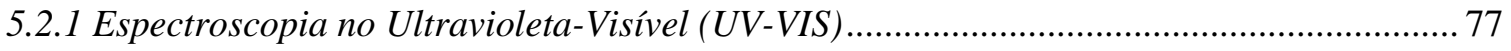

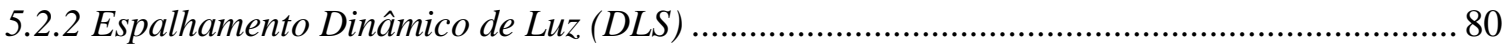

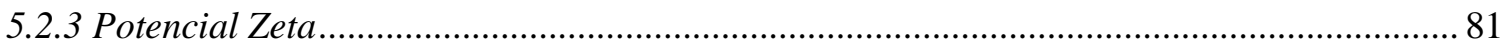

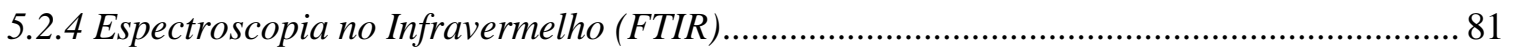

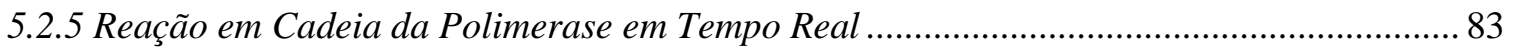

5.3 Desenvolvimento e caracterização do genossensor utilizando o AuNP-PAMAM

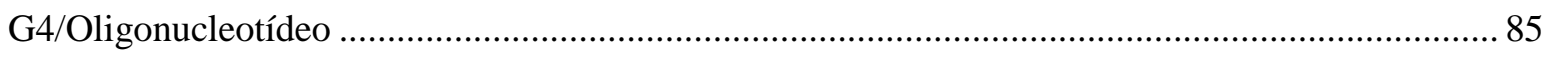

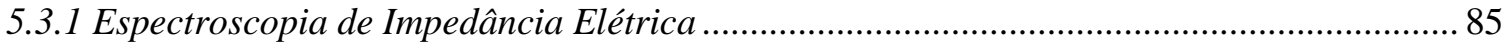

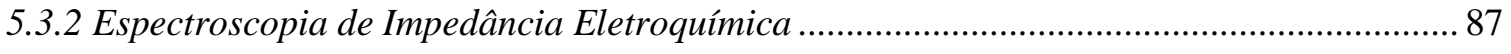

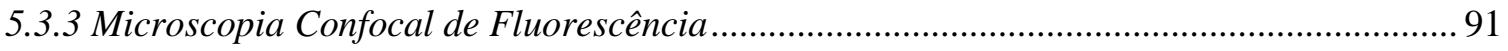

5.4 Desenvolvimento e caracterização do genossensor sem a utilização do AuNP-PAMAM

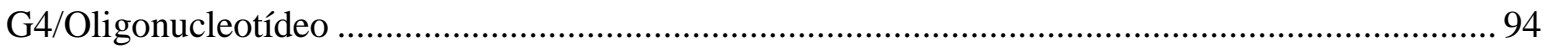

5.4.1 Detecção em Transistor de Efeito de Campo de Porta Estendida e Separada (SEGFET) .. 94

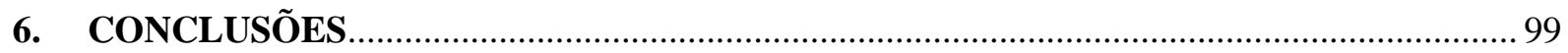

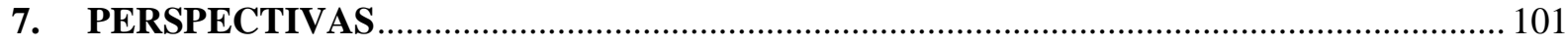

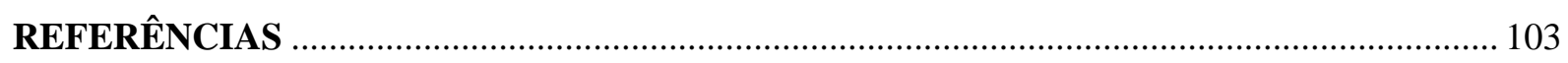

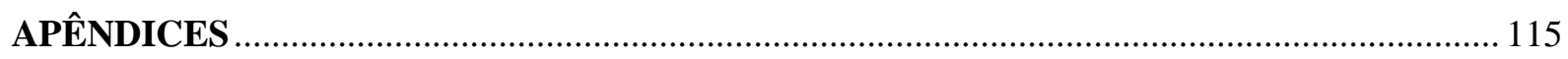


Apêndice A - Divulgação Científica e Tecnológica........................................................................... 115

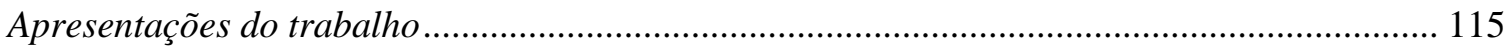

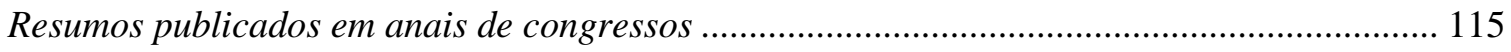

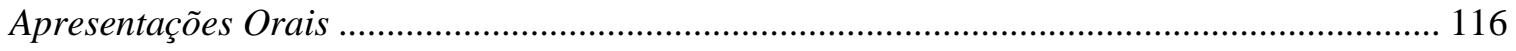

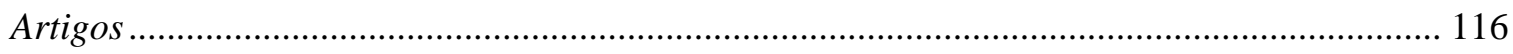

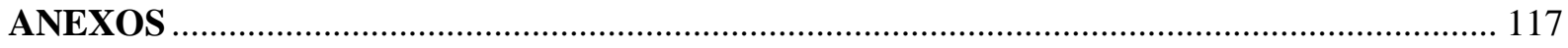

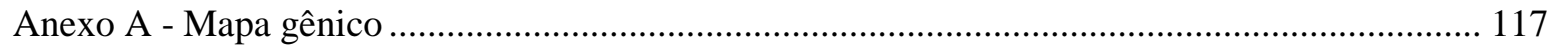





\section{INTRODUÇÃO}

A nanotecnologia e nanociência têm despertado grande interesse devido aos avanços que possibilitam à manipulação e caracterização dos materiais em escala nanométrica e, dessa maneira, permitem o domínio de propriedades específicas dos materiais. Do ponto de vista da medicina, em particular, a funcionalização de nanomateriais com biomoléculas tem sido amplamente utilizada na terapêutica e no diagnóstico de muitas patologias ${ }^{1-2}$. Destacando-se as nanopartículas, os nanofios e os nanotubos, que são empregados no melhoramento e otimização de biodispositivos convencionais. Esses nanomateriais aumentam a sensibilidade de biossensores, a estabilidade, a relação sinal/ruído, reduzindo o tempo de resposta, entre outros $^{3-4}$. Além disso, esses nanomateriais permitem um estudo em tempo real de interações celulares e moleculares em biossensores eletroquímicos ${ }^{5-6}$.

Um biossensor eletroquímico, de maneira geral, consiste de um eletrodo contendo uma espécie de reconhecimento, que podem ser espécies biológicas (anticorpos, enzimas, proteínas, receptores biológicos, DNA, entre outras), capazes de interagir com um meio complexo e de forma seletiva e específica, reagirem com seus respectivos alvos. $\mathrm{O}$ transdutor converte o sinal bioquímico em sinal de medida correspondente, de acordo com o princípio físico-químico de transdução ${ }^{7}$. Uma subcategoria dos biossensores muito analisada atualmente é o genossensor. Nos genossensores a espécie biológica imobilizada pode ser uma sequência pequena de DNA sintético ou genômico ${ }^{8}$. O biorreconhecimento ocorre por meio da hibridização com a sequência complementar no sentido antiparalelo ( $5^{\prime} \rightarrow 3^{\prime}$ e $\left.3^{\prime} \rightarrow 5^{\prime}\right)$. A arquitetura desse biodispositivo pode ser baseada em hibridização direta ou hibridização em modelo "sanduíche", na qual o produto final são três sequências de DNA hibridizadas, e o sinal de detecção é reportado de acordo com um marcador ${ }^{9}$.

A Hipertensão Arterial Sistêmica ${ }^{10}$ (HAS) é uma doença definida pela permanência de níveis de pressão arterial sanguínea acima de valores arbitrariamente definidos como normalidade. Em particular, representa sério problema de saúde pública, pela sua elevada prevalência, de $15 \%$ a $20 \%$ na população adulta e mais de $50 \%$ nos idosos. Além disso, junto com o tabagismo, diabetes e dislipidemia, constituem importante fator de risco para as doenças cardiovasculares, responsáveis por cerca de $30 \%$ das mortes ${ }^{11}$. O tratamento antihipertensivo tem como principal objetivo reduzir a morbidade e mortalidade cardiovasculares $^{11}$. No entanto, essa política de saúde tende a mudar com a aplicação da 
medicina preventiva, reduzindo não só os gastos com os tratamentos dos hipertensos, como também a prevalência dessa patologia na população. Saber se o individuo apresenta uma predisposição genética, para desenvolver hipertensão arterial sistêmica, ajudaria a protegê-lo de fatores ambientais que, associados aos genéticos, poderiam desencadear essa doença. A enzima conversora de angiotensina I - ECA - é uma metalopeptidase zinco-dependente cuja principal função é a homeostase da pressão arterial por meio da conversão da angiotensina I em angiotensina II $^{12}$. O polimorfismo de inserção e deleção - I/D, do gene ECA está associado a 47\% da variabilidade fenotípica das concentrações da ECA sérica, sendo as concentrações mais elevadas associadas à presença do alelo $\mathrm{D}^{13}$. A concentração de ECA elevada que o alelo D origina, leva a um quadro de predisposição à hipertensão arterial sistêmica. No entanto, os mecanismos moleculares não são totalmente conhecidos. Um dos eventos responsáveis é a constrição continua dos vasos sistêmicos e teciduais, que, a longo prazo, também favorece com o quadro de hipertensão arterial sistêmica crônica.

Nesse trabalho, apresentamos o desenvolvimento e estudo de um genossensor contendo nanopartículas de ouro estabilizadas com o dendrímero poli(amidoamina) geração 4, PAMAM G4, e funcionalizadas com o oligonucleotídeo desenhado especificamente para o polimorfismo I/D localizado no intron 16 do gene ECA. Os nanocompósitos foram caracterizados e aplicados no genossensor arquitetado em modelo sanduíche. As detecções foram realizadas pelas técnicas de espectroscopia de impedância elétrica e eletroquímica. Paralelamente a esse trabalho, foi desenvolvido outro genossensor estruturado com hibridização direta, no qual não foi aplicado o conjugado marcador, e nas etapas de detecção foi utilizado um transistor de efeito de campo de porta estendida e separada - SEGFET. 


\section{REVISÃO BIBLIOGRÁFICA}

\subsection{Nanotecnologia e Nanociência}

As teorias iniciais da nanotecnologia e nanociência foram propostas em 1959, em uma conferência na American Physical Society, no Instituto de Tecnologia da Califórnia, onde a palestra intitulada "There's plenty of room at the bottom" foi proferida pelo físico norteamericano Richard Feynman. Feynman sugeriu que os átomos poderiam ser organizados e rearranjados conforme a necessidade, desde que as leis da natureza não fossem violadas. Assim, materiais com propriedades inteiramente novas poderiam ser criados, visto que, apenas a escala de tamanho dos materiais já é capaz de alterar completamente suas propriedades. No entanto, hoje sabemos que não menos importante que o tamanho, mas também a forma, o arranjo, a orientação e as funcionalizações são de extrema importância na obtenção de novos materiais na escala nanométrica com outras utilidades e aplicações. Ainda, para que fosse possível a "visualização" de sua teoria, Feynman exemplificou dizendo que a enciclopédia britânica, com 24 volumes, caberia inteiramente escrita na cabeça de um alfinete. Pelo exposto, Richard Feynman propôs a construção de novos materiais e dispositivos átomo a átomo, molécula a molécula.

Entretanto, a aceitação na comunidade científica e os avanços reais em nanotecnologia só foram iniciados décadas depois, quando o microscópio de varredura por tunelamento (STM, do inglês Scanning Tunneling Microscope) e o microscópio de força atômica (AFM, do inglês Atomic Force Microscope) foram desenvolvidos ${ }^{14}$. Com esses microscópios a manipulação dos átomos e moléculas começou a ser possível. O primeiro nanomaterial, o fulereno, foi descoberto por Richard Smalley ${ }^{14}$ e o primeiro artigo científico relacionado com nanotecnologia foi publicado pelo autor Eric Drexler ${ }^{15}$, pesquisador do Instituto de Tecnologia de Massachusetts. Atualmente, existem vários equipamentos que possibilitam, além da manipulação e visualização de nanomateriais, a fina caracterização e o estudo detalhado das propriedades de superfície. A nanotecnologia e nanociência conquistaram pesquisadores em todo o mundo e um espaço generoso na comunidade científica com milhares de artigos científicos, patentes, projetos e bilhões em investimentos todos os anos. 


\subsection{Nanomateriais e Nanomedicina}

A mais recente definição para nanomateriais, proposta pela Comissão Europeia, abrange a normalização e padronização do termo e visa, em princípio, os riscos potenciais para a saúde, a segurança e os ambientes relacionados com os nanomateriais, dessa maneira ${ }^{16}$ : "Por nanomaterial entende-se um material natural, incidental ou fabricado, que contém partículas num estado desagregado ou na forma de um agregado ou de um aglomerado, e em cuja distribuição número-tamanho 50 \% ou mais das partículas têm uma ou mais dimensões externas na gama de tamanhos compreendidos entre $1 \mathrm{~nm}$ e $100 \mathrm{~nm}$ ”.

Com a mesma composição dos materiais em bulk e um tamanho extremamente reduzido, esses nanomateriais diferem por apresentarem a razão superfície/volume muitas ordens de grandeza maior, aumentando ou modificando dessa forma os efeitos que ocorrem na superfície, em relação às estruturas na escala maior. Assim, apresentam características como condutibilidade, reatividade e sensibilidade óptica, excepcionais, particulares à escala nanométrica $^{17-18}$.

Quando conjugados a moléculas biológicas como proteínas e DNA, os nanomateriais, em especial as nanopartículas, têm um grande potencial em medicina, em uma nova e promissora área denominada de nanomedicina. A nanomedicina contempla a utilização e o estudo de nanomateriais nas áreas da saúde, principalmente para diagnóstico e terapêutica, com aplicações desde nanocompostos capazes de liberar drogas de forma controlada, drug delivery, em células específicas, até cosméticos revitalizantes com nanopartículas, que tornam o acesso a derme muito mais fácil, passando também por nanoconjugados fotossensíveis que estão reescrevendo os diagnósticos por imagem ou tratamento de câncer ${ }^{19-20}$. As nanopartículas de ouro (AuNPs) e de óxido de ferro superparamagnéticas $\left(\mathrm{Fe}_{3} \mathrm{O}_{4}\right)$ apresentam uma ótima estabilidade, são de fácil preparo e funcionalização química, sendo assim as mais estudas e utilizadas. Além disso, se encontram entre as mais promissoras para diagnosticar e tratar o câncer, sendo o uso do ouro aprovado pelo FDA (Food and Drug Administration) ${ }^{21}$ para algumas aplicações terapêuticas. Estas nanopartículas já são usadas para fins diagnósticos, na detecção de imagens de tumores por tomografia ${ }^{22-23}$. Por exemplo, nanopartículas superparamagnéticas de óxido de ferro $\left(\mathrm{Fe}_{3} \mathrm{O}_{4}\right)$ estão sendo utilizadas para manipular a maquinaria celular de neurônios. Com o aquecimento local gerado pela aplicação de um campo magnético nessas nanopartículas, os canais de íons localizados nas membranas das células são capazes de aumentar seus potenciais elétricos, ativando desta forma funções celulares essenciais ${ }^{20}$. 
As nanopartículas de ouro apresentam propriedades ópticas excepcionais. Quando essas partículas são submetidas a luz, pode ocorrer acoplamento de forma ressonante, com os elétrons livres do metal, e seus elétrons condutores produzem coletivamente uma oscilação. Essas oscilações são denominadas de "plasma de superfície" e são dependentes do tamanho e forma da nanopartícula, da constante dielétrica do meio, e da distância entre as partículas ${ }^{5,24}$. Além do uso destas nanopartículas para o diagnóstico e terapia do câncer, nanopartículas de ouro, quando conjugadas com DNA, são utilizadas em dispositivos como marcadores ativos na detecção de mutações e polimorfismos, caracterizando avançados diagnósticos moleculares para muitas patologias com carga genética ${ }^{2}$. Além da manipulação e imobilização na forma de filmes finos, que são essenciais para sua utilização em dispositivos biotecnológicos. Sendo esses de extrema importância para aplicações em biomedicina.

Em oncologia, os nanobioconjugados possuem ampla aplicação em processos e sistemas biotecnológicos para otimizar a procura de novos biomarcadores, diagnóstico molecular, e melhorar a biodisponibilidade de medicamentos ${ }^{25}$. A investigação dos mecanismos de interação de nanopartículas com biomoléculas se tornou essencial para a criação de novos nanobiocompostos que possam ser aplicados à problemática em saúde de várias patologias, dentre elas, o câncer, doenças infecciosas, cardiovasculares, hipertensão arterial, entre outras ${ }^{2,26-28}$. Estas doenças afetam grande parte da população mundial e brasileira, representando grandes gastos públicos no setor de saúde. Com os nanomateriais a medicina poderá implantar sua base preventiva, e, dessa forma, além de aumentar a qualidade e a expectativas de vida, diminuir os gastos no setor de saúde.

\subsection{Biossensores}

A International Union of Pure and Apllied Chemistry - IUPAC propôs uma definição para biossensor $^{32}$ :

"Um biossensor é um instrumento integrado que é capaz de fornecer uma informação analítica específica quantitativa ou semi-quantitativa através do uso de um elemento de reconhecimento biológico (receptor bioquímico) que esta em contato direto com o elemento transdutor."

Os biossensores podem ser definidos como dispositivos analíticos que apresentam espécies moleculares biológicas imobilizadas em um transdutor. Essas espécies moleculares são denominadas de biorreceptores e utilizam um mecanismo bioquímico para 
reconhecimento. O biorreconhecimento ocorre por meio de interações antígeno-anticorpo, interações enzimáticas, molécula-alvo e seu receptor, ou aquelas entre ácidos nucleicos, como é o caso de sequências complementares no sentido antiparalelo $\left(5^{\prime} \rightarrow 3^{\prime}\right.$ e $\left.3^{\prime} \rightarrow 5^{\prime}\right)$. O funcionamento de um biossensor ocorre pela parte ativa do sensor, ou seja, pelo elemento de reconhecimento biológico imobilizado e o transdutor, esquematizado na Figura 1. A interação que ocorre entre o elemento imobilizado e o analito pode promover uma reação, entre outros fatores, que causa uma variação na concentração de prótons, liberação de gases, emissão ou absorção de luz, emissão de calor, variação de massa, mudança de estado de oxidação, entre outras. Posteriormente a alteração no sistema, o transdutor converte a variação em uma resposta mensurável podendo ser: corrente, potencial, variação de temperatura, entre outras ${ }^{29}$.

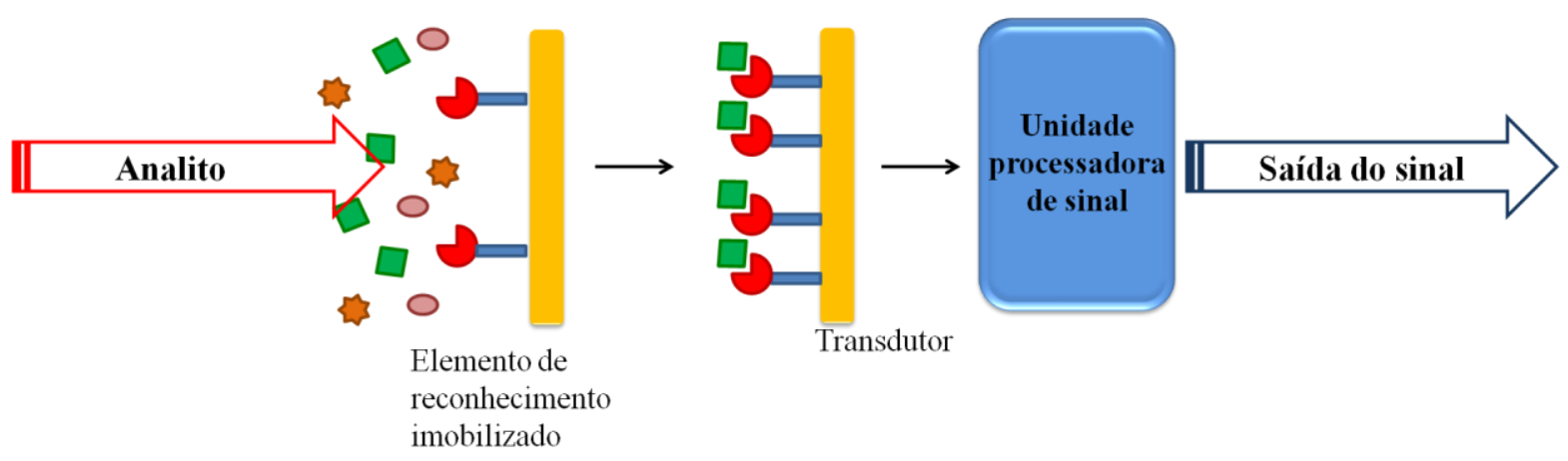

Figura 1 - Esquema de funcionamento de um biossensor.

Os bissensores podem ser classificados de acordo com o elemento molecular imobilizado como: enzimáticos, microbiológicos, imunossensores, genossensores, entre outros. Outra forma de classificação dos biossensores é representada pelo sistema de transdução utilizado. Desta forma, os biossensores podem ser classificados em: eletroquímicos (amperométricos, potenciométricos e condutimétricos), ópticos, piezelétricos ou calorimétricos ${ }^{30}$. 


\subsubsection{Sistemas de detecção - Trandutores}

\subsubsection{Eletroquímicos}

Os transdutores eletroquímicos são baseados no movimento de íons e na difusão de espécies eletroativas ${ }^{31}$. Os biossensores que utilizam esses transdutores são mais utilizados, quando comparados aos biossensores ópticos e calorimétricos, pois são estáveis, apresentam screening rápido, alta sensibilidade, possuem a grande vantagem de serem econômicos e a possibilidade de automação, permitindo sua aplicação em um grande número de amostras ${ }^{30,32}$. São utilizados também em análises clínicas e testes de monitoramento ${ }^{33-35}$. No entanto, é necessário cautela para a utilização, pois são sensíveis a alterações de temperatura, força iônica e pH. Além disso, são vulneráveis a ruído elétrico, necessitam de eletrodos de referência estáveis, podem apresentar adsorção de forma não seletiva e bloqueio da superfície do sensor. Eles podem ser classificados de acordo com os parâmetros aplicados, sendo: amperométricos, potenciométricos ou condutimétrico ${ }^{33-34}$.

\subsection{Amperométricos}

O princípio de funcionamento de um transdutor amperométrico é baseado na medida da corrente produzida por uma reação química entre espécies eletroativas, susceptíveis a oxidação ou redução no eletrodo. Esse eletrodo é colocado em um potencial fixo em relação a um eletrodo de referência. Assim, mede-se a transferência de elétrons do analito para o eletrodo ou do eletrodo para o analito. A medida ocorre de acordo com a corrente elétrica resultante das variações de oxidação ou redução eletroquímica por meio da espécie eletroativa presente na solução. A direção do fluxo de elétrons é dependente das características do analito. ${ }^{36-37}$. É possível estimar a concentração do analito e do produto por meio da corrente produzida pela reação redox, visto que, elas são linearmente proporcionais. 


\subsection{Potenciométricos}

Os transdutores potenciométricos são baseados na determinação da diferença de potencial entre o eletrodo e um eletrodo de referência. Normalmente são utilizados eletrodos de gases ou eletrodos íons seletivos. Ainda existem sistemas com dois eletrodos de referência separados por uma membrana permeável seletiva, em que não há fluxo de corrente significativa entre eles. Os eletrodos ficam em contato direto com a amostra e a diferença de potencial acontece por um aumento das cargas na superfície do eletrólito. Os eletrodos de íons seletivos são capazes de detectar tais alterações e transformá-las em sinal mensurável ${ }^{37}$.

\subsection{Condutimétricos}

Os transdutores condutimétricos são fundamentados nas medidas de alterações da condutância. Biossensores que utilizam esses transdutores associam enzimas catalíticas que durante as reações consomem ou produzem espécies iônicas, dessa forma, alteram a condutividade da solução. É possível estimar a concentração iônica por meio da condutividade, porém, não é possível saber qual o elemento iônico presente ${ }^{36,38}$. O funcionamento é baseado em um par de microeletrodos imersos em uma solução eletrolítica, que contem uma enzima. Na presença do analito é aplicado um potencial nos microeletrodos, e a análise é baseada nas variação da concentração de espécies polarizadas ${ }^{38}$.

\subsubsection{2 Ópticos}

O princípio de funcionamento de um transdutor óptico é a interação entre espécies biológicas imobilizadas ou reações químicas que promovam alteração nas propriedades ópticas. Essas alterações em determinadas substâncias modificam a luz observada, ou a resposta quando iluminada, e podem ser transmitidas por meio de fibras ópticas que conduzem as ondas de luz a detectores apropriados em equipamentos ópticos ${ }^{37}$. Os métodos ópticos com transdução física são muito utilizados em análises bioquímicas por serem 
bastante confiáveis e variados, tais como, absorção, fluorescência, fosforescência, polarização e interferência. Além disso, podem ser utilizados em sensores de estados sólidos, associados a uma espécie biológica imobilizada, com um indicador ou não ${ }^{37}$.

\subsubsection{Piezelétricos}

Os transdutores piezelétricos são fundamentados nas análises de alterações de massa ou microviscosidade, de onda de cisalhamento, ou de superfície acústica ${ }^{31,37}$. Na superfície do biossensor é imobilizada uma molécula biologicamente ativa e, posteriormente, aplicada em uma solução contendo o alvo, que interage com a molécula imobilizada aumentando a massa do cristal e diminuindo proporcionalmente a frequência de ressonância das oscilações ${ }^{33-34}$. Os cristais de quartzo são muito sensíveis às variações de massa e sua frequência de trabalho é na faixa megahertz. Dessa maneira, são muito usados em sistemas de transdução piezelétricos. $\mathrm{O}$ sensor denominado microbalança de cristal de quartzo (QCM, do inglês Quartz Crystal Microbalance) exibe alta sensibilidade e detecta todas as alterações de nanogramas que podem ocorrer, quando o alvo interage com a molécula no transdutor ${ }^{39}$.

\subsubsection{Calorimétricos}

Os transdutores calorimétricos também podem ser chamados de termistores ${ }^{37}$, e são fundamentados na variação de entalpia do sistema. É possível detectar substâncias baseadas apenas no calor envolvido nas reações químicas do analito com a sua substância biológica ativa. As substâncias são imobilizadas diretamente no sensor, que detecta o calor envolvido na reação química, sendo possível quantificar o substrato consumido ou o produto formado pela reação ${ }^{38}$. No entanto, parte do calor é trocado com o ambiente, na reação de mistura e no efeito de solvatação, assim, inevitavelmente, erros de análise podem ocorrer diminuindo a sensibilidade dos biossensores calorimétricos ${ }^{33-34}$. 


\subsection{Genossensores}

Os genossensores são dispositivos analíticos avançados, que exibem a promessa de diagnósticos com elevada especificidade e sensibilidade, são de baixo custo e podem ser utilizados para a detecção precoce de muitas patologias genéticas ${ }^{40}$. De maneira geral, são sensores de DNA e podem ser arquitetados para detectar qualquer sequência de DNA. Um sensor de DNA apresenta uma ou mais sequências pequenas de DNA, entre 20 a 40 pares de bases, imobilizadas em uma plataforma apropriada. A imobilização das sequências de DNA na plataforma pode ser realizada promovendo uma modificação específica em uma das extremidades da sequência ( $5^{\prime}$ ou 3'), ou com a ligação de um linker bifuncional, que se liga na plataforma e na extremidade da sequência do DNA, que apresenta a modificação, simultaneamente $^{41}$. O biorreconhecimento acontece pela hibridização com o DNA alvo (complementar) nas etapas de detecção. O sinal detectado pode ser elétrico, fluorescente, eletroquímico, calorimétrico, entre outros, (Figura 2).

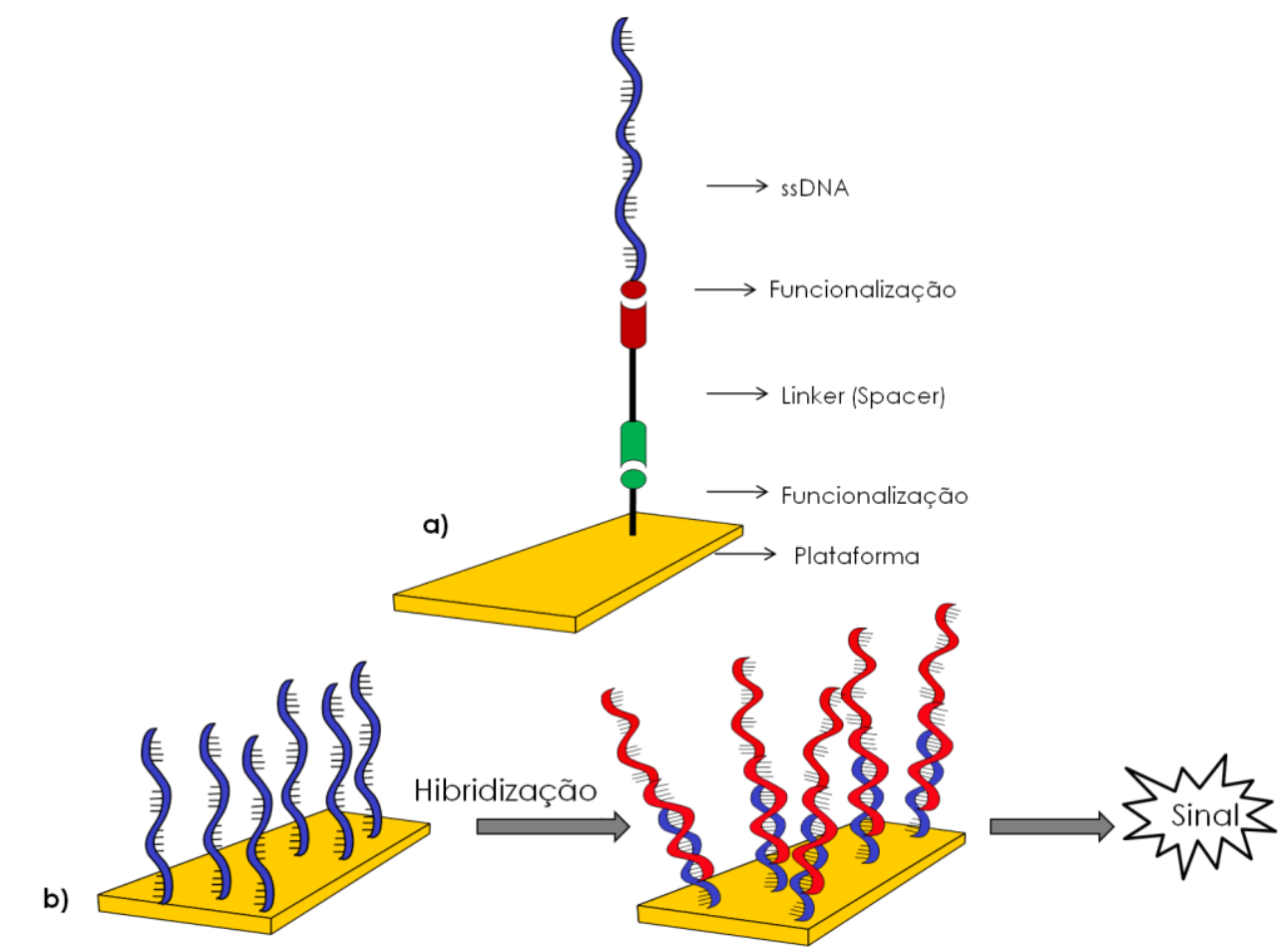

Figura 2 - Esquema de um sensor de DNA. Imobilização das sequências de DNA, onde um linker (spacer) bifuncional é utilizado para ancorar o DNA na plataforma (a). Funcionamento de um sensor de DNA: sequências imobilizadas $\rightarrow$ hibridização $\rightarrow$ captura do sinal (b).

O ácido desoxirribonucleico (DNA, do inglês deoxyribonucleic acid) é um biopolímero composto por monômeros, nucleotídeos, formados por um grupo fosfato, uma 
pentose (desoxirribose) unidos por ligações fosfodiéster e associados a uma das quarto bases nitrogenadas (adenina, timina, citosina ou guanina). Em sequência, representam em formato de código, a informação genética (Figura 3$)^{42}$. Essa informação pode conter mutações ou polimorfismos genéticos. As mutações são erros permanentes na sequência de DNA, que quando codificada expressa alguma proteína não funcional, ou com função alterada, ou ainda, não expressa nenhuma proteína. Os polimorfismos são a ocorrência simultânea em uma mesma população, de formas diferentes de um mesmo gene, ou sequência não codificadora de DNA, e estão presentes em mais de $1 \%$ na população ${ }^{127}$.

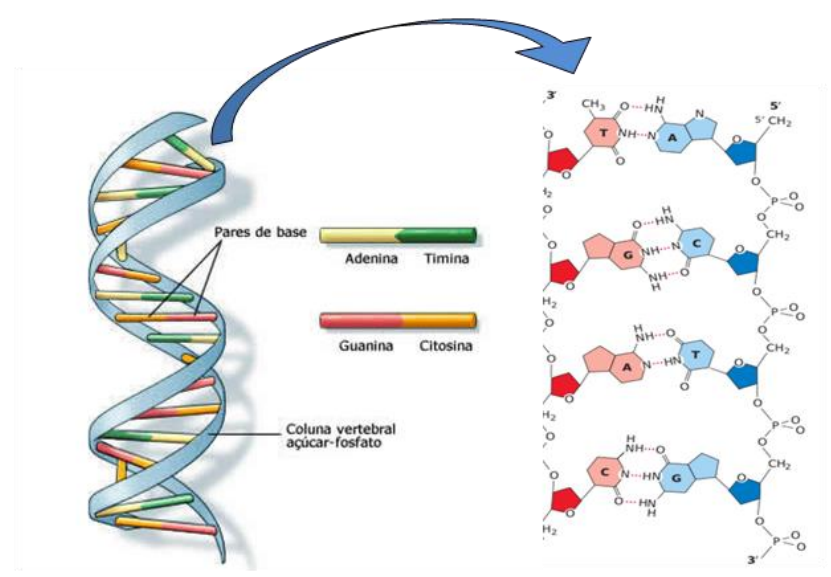

Figura 3 - Esquema da molécula de DNA em conformação de dupla hélice. Estruturada pelo grupo fosfato ligado na pentose, ligação fosfodiéster, juntos representam o "esqueleto" molecular do DNA. A hibridização com a sequência complementar ocorre pelas bases nitrogenadas (adenina, timina, citosina ou guanina). As purinas (adenina e guanina) hibridizam apenas com as pirimidinas (timina e citosina) e sempre de maneira a manter a mesma distância entre as duas fitas na sequência toda. Assim, a guanina apenas se liga na citosina e a timina apenas na adenina ${ }^{42}$.

Alguns trabalhos recentes com genossensores têm reportado a detecção de uma única base não complementar em pequenas sequências de DNA, como detalhado por Chatelain et $a l .{ }^{43}$. Podemos citar também, a criação de um genossensor para detecção do patógeno Aeromonas hydrophila com hibridização de DNA utilizando voltametria cíclica ${ }^{44}$. Bonanni et al. relatam a detecção de um polimorfismo do DNA relacionada com fibrose cística em eletrodos de carbono modificado, utilizando um dispositivo eletroquímico ${ }^{45}$. Em um estudo recente, Civit et al. mostraram a detecção simultânea de múltiplos vírus do papiloma humano (HPV) com sequências de DNA. Este sensor apresentou alta eficiência na detecção ${ }^{46}$. Ainda, pesquisadores desenvolveram um genossensor utilizando hibridização direta para detectar mutações do gene BRCA1 (do inglês, Breast Cancer 1) que estão relacionadas com o câncer de mama, por ser um gene supressor de tumores que controla o ciclo celular e a proliferação celular descontrolada ${ }^{47}$. Ali et al., estudaram um genossensor baseado em espectroscopia de 
impedância eletroquímica para leucemia linfocítica crônica, e utilizaram como plataforma eletrodos de ouro modificados com nanopartículas de ouro. Esse nanossensor foi capaz de diferenciar uma única base diferente na sequência, ou mismatch ${ }^{48}$. So-Jung et al. reportaram um sensor de DNA que utiliza recobrimento das nanopartículas de ouro por prata. Estes nanoconjugados preenchem a distância entre as trilhas de ouro do eletrodo, alterando a condutividade elétrica. Usando este método, os autores conseguiram detectar DNA alvo em concentrações muito baixas como $500 \mathrm{fM}$ com uma seletividade de mutação de ponto, com um fator de, aproximadamente, 100.000:19 . Pesquisadores analizaram um teste baseado também em sequências de DNA para detectar por meio de técnicas eletroquímicas sequências do vírus que causa a Síndrome Respiratória Aguda Grave (SARS, do inglês Severe Acute Respiratory Syndrome) que pode levar a óbito em poucos dias ${ }^{50}$.

O conceito dos genossensores pode revolucionar os estudos genéticos e os diagnósticos biomoleculares, tornando-os mais acessíveis, mais específicos, e com detecção quase instantânea. Assim, apresentam um grande potencial na medicina preventiva e podem ser utilizados em muitas patologias evitando a cronicidade e até mesmo o seu desenvolvimento. Uma forma de classificação dos genossensores é o modelo de hibridização utilizado na arquitetura do sensor. Dessa maneira geral, eles podem ser classificados em modelo de sanduíche ou em modelo de hibridização direta.

\subsubsection{Hibridização em modelo sanduíche}

A hibridização é a ligação de dois fragmentos de DNA em condições específicas e adequadas para cada sequência, e essas condições são baseadas na composição das bases nitrogenadas que a sequência apresenta. As condições essenciais para que ocorra hibridização específica são a complementaridade no sentido antiparalelo ( $5^{\prime} \rightarrow 3^{\prime}$ e $\left.3^{\prime} \rightarrow 5^{\prime}\right)$. Além disso, os tipos de sais e as suas concentrações no tampão que será utilizado na reação também são parâmetros para o sucesso no processo de hibridização. O modelo de hibridização sanduíche ${ }^{40}$ consiste em duas hibridizações consecutivas, na qual o produto final será a sequência analisada de DNA proveniente da amostra, entre duas sondas de DNA, uma imobilizada na plataforma (eletrodo), e a outra com um marcador na extremidade (5' ou 3') da sequência, semelhante à estrutura de um sanduíche (Figura 4$)^{9}$. O sinal de detecção deriva da segunda 
hibridização, realizada ou não por temperatura específica, que pode provocar alguma alteração no sistema e no marcador presente.

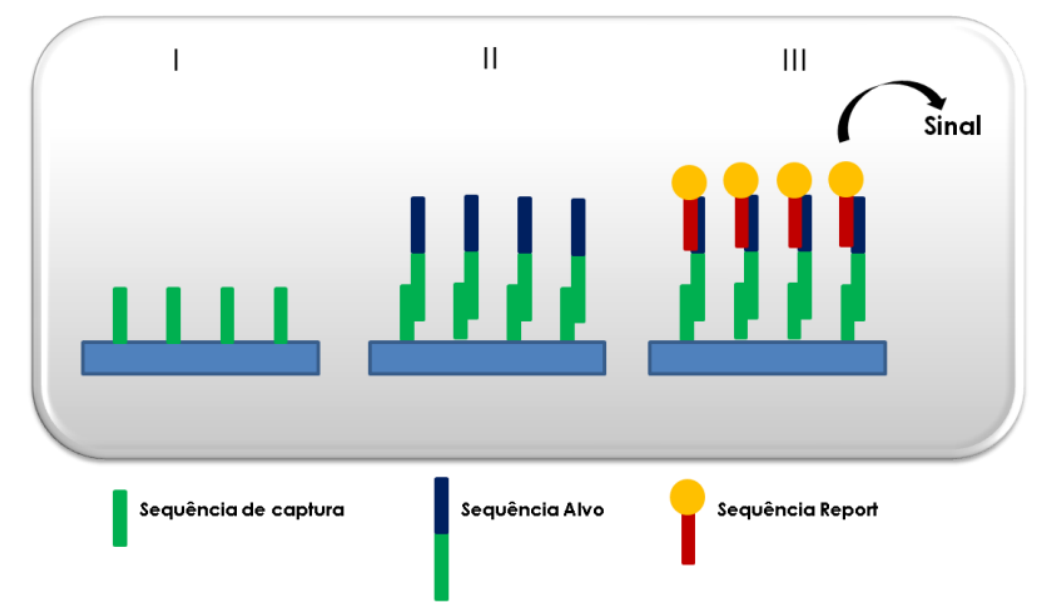

Figura 4 - Estratégia para detectar sequências complementares de DNA alvo em genossensores com formato de hibridização tipo sanduíche. I) Ancoragem da sequência de captura; II) Imobilização da sequência alvo complementar ( $1^{a}$ hibridização); III) Hibridização da sequência repórter, contendo um marcador na parte superior, com a sequência alvo ( $2^{\mathrm{a}}$ hibridização).

\subsubsection{Hibridização em modelo direto}

O modelo de hibridização em formato direto, também empregado em genossensores, é simples e como o próprio nome sugere, é direto, sem a presença de uma terceira sonda no sistema, como ocorre no modelo em formato tipo sanduíche. No modelo de hibridização direta uma sonda de DNA é imobilizada na plataforma e acontece apenas uma hibridização direta com o DNA alvo, podendo esse apresentar um marcador ou não (Figura 5) ${ }^{8-9}$. O sinal de detecção deriva dessa única hibridização, que pode provocar alguma alteração no sistema, ou no marcador, quando presente. 


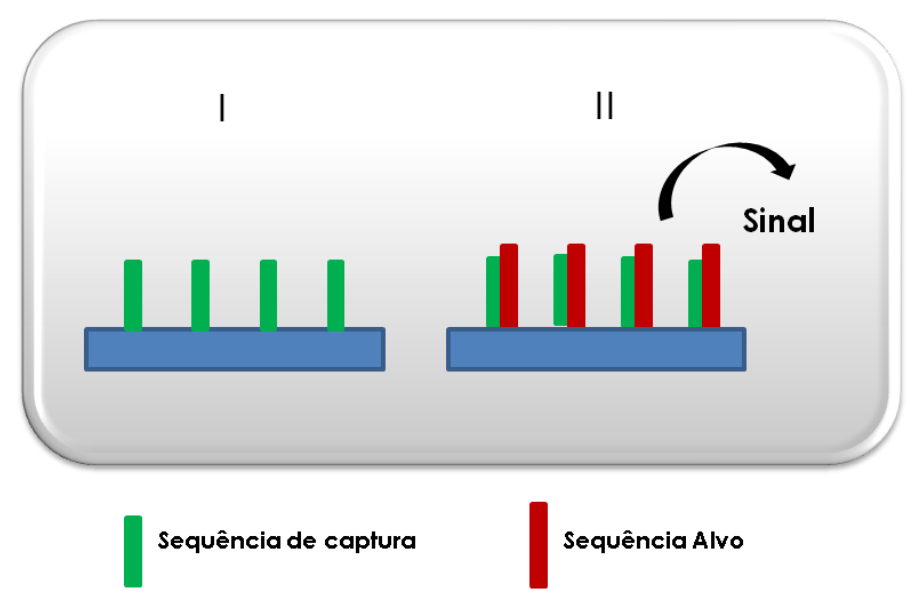

Figura 5 - Estratégia para detectar sequências complementares de DNA alvo em genossensores com formato de hibridização direta. I) Ancoragem da sequência de captura; II) Hibridização com a sequencia alvo complementar e captura do sinal.

\subsection{Dispositivos de efeito de campo}

Como abordado anteriormente, em genossensores convencionais, sequências espécíficas de DNA são imobilizadas em um suporte sólido, hibridizadas com o DNA alvo e o sinal de detecção é originário de uma terceira sequência geralmente conjugada com um marcador ${ }^{9}$. Entretanto, existe a possibilidade de detectar de forma direta o processo de hibridização de sequências DNA (sem necessidade de uma terceira fita contendo nanopartículas ou marcadores, utilizando, por exemplo, dispositivos de efeito de campo (FEDs, do inglês Field-Effect Devices) ${ }^{51}$.

Existem vários tipos de dispositivos FED para diversas aplicações, incluindo o transistor de efeito de campo sensível a íons (ISFET) ${ }^{52}$, o sensor capacitivo eletrólito-isolantesemicondutor $(E I S)^{53}$, o sensor potenciométrico ativado por luz (LAPS) ${ }^{54}$, o transistor de efeito de campo de porta estendida $\left(\text { EGFET) }{ }^{55} \text { ou de porta estendida e separada (SEGFET) }\right)^{56}$. Todos esses dispositivos operam modulando o sinal de saída (corrente ou tensão), devido a uma alteração do campo elétrico na membrana sensível em virtude da alteração da concentração iônica de uma solução ${ }^{51}$.

O ISFET é o tipo mais comum de FED utilizado como sensor iônico, porque pode ser miniaturizado e fabricado em larga escala. A Figura 6 mostra o diagrama esquemático de um ISFET que na verdade é um MOSFET (transistor de efeito de campo metal-óxido semicondutor) modificado. A diferença entre os dispositivos se refere à inexistência do 
eletrodo metálico de porta no ISFET, sendo este substituído por um eletrodo de referência e uma solução eletrolítica em contato com o óxido da região de porta (membrana sensível).

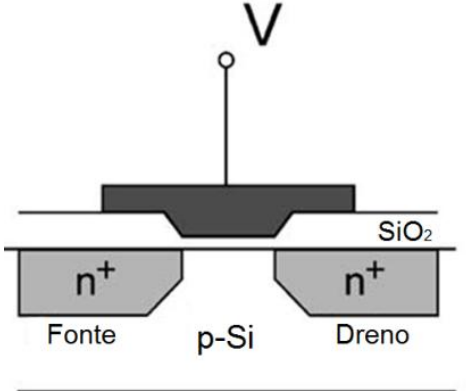

(a) MOSFET

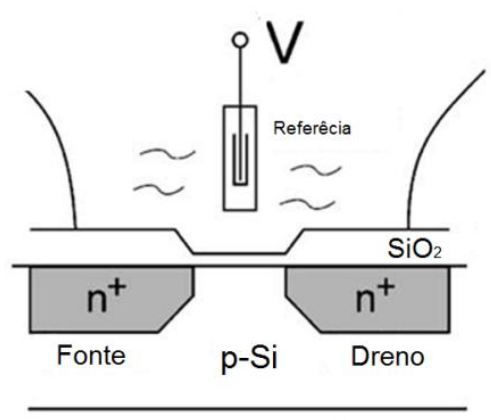

(b) ISFET

Figura 6 - Diagrama esquemático de um MOSFET (a) e de um ISFET (b) ${ }^{52}$.

As aplicações no campo biomédico se dão pela imobilização de materiais de origem biológica na porta de um ISFET. Os chamados ENFETs (FETs enzimáticos) utilizam uma enzima imobilizada na porta do dispositivo, atuando portanto como biossensores ${ }^{57}$. Por outro lado, os imunoFETs são construídos por meio da imobilização de antígenos ou anticorpos na porta de um ISFET $^{58}$, e a alteração de carga na porta devido a interação antígeno-anticorpo permite a aplicação desse dispositivo no campo imunológico ${ }^{58}$. Quando o material imobilizado é uma sequência de DNA, o ISFET pode ser aplicado para a detecção da sonda de DNA complementar ${ }^{51}$. O princípio de detecção de DNA utilizando o ISFETs baseia-se no aumento da densidade de carga quando a sonda de DNA imobilizado se hibridiza com o respectivo DNA alvo, formando uma dupla fita ${ }^{51}$.

Como pode ser observado na Figura 6, no ISFET, a parte transdutora está em contato direto com a solução, o que pode comprometer a análise e dificultar o setup experimental. Além disso, a imobilização de biomoléculas em um supote de dimensões pequenas pode ser outro inconveniente. Portanto, neste trabalho, optamos por utilizar uma variação do ISFET, nesse caso, o dispositivo é formado por uma membrana sensível ligada ao eletrodo de porta de um MOSFET ${ }^{55,59}$ comercial e recebe o nome de transistor de efeito de campo de porta estendida e separada (SEGFET, do inglês separative extended gate field effect transitor) (Figura 7). De forma análoga a um ISFET, uma alteração do potencial de superfície modula a corrente dreno-fonte do MOSFET ${ }^{55,59}$. Quando comparado ao ISFET, o processo de medida de um SEGFET é mais simples, a imobilização de biomoléculas é facilitada e as etapas de fabricação do dispositivo se restringe a simples manipulação da porta estendida. O MOSFET 
comercial pode ser reaproveitado para novas aplicações e a parte sensível pode se utilizada de forma descartável, o que é desejado em aplicações biomédicas.

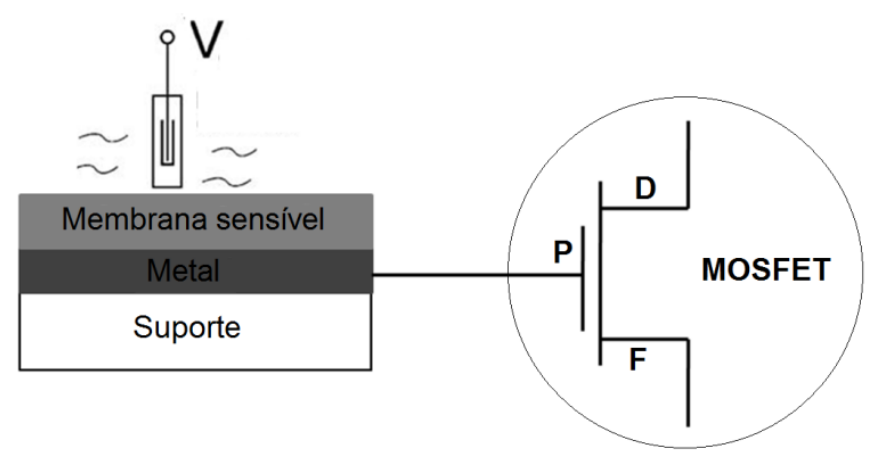

Figura 7 - Diagrama esquemático de um SEGFET. P, F e D representam, respectivamente, os eletrodos porta, fonte e dreno, de um MOSFET comercial.

\subsection{Hipertensão Arterial Sistêmica}

A Hipertensão Arterial Sistêmica ${ }^{10}$ (HAS) é uma doença definida pela persistência de níveis de pressão arterial acima de valores arbitrariamente definidos como limites de normalidade. Pelas atuais diretrizes, a HAS consiste em um fator independente de risco a muitas outras patologias. Dessa forma, a HAS pode ser considerada como uma síndrome, pois promove alterações hemodinâmicas, tróficas e metabólicas, envolvendo dislipidemias, resistência insulínica, obesidade centrípeta, microalbuminúrica, atividade desregulada dos fatores de coagulação, entre outras. A hipertensão está intimamente relacionada a diversas doenças cardíacas, coronarianas, cerebrovasculares, renais e vasculares, o que aumenta muito a sua morbimortalidade. Assim, há um aumento considerável nos custos humanos e médicos decorrentes dessas consequências ${ }^{10}$. A hipertensão arterial e as doenças relacionadas são responsáveis por alta frequência de internações, sendo a insuficiência cardíaca a principal causa de hospitalização entre as doenças cardiovasculares, sendo ainda responsável pelo dobro de internações em relação ao acidente vascular cerebral ${ }^{12}$.

Sendo a HAS uma doença poligênica e de causa multifatorial, constitui um grave problema de saúde pública, afetando 30 milhões de indivíduos, somente no Brasil ${ }^{60}$. Estudos indicam que, em 2025 , quase $30 \%$ da população mundial poderá apresentar essa doença ${ }^{61}$. No 
ano 2000, 15\% das internações no sistema único de saúde (SUS), em indivíduos entre 30 e 69 anos, ocorreram por doenças cardiovasculares no Brasil, destes, aproximadamente 110 mil casos foram relacionados ao acidente vascular cerebral e ao infarto agudo do miocárdio, doenças em que a hipertensão arterial desempenha um papel agravante como fator de risco ${ }^{62}$. Em 2003, 27,4\% de todos os óbitos ocorreram por doença cardiovascular e, excluindo-se as mortes violentas e de origem não definida, este índice sobe para 37\%. A HAS está envolvida em $40 \%$ das mortes por doença cerebrovascular e em $25 \%$ das mortes por doença coronariana. Em 2005, ocorreram mais de 1.180 .000 internações por doenças cardiovasculares, com custo global de mais de um bilhão e trezentos milhões de reais ${ }^{63}$.

A importância da HAS como relevante fator de risco cardiovascular, alta prevalência mundial e aumento da probabilidade de desfechos circulatórios, fatais ou não-fatais, quando a ela estão associados outros fatores de risco, tornam muito importante o conhecimento da sua possível ocorrência na população ${ }^{64}$. Idade, etnia, consumo excessivo de sal, obesidade, sedentarismo, estresse, resistência à insulina, ingestão aumentada de álcool, entre outros, são alguns dos fatores relacionados ao aparecimento e à cronicidade da $\operatorname{HAS}^{10}$.

\subsubsection{Sistema Renina Angiotensina Aldosterona (SRAA)}

O Sistema Renina Angiotensina Aldosterona (SRAA) é um sistema neuroendócrino conjugado, responsável pela modulação do equilíbrio hidroeletrolítico e regulação da pressão arterial sistêmica pelo seu processo de homeostase. Os eventos promovidos por meio desse sistema resultam em um efeito protetor ao tecido endotelial, cardíaco, cerebral e renal ${ }^{65}$.

Esse sistema funciona por meio de uma cascata de eventos os quais levam a um equilíbrio hidroeletrolítico controlando a pressão arterial sistêmica (Figura 8). Quando o individuo se encontra com uma hipotensão, a perfusão tecidual diminui, assim a perfusão dos rins também é afetada, e, por meio de um feedback negativo, os rins liberam e começam a sintetizar a renina, enzima que cliva o angiotensinogênio em angiotensina I. Nos pulmões e nos rins, a angiotensina I é clivada em angiotensina II pela enzima conversora de angiotensina $\mathrm{I}-\mathrm{ECA}^{66}$. A angiotensina II é um potente vasoconstritor, ela ativa a liberação de ADH, hormônio antidiurético, pela hipófise, e de aldosterona, pelo córtex da adrenal. Dessa forma, ocorre absorção e retenção de água pelos túbulos distais nos rins e simultaneamente 
reabsorção de sódio e cloreto. A angiotensina II também aumenta a atividade simpática e promove a vasoconstrição de arteríolas. Assim, com o aumento da volemia e a diminuição no calibre dos vasos sanguíneos a perfusão tecidual aumenta e a pressão arterial sistêmica se normaliza, inibindo os rins na liberação da renina.

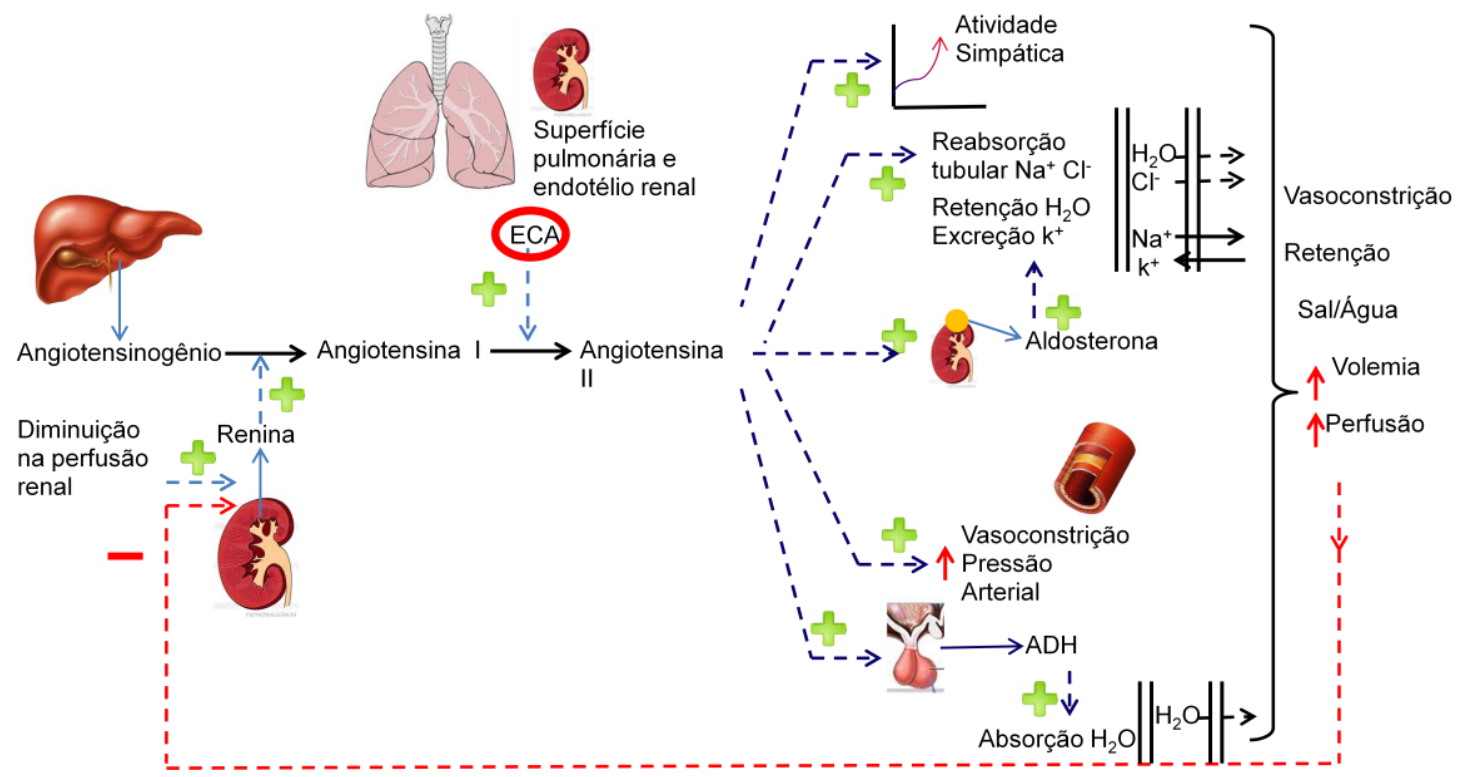

Figura 8 - Esquema de funcionamento da homeostase de pressão arterial sistêmica, realizado pelo Sistema Renina Angiotensina Aldosterona (SRAA). Adaptado de Aria Rad - $2006^{67}$.

\subsubsection{Enzima conversora de angiotensina I - ECA}

A enzima conversora de angiotensina (ECA), descrita em 1956, é uma dipeptidilcarboxilase que ativa um vasoconstritor potente quando converte angiotensina I (10 aminoácidos) em angiotensina II ( 8 aminoácidos $)^{65}$. Exerce ainda um efeito antivasodilatador ao inativar o sistema das cininas (bradicinina, substância P) ${ }^{65,68}$. A ECA que está presente em todo endotélio vascular sistêmico (60\%), sendo mais abundante no endotélio vascular pulmonar (40\%), e também é classificada como uma metalopeptidase zinco-dependente, cuja principal função é a conversão da angiotensina $\mathrm{I}$ em angiotensina $\mathrm{II}^{68}$. O gene responsável pela expressão da ECA está localizado no cromossomo 17, e o polimorfismo mais conhecido e estudado desse gene foi descrito há duas décadas e consiste na presença (alelo I) ou ausência (alelo D) de um fragmento Alu, de 287 pares de bases, próximo à extremidade 3' do intron 16. Essa variação polimórfica expressa três genótipos: II, ID e DD. O polimorfismo I/D da 
ECA está associado a 47\% da variabilidade fenotípica das concentrações da ECA sérica, sendo as concentrações mais elevadas associadas à presença do alelo $\mathrm{D}^{13}$. A concentração de ECA elevada que o alelo D origina, leva a um quadro de predisposição à hipertensão arterial sistêmica. No entanto, os mecanismos moleculares não são totalmente conhecidos. Um dos eventos responsáveis é a constrição continua dos vasos sistêmicos e teciduais, que, a longo prazo, também favorece com o quadro de hipertensão arterial sistêmica crônica.

Os polimorfismos genéticos do sistema renina angiotensina são correlacionados com doença renal em estado terminal ${ }^{69}$. Em estudo realizado durante 7 anos, a hipertensão arterial sistêmica e a hipertrofia ventricular esquerda foram analisadas em relação ao polimorfismo I/D do gene da ECA e confirmada a associação entre essas patologias e o polimorfismo em questão $^{70}$. Estudos in vivo indicam que o polimorfismo inserção/deleção da ECA também modula o metabolismo humano da bradicinina (potente vasodilatador) ${ }^{68}$. O polimorfismo I/D do gene ECA também está associado à sobrevida de pacientes com leucemia ${ }^{71}$. Além disso, um estudo recente realizado por CAM et. al associa o polimorfismo I/D do gene ECA e o polimorfismo eNOS G894T com disfunção erétil ${ }^{72}$. Alguns Kits para detectar polimorfismos associados com hipertensão já foram descritos. Por exemplo, Jiang L. e Pan J., desenvolveram um kit para a detecção de 4 polimorfismos diferentes relacionados com hipertensão arterial para a triagem de mulheres grávidas, em risco de desenvolver hipertensão arterial. O kit contém pares de primers específicos para a detecção de polimorfismos associados com hipertensão arterial, dentre eles o polimorfismo de deleção e inserção do gene da $\mathrm{ECA}^{73}$. Outro Kit descrito por Feng Z. e Zou Z. associam a detecção de 3 polimorfismos localizados no gene ECA, AGTR1 e NOS3 em um teste de PCR com sondas fluorescentes para detectar a suscetibilidade a hipertensão ${ }^{74}$.

\subsubsection{Diagnóstico para hipertensão arterial sistêmica}

O diagnóstico da hipertensão arterial sistêmica é clínico, estabelecido pela frequência de níveis tensionais permanentemente elevados acima dos limites considerados para a normalidade, quando a pressão arterial é determinada por meio de métodos e condições apropriados. Dessa maneira, a medida da pressão arterial é o elemento-chave para o

estabelecimento do diagnóstico de hipertensão arterial sistêmica ${ }^{75}$. Os métodos para a avaliação são: medida indireta, medida domiciliar, automedida e medida ambulatorial. $\mathrm{O}$ 
diagnóstico clínico laboratorial só é realizado e indicado para investigação da etiologia da hipertensão arterial, identificação dos fatores de risco para doenças cardiovasculares, e avaliação de lesões em órgãos-alvo. Além disso, o diagnóstico clínico laboratorial engloba a história clínica da patologia, exames físicos e exames laboratoriais como eletrocardiograma e colesterol total $^{75}$. No entanto, nenhuma triagem biomolecular genética é realizada antes do indivíduo apresentar índices fora dos padrões para normalidade permanentemente.

A necessidade de sistematização obriga uma definição operacional para separar indivíduos sadios dos doentes. Contudo, na realidade, podemos ter maior ou menor risco cardiovascular, tanto acima, como abaixo do número limítrofe, quando o paciente é considerado individualmente, já que a hipertensão arterial sistêmica não é um fator único e exclusivo para o desenvolvimento de doenças cardiovasculares. Além disso, os números são arbitrários e qualquer classificação é insuficiente. Assim, enfatiza-se a necessidade de extrema prudência antes de classificar um indivíduo como hipertenso, tanto pelo risco de falsopositivo como pela repercussão na própria saúde do indivíduo e o custo social resultante. Os limites normais para indivíduos adultos (com mais de 18 anos de idade) são inferiores a 85 mmHg de pressão diastólica, e inferiores a $130 \mathrm{mmHg}$ de pressão sistólica (Tabela 1). Indivíduos com valores tensionais $130-139 \mathrm{mmHg} / 85-89 \mathrm{mmHg}$ são classificados em normal limítrofe e ainda podem se beneficiar com as medidas preventivas ${ }^{75}$.

Tabela 1 - Classificação diagnóstica da hipertensão arterial (> 18 anos de idade).

\begin{tabular}{ccc}
\hline PAD mmHg & PAS mmHg & Classificação \\
$<85$ & $<130$ & Normal \\
$85-89$ & $130-139$ & Normal limítrofe \\
$90-99$ & $140-159$ & Hipertensão leve (estágio 1) \\
$100-109$ & $160-179$ & Hipertensão moderada (estagio 2) \\
$>$ ou igual 110 & $>$ ou igual 180 & Hipertensão grave (estágio 3) \\
$<90$ & $>$ ou igual 140 & Hipertensão sistólica isolada \\
\hline
\end{tabular}

O tratamento da hipertensão arterial pode ser medicamentoso ou não medicamentoso, com medidas preventivas. No entanto, mesmo a prevenção de hipertensão arterial envolve, fundamentalmente, ensinamentos para que se ocorram mudanças dos hábitos de vida, tanto no que se refere ao tratamento não medicamentoso, quanto ao tratamento com agentes antihipertensivos. A consecução dessas mudanças é lenta e, na maioria das vezes, inatingível, e por serem medidas educativas, necessitam de continuidade em sua implementação. $\mathrm{O}$ tratamento não medicamentoso tem como principal objetivo diminuir a morbidade e a 
mortalidade cardiovasculares, por meio de modificações do estilo de vida que favoreçam a redução da pressão arterial. Esse tratamento apresenta vantagens como o baixo custo e risco mínimo, além de aumentar a eficácia do tratamento medicamentoso. Ele é indicado a todos os hipertensos e aos indivíduos mesmo que normotensos, mas de alto risco para doenças cardiovasculares. Dentre essas modificações do estilo de vida, as que comprovadamente reduzem a pressão arterial são: redução do peso corporal, redução da ingestão do sal e do consumo de bebidas alcoólicas, prática de exercícios físicos com regularidade, e a não utilização de drogas que elevam a pressão $\operatorname{arterial}^{75}$. Essas modificações fazem parte de uma nova filosofia no tratamento, que sustenta a base da medicina preventiva, mas ainda muito distante do sucesso de implementação. A dificuldade de aplicar medidas preventivas na população é de nível cultural e universal. Assim, é necessária a busca por diagnósticos avançados, que sejam capazes de apresentar no mínimo a predisposição à determinadas patologias, para corroborar o processo de convencimento a adesão das medidas preventiva. 


\section{OBJETIVOS}

\subsection{Objetivo geral}

O presente trabalho teve como objetivo desenvolver sistemas para detecção do polimorfismo de inserção e deleção do gene da enzima conversora de angiotensina I, para serem empregados como diagnósticos avançados da predisposição à hipertensão arterial sistêmica, e, dessa forma, contribuir com a base preventiva da medicina. Alem disso, expandir o campo de genossensores nanoestruturados visando o entendimento e a caracterização das interações entre nanopartículas de ouro com oligonucleotídeos.

\subsection{Objetivos específicos}

- Sintetizar e caracterizar nanopartículas de ouro estabilizadas com dendrímero poli(amidoamina) de geração 4 (PAMAM G4);

- Complexar nanopartículas de ouro com oligonucleotídeo (pequena sequência de DNA) específico para a delecão de um fragmento Alu de 287 pb, no intron 16 do gene ECA, que leva à predisposição para hipertensão arterial sistêmica;

- Caracterizar o conjugado, AuNP-PAMAM G4/Oligonucleotídeo, e averiguar a interação do DNA com a nanopartícula;

- Investigar o processo de imobilização da região modificada do DNA, região 5' tiolada;

- Avaliar a reposta DNA/DNA alvo/AuNP-PAMAM G4-Oligonucleotídeo por meio de espectroscopia de impedância elétrica e eletroquímica, utilizando eletrodos interdigitados e eletrodos recobertos de ouro;

- Avaliar a reposta DNA/DNA alvo por meio de espectroscopia em transistor de efeito de campo de porta estendida e separada (SEGFET), utilizando eletrodos recobertos de ouro. 


\section{MATERIAIS E MÉTODOS}

\subsection{Materiais}

Todos os reagentes foram adquiridos comercialmente. Para a síntese das nanopartículas de ouro foram utilizados Ácido tetracloáurico $\mathrm{HAuCl}_{4}$, Ácido fórmico, adquiridos da Sigma-Aldrich, e Dendrimero poli(amidoamina) geração 4.0 (PAMAM G4) adquirido da Dendritech. As sequências utilizadas na construção dos genossensores e na conjugação com as nanopartículas de ouro estão descritas nas Tabelas 2, 3 e 4. Todas as sequências foram adquiridas liofilizadas da Invitrogen (Life Technologies) e eluídas em tampão TE $1 X$ (Tris-HCl e EDTA).

Tabela 2 - Sequências utilizadas na construção do genossensor com detecção elétrica.

\section{Sequência}

Sequência de captura $\quad$ 5'Tiol-GAGAGCCACTCCCATCCTTTCTC3'

Sequência não complementar

5'ACACCACACAACCCACCCACCCACA3'

Sequência alvo

5'TTCAGAGCTGGAATAAAATTGGCGAAACCACATAAAAGTGA CTGTATAGGCAGCAGGTCTAGAGAAATGGGAGAAAGGATGG GAGTGGCTCTCCAG3,

Conjugado AuNP-PAMAM

G4/Oligonucleotídeo

5’'Tiol-ACAGTCACTTTTATGTGGTTTCGCC3'

Tabela 3 - Sequências utilizadas na construção do genossensor com detecção eletroquímica.

\section{Sequência}

Sequência de captura

5'Tiol-GAGAGCCACTCCCATCCTTTCTC3'

5’TTCAGAGCTGGAATAAAATTGGCGAAACCACATAAAAGT

Sequência alvo

GACTGTATAGGCAGCAGGTCTAGAGAAATGGGAGAAAGG

ATGGGAGTGGCTCTCCAG3' 
Tabela 4 - Sequências utilizadas na construção do genossensor com detecção SEGFET.

\section{Sequência}

\begin{tabular}{lr}
\hline Sequência de captura & 5'Tiol-ACAGTCACTTTTATGTGGTTTCGCC3' \\
Sequência não complementar & 5'ACACCACACAACCCACCCACCCACA3' \\
Sequência alvo & 5'GGCGAAACCACATAAAAGTGACTGT3' \\
\hline
\end{tabular}

No preparo do tampão TE (1X), usado para a eluição das sequências de oligonucleotídeos e no processo de imobilização nas plataformas, foram utilizados Tris(hidroximetil)aminometano hidrocloreto $\left(0,01 \mathrm{~mol} \mathrm{~L}^{-1}\right)$ e Ácido etilenodiamino tetraacético $\left(0,1 \mathrm{mmol} \mathrm{L}^{-1}\right)$ adquiridos da Sigma-Aldrich. O tampão PBS (do inglês, Phosphate Buffer Saline) 0,1 mol L-1 $\mathrm{pH}$ 7,4, foi preparado utilizando Fosfato de potássio monobásico, Fosfato de sódio dibásico 99\% e Hidróxido de sódio $\mathrm{NaOH}$, adquiridos da Sigma-Aldrich.

Nos processos de imobilização e caracterização eletroquímica também foram utilizados 2-Mercaptoetanol (2-ME), uma solução de Hexacianoferrato III de potássio $\left(\mathrm{K}_{3}\left[\mathrm{Fe}(\mathrm{CN})_{6}\right]\right) 5 \mathrm{mmol} \mathrm{L}{ }^{-1}$ e Brometo de etídeo, adquiridos da Sigma-Aldrich. Além desses reagentes, Acetona, Etanol, Hidróxido de potássio e solução Sulfonítrica (Dicromato de potássio e Ácido sulfúrico) foram usados para a limpeza das plataformas (eletrodos e microeletrodos interdigitados) utilizadas e foram obtidos da Sigma-Aldrich e da J.T.Baker. Todas as soluções descritas e utilizadas nesse trabalho foram preparadas utilizando água ultrapura produzida pelo sistema Milli-Q com resistividade de 18,2 $\mathrm{M} \Omega \mathrm{cm}$.

\subsection{Estudo do conjugado AuNP-PAMAM/Oligonucleotídeo}

\subsubsection{Síntese das nanopartículas de ouro estabilizadas em PAMAM-G4}

As Nanopartículas de Ouro (AuNPs) foram fabricadas pelo método de precipitação, no qual um agente redutor é adicionado a uma solução de ácido cloroáurico na presença de um polieletrólito estabilizante ${ }^{76}$. Nessa síntese, foi escolhido o dendrímero poli(amidoamina) de geração 4 (PAMAM G4), ilustrado na Figura 9, com estabilizante, com o intuito de sintetizar 
nanopartículas de tamanhos reduzidos e mais estáveis em meio aquoso ${ }^{77}$. Além disso, íons metais reduzidos na presença de dendrímeros podem levar à formação de nanopartículas retidas na cavidade do dendrímero, permitindo um melhor controle da forma e da dispersão de tamanhos das nanopartículas ${ }^{26}$.

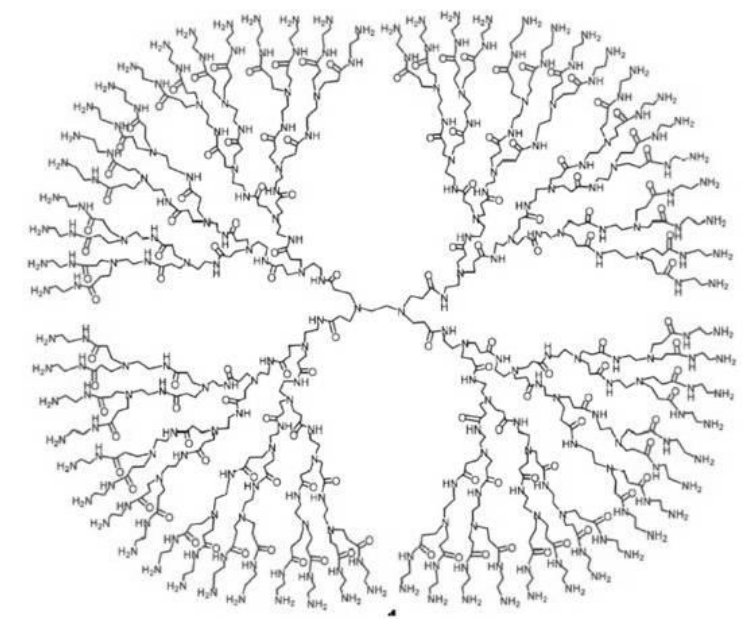

Figura 9 - Estrutura molecular do dendrímero poli(amidoamina) de geração 4 - PAMAM G4 ${ }^{78}$.

A metodologia para obtenção das nanopartículas de ouro estabilizadas com PAMAM G4 (AuNP-PAMAM G4) consistiu basicamente na adição sob agitação constante de soluções aquosa com volumes iguais de $\mathrm{HAuCl}_{4}$ (ácido tetracloáurico) de $1,0 \mathrm{mmol} \mathrm{L}{ }^{-1}$ e PAMAM G4 $0,07 \mathrm{mmol} \mathrm{L}^{-1} \mathrm{e}$, em seguida, uma solução de ácido fórmico $10 \%(\mathrm{v} / \mathrm{v})^{76}$. O sistema permaneceu aproximadamente 2,5 horas em agitação lenta e constante protegido da luz. Após a total redução do ouro e formação da suspensão de nanopartículas, a solução inicial de cor amarela clara tornou-se vermelha acastanhada como é mostrado na Figura 10. 


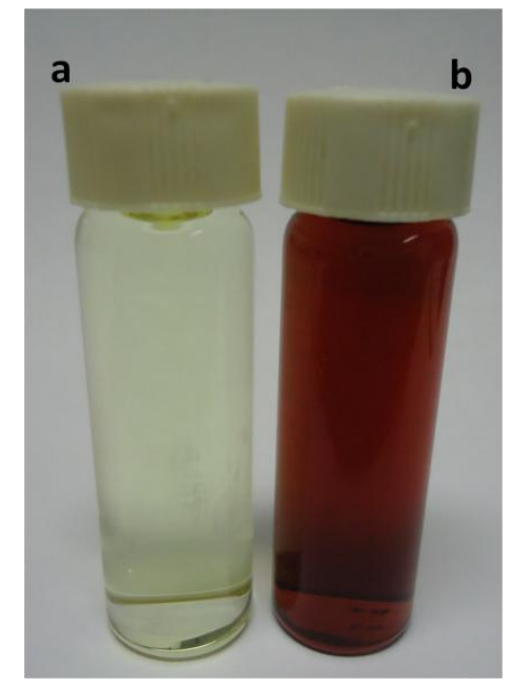

Figura 10 - Imagem das soluções na etapa inicial e final da síntese das nanopartículas de ouro, a) o sistema ainda na coloração amarela clara, permaneceu em agitação vigorosa constante em um agitador magnético e b) após 2,5 horas de agitação constante e protegido da luz a suspensão das nanopartículas de ouro está concluída, e apresenta uma coloração vermelha acastanhada, indicando a redução do ouro.

\subsubsection{Conjugação do oligonucleotídeo com as AuNP-PAMAM G4}

A sequência de oligonucleotídeo, 5'Tiol-ACAGTCACTTTTATGTGGTTTCGCC3', utilizada e adquirida para a conjugação com as nanopartículas de ouro foi desenhada e estudada, de acordo com o mapa gênico (disponível no anexo A), especificamente para o polimorfismo de inserção e deleção (I/D), localizado no cromossomo 17, na extremidade do Intron 16 do gene da enzima conversora de angiotensina I - ECA. Como já exposto anteriormente, esse polimorfismo está intimamente relacionado com a predisposição à hipertensão $\operatorname{arterial}^{13,68-69}$.

Sabendo da forte interação entre o ouro e o enxofre, os primeiros oligonucleotídeos adquiridos comercialmente tinham um grupo fosforotioato (Figura 11). Esse tipo de modificação $^{1}$ nos oligonucleotídeos troca um oxigênio do grupo fosfato por um enxofre (-S) e, dessa forma, a funcionalização ocorreria de forma mais estável por ligação covalente. No entanto, essa modificação do grupo fosforotioato estava presente em todos os nucleotídeos da sequência. Assim, a interação com as nanopartículas poderia ocorrer em forma de core/shell, recobrindo e contornando toda a nanopartícula, podendo inutilizar o conjugado na fase de hibridização, porque dessa maneira a molécula poderia diminuir a flexibilidade das bases nitrogenadas no momento da ligação com as bases complementares. 
Outra possível modificação nos oligonucleotídeos é a adição de um grupo tiol (-SH) ${ }^{79}$ na extremidade 5' da sequência do oligonucleotídeo, da mesma forma como na modificação com o grupo fosforotioato, ocorre também uma forte interação entre o ouro e o enxofre do oligonucleotídeo $^{23}$. No entanto, essa modificação com o grupo tiol é realizada apenas no grupo fosfato inicial da sequência, mais precisamente, na extremidade 5'. Dessa maneira, a conjugação entre as nanopartículas é mais uniforme e não prejudica a aplicação do conjugado na fase de hibridização, visto que, as de bases nitrogenadas ficam mais livres e, com isso, mais flexíveis para se ligarem em suas sequências complementares. Dessa maneira, o oligonucleotídeo utilizado foi adquirido com a adição de um grupo tiol linker $\mathrm{C}_{6}$ de fórmula $\mathrm{OH}-\mathrm{C}_{6}-\mathrm{S}-\mathrm{S}-\mathrm{C}_{6}-\mathrm{PO}_{3}$ na extremidade 5'.

A metodologia para a conjugação do oligonucleotídeo com as nanopartículas de ouro, AuNP-PAMAM/Oligonucleotídeo, consistiu primeiro na separação de uma alíquota de nanopartículas lavadas por meio de centrifugações sucessivas. Essas lavagens foram realizadas para aumentar o $\mathrm{pH}$ e deixá-lo mais próximo do $\mathrm{pH}$ fisiológico, visto que, as nanopartículas de ouro reduzidas com ácido fórmico apresentam $\mathrm{pH}$ muito baixo, aproximadamente 4,0, o que poderia ser desfavorável para as moléculas de DNA. Dessa maneira, 1,5 mL das AuNP-PAMAM G4, foram centrifugadas a $13.000 \mathrm{rpm}$ por 5 minutos, e posteriormente, o precipitado ressuspendendido com $1 \mathrm{~mL}$ de água ultra pura e centrifugado novamente. Esse ciclo de lavagem foi repetido por mais duas vezes. Um $\mathrm{mL}$ de AuNPPAMAM G4 lavadas foram adicionadas a $40 \mu \mathrm{L}$ de uma solução contendo 151,5 pmol $\mu \mathrm{L}^{-1}$ de oligonucleotídeo tiolado em tampão TE $1 \mathrm{X}$. O sistema permaneceu por 12 horas sob agitação lenta e constante a $4{ }^{\circ} \mathrm{C}$ protegido da luz. Posteriormente, o excesso de oligonucleotídeo que não estava eficientemente complexado foi removido por centrifugação. O sistema foi centrifugado a $13.000 \mathrm{rpm}$ por 15 minutos, o sobrenadante foi descartado e o precipitado ressuspendido em água Milli-Q. Esse processo de lavagem foi repetido mais duas vezes para eliminar ao máximo do excesso de oligonucleotídeo. A separação por Cromatografia de Exclusão Molecular também foi realizada, porém sem resultados satisfatórios (não apresentados), visto que, o conjugado AuNP-PAMAM/Oligonucleotídeo interagia fortemente com a coluna de exclusão molecular e permanecia até a eluição da coluna com hipoclorito de sódio. Dessa forma, não é possível utilizar, pois degrada o conjugado e anula a funcionalidade do mesmo. 

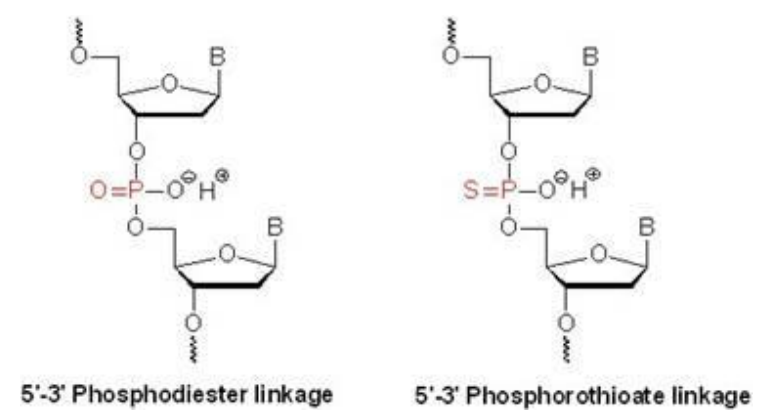

Figura 11 - Estrutura química de um fosfodiester e um fosforotioato. A alteração entre eles é a troca de um oxigênio (-O) do grupo fosfato por um enxofre $(-\mathrm{S})^{80}$.

\subsection{Construção do genossensor em modelo sanduíche}

O genossensor utilizado nas análises de espectroscopia de impedância elétrica e eletroquímica foi baseado na técnica de hibridização em modelo sanduíche. As sequências específicas para o polimorfismo estudado foram desenhadas utilizando o mapa gênico ${ }^{81}$ do gene da ECA.

A arquitetura para detecção do polimorfismo utilizada nesse trabalho consiste em imobilizar a sequência de oligonucleotídeo, chamada de sequência de captura, sobre eletrodos condutores. Esta sequência deve ser próxima da região que se quer analisar. Em seguida colocar o eletrodo em contato com a amostra a ser analisada, sequência alvo, e aquecer até a temperatura de annealing da sequência, para imobilizá-la ao eletrodo (por meio da hibridização com a sequência de captura). Após a lavagem, as sequências ancoradas fracamente são removidas. Uma parte do material a ser detectado hibridiza com a sequência de captura. A sequência de captura é desenhada para reagir com apenas parte da sequência alvo, de maneira que uma parte desta última ainda permaneça como fita simples após o ancoragem com a sequência de captura. Após hibridizar com apenas uma parte da sequência desejada, o sistema é colocado com uma terceira sequência conjugada com nanopartículas de ouro (AuNP-PAMAM/Oligonucleotídeo) complementar à parte da sequência alvo que não hibridizou. Essa sequência é composta por uma sequência de DNA conjugada com a nanopartícula de ouro e complementar ao polimorfismo da sequência alvo. Dessa forma, ocorrerá a hibridização do conjugado com oligonucleotídeo e nanopartículas, apenas se houver complementaridade na amostra analisada. A variação da resistividade do sistema é 
monitorada por meio de espectroscopia de impedância elétrica e espectroscopia de impedância eletroquímica, uma vez que, com as nanopartículas de ouro o sistema é menos resistivo. Uma ilustração da arquitetura desse dispositivo é representada na Figura 4.

\subsubsection{Imobilização do DNA na plataforma do genossensor elétrico}

As medidas de detecção elétrica foram realizadas utilizando-se eletrodos interdigitados, com trilhas de $\mathrm{Cr} / \mathrm{Au}$ depositadas sobre vidro. Uma ilustração esquemática dos eletrodos é mostrada na Figura 12. O eletrodo contém 24 pares de trilhas com distância de 40 $\mu \mathrm{m}$ entre elas. A metodologia para construção do genossensor consistiu primeiramente na imobilização da sequência de captura modificada com um grupo tiol, 5'TiolGAGAGCCACTCCCATCCTTTCTC3', nos microeletrodos interdigitados. Os microeletrodos foram imersos em uma solução contendo $3,16 \mu \mathrm{mol} \mathrm{L}^{-1}$ de oligonucleotídeo de captura, em tampão TE $1 \mathrm{X}$ por 12 horas. Após esse período os microeletrodos foram enxaguados em água ultrapura para a remoção dos oligonucleotídeos que não ancoraram fortemente nas trilhas de ouro. A secagem foi realizada sob fluxo brando de $\mathrm{N}_{2}$.

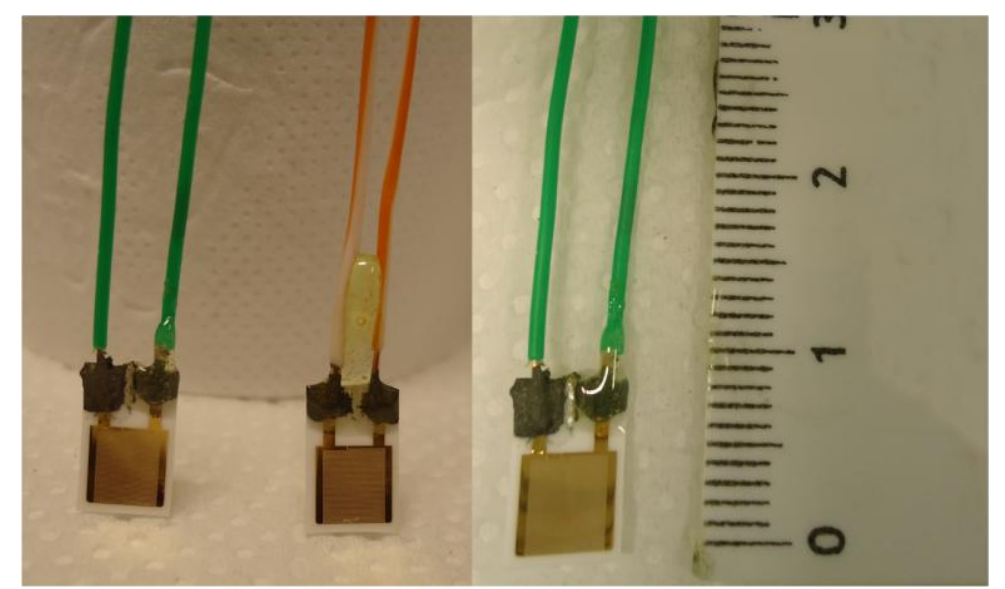

Figura 12 - Imagem dos microeletrodos interdigitados recobertos com ouro utilizados como plataforma do genossensor elétrico. 


\subsubsection{Imobilização do DNA na plataforma do genossensor eletroquímico}

Em plataformas de genossensoriamento eletroquímico, o sucesso da detecção do DNA alvo depende de fatores como o grau de organização das moléculas, e a modificação apropriada da superfície ${ }^{79,82}$. Um alto grau de organização das moléculas de DNA imobilizadas pode ser adquirido utilizando a técnica de monocamada auto-organizada mista $\left(\mathrm{SAM}_{\mathrm{mix}} \text {, do inglês Self-Assembled Mix Monolayer }\right)^{83}$. A $\mathrm{SAM}_{\text {mix }}$ promove uma autoorganização entre as moléculas de DNA e as outras moléculas da mistura na superfície. Dessa forma, facilitando a formação de ilhas de moléculas e possibilitando que as sequências de DNA sejam adsorvidas especificamente, e com uma tendência a mesma orientação, resultando em uma interface com moléculas bem orientadas e regiões de alta concentração de moléculas (Figura 13) ${ }^{79,83}$.
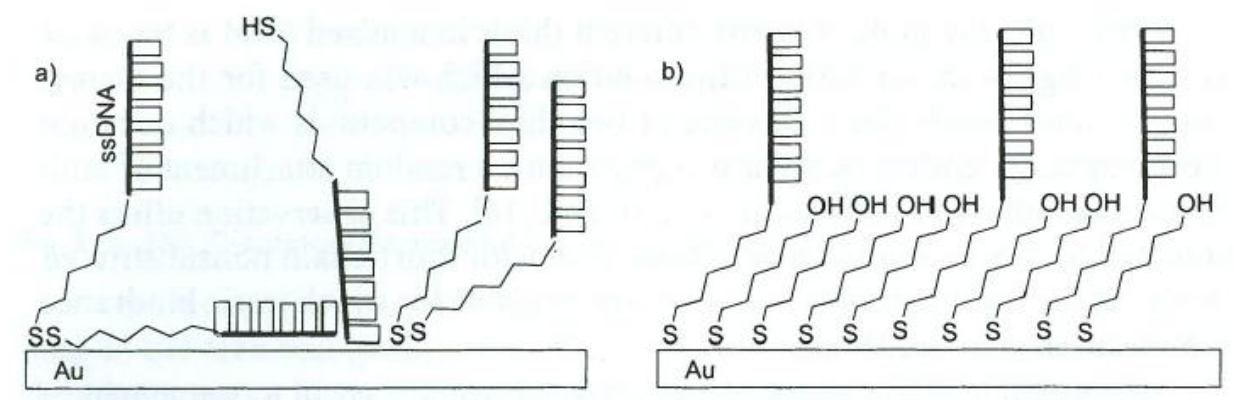

Figura 13 - Esquema de plataformas com a molécula imobilizada pura e com $\mathrm{SAM}_{\text {mix }}$ : (a) apenas sequências de DNA modificadas com tiol imobilizadas em superfície de ouro e (b) $\mathrm{SAM}_{\text {mix }}$ de sequências de DNA modificadas com tiol e 6-hidroxi-1-hexanotiol imobilizadas em superfície de ouro. ${ }^{79}$.

A metodologia para construção do genossensor utilizado na detecção eletroquímica foi baseada em $\mathrm{SAM}_{\text {mix }}$. A $\mathrm{SAM}_{\text {mix }}$ de tiol e oligonucleotídeo foi obtida por imersão dos eletrodos de ouro em uma solução contendo $0,12 \mathrm{mmol} \mathrm{L}^{-1}$ de 2-mercapto1-etanol e $2 \mu \mathrm{mol} \mathrm{L}$ 1 de sequência de captura, 5' Tiol -GAGAGCCACTCCCATCCTTTCTC3', em tampão TE 1X. O sistema permaneceu por 12 horas a $22^{\circ} \mathrm{C}$. Em seguida, os eletrodos foram enxaguados em água ultrapura, para remover as moléculas adsorvidas fracamente, e o excesso. A secagem foi realizada sob fluxo brando de $\mathrm{N}_{2}$. 


\subsection{Construção do genossensor para caracterização em Transistor de Efeito de Campo de Porta Estendida e Separada (SEGFET)}

\subsubsection{Imobilização do DNA na plataforma do genossensor para caracterização em SEGFET}

Existe a possibilidade de detectar de forma direta o processo de hibridização de sequências DNA (sem necessidade de uma terceira fita contendo nanopartículas ou marcadores utilizando dispositivos de efeito de campo (FEDs, do inglês Field-Effect Devices) ${ }^{51}$. Portanto, testamos também uma variação do ISFET (Figura 7) associado ao modelo de hibridização direta. Além disso, foram testadas duas formas de imobilização visando uma boa orientação e organização molecular, além de uma maior especificidade. Uma das metodologias para construção do genossensor utilizado na detecção SEGFET foi baseada em $\mathrm{SAM}_{\text {mix }}$. A $\mathrm{SAM}_{\text {mix }}$ de tiol e oligonucleotídeo foi obtida por imersão dos eletrodos de ouro em uma solução contendo $0,12 \mathrm{mmol} \mathrm{L}^{-1}$ de 2 -mercapto1-etanol e $2 \mu \mathrm{mol} \mathrm{L}$ ${ }^{1}$ de sequência de captura, 5'Tiol-ACAGTCACTTTTATGTGGTTTCGCC3'em tampão TE 1X. O sistema permaneceu por 12 horas a $22{ }^{\circ} \mathrm{C}$. Em seguida, os eletrodos foram enxaguados em água ultrapura, para remover as moléculas adsorvidas ineficientemente, e o excesso. A secagem foi realizada sob fluxo brando de $\mathrm{N}_{2}$. Outra imobilização estudada foi a imobilização direta sem a $\mathrm{SAM}_{\text {mix }}$, na qual consistiu na imobilização apenas da sequência de captura modificada com um grupo tiol, 5'Tiol-ACAGTCACTTTTATGTGGTTTCGCC3' nos eletrodos de ouro. Os eletrodos foram imersos em uma solução contendo $2 \mu$ mol L ${ }^{-1}$ de oligonucleotídeo de captura, em tampão TE $1 \mathrm{X}$. O sistema também permaneceu por 12 horas a $22{ }^{\circ} \mathrm{C}$. Em seguida, os eletrodos foram enxaguados em água ultrapura, para remover as moléculas adsorvidas ineficientemente, e o excesso. A secagem foi realizada sob fluxo brando de $\mathrm{N}_{2}$. 


\subsection{Técnicas de caracterização}

\subsubsection{Espectroscopia no Ultravioleta-Visível (UV-VIS)}

As técnicas espectroscópicas de absorção são muito utilizadas. Em particular, as espectroscopias no UV-VIS podem ser usadas com vários objetivos, desde a determinação de concentrações até a resolução de questões estruturais complexas.

Espectroscopia no UV-VIS é uma técnica amplamente utilizada para análises de moléculas biológicas. No DNA os principais elementos que apresentam transições eletrônicas na região do ultravioleta são os anéis das purinas e pirimidinas presentes nas bases nitrogenadas (adenina, guanina, timina e citosina) com fortes absorções entre 240 e $275 \mathrm{~nm}^{84}$. Nessa técnica, a quantificação de moléculas biológicas pode ser determinada por meio da absorção que é diretamente proporcional a concentração, de acordo com a lei de BeerLambert $^{85}$ (Equação 1).

$$
A=\varepsilon . c . \ell
$$

Onde $A$ é a absorbância, $\varepsilon$ é o coeficiente de absortividade molar, $c$ é a concentração e $\ell$ o caminho óptico. Além das moléculas biológicas, também é possível estimar a concentração de nanopartículas metálicas esféricas por meio da teoria de $\mathrm{Mie}^{86}$, que, de forma geral, correlaciona a radiação absorvida pela nanopartícula com a radiação espalhada, sendo a absorbância total relacionada com a secção transversal das nanopartículas, é possível calcular a radiação total em função do tamanho das nanopartículas analisadas.

A espectroscopia de absorção no ultravioleta visível foi empregada no estudo das nanopartículas de ouro AuNP-PAMAM G4 e dos conjugados AuNP-PAMAM G4/Oligonucleotídeo com o propósito de quantificar e avaliar a existência da conjugação das nanopartículas aos oligonucleotídeos, visto que, a interação entre moléculas podem provocar alterações no espectro de absorção ou alargamento de picos ${ }^{87}$. Foi utilizado o espectrômetro de modelo U-2900 da empresa Hitachi, pertencente ao Grupo de Biofísica - IFSC/USP. As cubetas para as medidas eram de quartzo com volumes de $0,5 \mathrm{~mL}$ e o caminho óptico de 1 cm. Foram analisadas a solução de AuNP-PAMAM G4, diluída da síntese inicial em 10 vezes, uma solução do oligonucleotídeo livre eluído em tampão TE $1 \mathrm{X}$, a solução do 
conjugado AuNP-PAMAM G4/Oligonucleotídeo, o precipitado da solução do conjugado após centrifugação, e o sobrenadante da solução.

\subsubsection{Espalhamento Dinâmico de Luz (DLS)}

O Espalhamento Dinâmico de Luz (DLS, do inglês Dynamic Light Scattering) é uma técnica amplamente utilizada no estudo de partículas em solução e suspensão, como proteínas, polímeros, micelas, carboidratos, nanopartículas, dispersões coloidais, emulsões, microemulsões, vesículas lipídicas e várias outras moléculas, sendo a maioria de interesse biológico $^{88}$. O DLS é uma técnica não-invasiva, de fácil utilização com medidas rápidas e precisas para distribuições monodispersas e com distribuição de tamanhos pequenos. Além disso, pode-se medir ao mesmo tempo a carga superficial das partículas. Baseado no espalhamento de luz mediante o tamanho das partículas, as detecções medem as flutuações da intensidade do espalhamento em função do tempo ${ }^{87}$.

As partículas dispersas em um meio líquido movem-se pelo movimento Browniano. Partículas menores movem-se mais rapidamente que partículas grandes, assim possuem coeficiente de difusão $(D)$ maior. Para uma dispersão de partículas esféricas, com viscosidade $\eta$, sob temperatura constante $T$, a $k$ que é a constante de Boltzmann, o coeficiente de difusão $D$ é inversamente proporcional ao diâmetro hidrodinâmico $d_{h}$ das partículas, essa relação está apresentada na Equação 2 de Stokes- Einstein ${ }^{87}$ :

$$
D=\frac{K \cdot T}{3 \pi \eta d_{h}}
$$

O espalhamento dinâmico de luz foi utilizado na caracterização das distribuições de tamanhos da AuNP-PAMAM G4, do oligonucleotídeo, e do AuNP-PAMAM G4/Oligonucleotídeo. O equipamento utilizado nas análises de DLS foi um Zetatrac (Microtrac Inc.) pertencente ao Grupo de Polímeros - IFSC/USP, algumas medidas também foram realizadas em um equipamento Malvern Spectrometer Nano-ZS (Malvern Instruments UK) pertencente a Embrapa, São Carlos. As medidas foram realizadas em triplicatas, em temperatura ambiente. As amostras AuNP-PAMAM G4 e AuNP-PAMAM 
G4/Oligonucleotídeo foram dispersas em água ultrapura, e o oligonucleotídeo livre em tampão TE $1 \mathrm{X}$.

\subsubsection{Potencial Zeta (ל)}

O termo potencial Zeta (ל), segundo a teoria de DVLO (inicial dos nomes dos pesquisadores Derjaguin, Verwey, Landau e Overbeek) ${ }^{89}$, envolve a somatória do potencial relacionado ao solvente, do potencial atrativo e do potencial repulsivo do material. A técnica que avalia o potencial Zeta $(\zeta)$ é baseada também no espalhamento dinâmico de luz. No entanto, neste caso a cubeta na qual se encontra a suspensão a ser analisada contém dois eletrodos, nos quais uma diferença de potencial (ddp) é aplicada, gerando a movimentação das partículas em suspensão. Quando as partículas se movimentam os íons contidos em sua camada de Stern e em sua camada mais difusa movimentam-se com ela, assim, o espalhamento de luz é gerado. De maneira geral, a velocidade das partículas é determinada em função da diferença de potencial, e sabendo a viscosidade e a constante dielétrica da amostra é possível calcular o valor do potencial Zeta da suspensão ${ }^{90}$.

As partículas em suspensão apresentam uma carga eletrostática superficial, e com a quantificação das cargas eletrostáticas da superfície, é possível saber se uma partícula é estável em determinado meio ou não. A estabilidade de uma suspensão depende de seu potencial total, e quanto maior esse potencial em módulo, mais estável as partículas estarão no meio $^{90}$. O potencial $\zeta$ foi utilizado na caracterização da AuNP-PAMAM G4, do oligonucleotídeo, e do AuNP-PAMAM G4/Oligonucleotídeo, com o intuito de conhecer a estabilidade desses compostos e confirmar a formação do conjugado.

O equipamento utilizado nas análises do potencial Zeta é o mesmo do DLS, Zetatrac (Microtrac Inc.) pertencente ao Grupo de Polímeros - IFSC/USP, algumas medidas também foram realizadas em um equipamento Malvern Spectrometer Nano-ZS (Malvern Instruments UK) pertencente a Embrapa São Carlos. O potencial $\zeta$ das suspensões foi analisado a $25^{\circ} \mathrm{C}$ em triplicata para cada amostra. As amostras AuNP-PAMAM G4 e AuNP-PAMAM G4/Oligonucleotídeo foram dispersas em água ultra pura e o oligonucleotídeo livre em tampão TE $1 X$. 


\subsubsection{Microscopia Eletrônica de Transmissão (TEM)}

A microscopia eletrônica de transmissão (TEM, do inglês Transmission Electron Microscopy) é uma técnica de alta resolução que permite a visualização de estrutura muito pequenas, da ordem de nanômetros. Sucintamente, a técnica é baseada na aceleração de um feixe de elétrons emitido em direção a uma amostra ultrafina, esses elétrons interagem com a amostra enquanto a cruzam formando a imagem. A TEM é capaz de promover imagens a uma resolução excepcional e muito maior em comparação aos microscópios ópticos, e isso se deve ao pequeno comprimento da onda dos elétrons. Desta forma, a técnica é empregada em vários estudos morfológicos na área de virologia, no câncer e na ciência de materiais, se destacando na caracterização de nanomateriais e nanocompósitos. Além disso, recentemente, a técnica vem sendo utilizada para resolver a estrutura tridimensional de proteínas.

TEM foi empregada para visualizar, quando possível, a conjugação das nanopartículas com o DNA. As imagens foram obtidas em um microscópio eletrônico JEOL JEM-2100 operando a $200 \mathrm{kV}$, pertencente ao Laboratório de Microscopia Eletrônica no Laboratório Nacional de Luz Síncrotron em Campinas, e foram realizadas em colaboração, pela aluna Valéria Spolon estudante de doutorado do nosso grupo, a qual apresenta o treinamento específico e indispensável para manusear esse microscópio. O sistema foi preparado depositando uma gota da suspensão aquosa da nanopartícula sobre uma grade de cobre recoberta por um filme fino de carbono 300 mesh (Ted Pella, Inc.) Após a deposição da gota sobre o suporte, a água foi lentamente evaporada a temperatura ambiente. As análises estatísticas do diâmetro médio e desvio padrão das nanopartículas foram realizadas pela contagem de 100 a 250 partículas usando o software de domínio publico ImageJ desenvolvido pelo National Institute of Health, NIH, Estados Unidos.

\subsubsection{Reação em Cadeia da Polimerase em Tempo Real}

A reação em cadeia da polimerase em tempo real (PCR Real-Time, do inglês RealTime Polymerase Chain Reaction) é utilizada para amplificar material genético. Como o nome indica, é possível acompanhar essa reação no momento em que ela está ocorrendo, em tempo real. A técnica utiliza um fator fluorescente, que se intercala nas bases nitrogenadas do 
DNA em fita dupla. Assim, conforme as novas fitas vão se formando, o fator vai se intercalando, aumentando dessa forma a fluorescência detectada. Essa técnica foi utilizada para analisar a funcionalidade do oligonucleotídeo após a conjugação com as nanopartículas e validar as etapas de detecções, hibridização com a sequência complementar, no genossensor. Os testes foram realizados em um termociclador modelo CFX96 BIO-RAD pertencente ao Laboratório de Genética e Evolução durante um treinamento de Real-Time PCR, ministrado pela BIO-RAD na Universidade Federal de São Carlos - UFSCar. Nas reações testadas foram utilizadas a sequência que seria amplificada, denominada de "DNA molde", 5'TTCAGAGCTGGAATAAAATTGGCGAAACCACATAAAAGTGACTGTATAGGCA CAGGTCTAGAGAAATGGGAGAAAGGATGGGAGTGGCTCTCCAG3', com o primer controle, sem nanopartícula, 5'Tiol-ACAGTCACTTTTATGTGGTTTCGCC3', ou com o primer testado complexado com a nanopartícula, AuNP-PAMAM G4/Oligonucleotídeo, 5'•Au-Tiol-ACAGTCACTTTTATGTGGTTTCGCC3', descritos na Tabela 5. As amplificações foram realizadas em uma placa específica do equipamento com o kit SYBR Green supermix da BIO-RAD em um volume de $20 \mu \mathrm{L}$, todas as reações foram testadas em duplicata. Os 39 ciclos aplicados depois da desnaturação $\left(98^{\circ} \mathrm{C}\right.$ por 2 minutos) respeitaram 98 ${ }^{\circ} \mathrm{C}$ por 10 segundos $\rightarrow$ annealing $68{ }^{\circ} \mathrm{C}$ por 30 segundos $\rightarrow$ e ciclo de extensão. As amplificações foram analisadas pelo software CFX Manager ${ }^{\mathrm{TM}}$ da BIO-RAD.

Tabela 5 - Descrição dos reagentes utilizados na Real-Time PCR.

\begin{tabular}{|c|c|c|c|c|}
\hline $\begin{array}{l}\text { Localização } \\
\text { Placa }\end{array}$ & $\begin{array}{r}\text { [DNA molde] } \\
\mu \mathrm{mol} \mathrm{L}-1\end{array}$ & $\begin{array}{l}\text { [Primer controle] } \\
\mu \mathrm{mol} \mathrm{L}{ }^{-1}\end{array}$ & $\begin{array}{l}\text { KitSYBR } \\
\text { volume } \mu \mathrm{L}\end{array}$ & $\begin{array}{l}\text { ÁguaMilli-Q } \\
\text { volume } \mu \mathrm{L}\end{array}$ \\
\hline A1 & 0,15 & 0,30 & 10 & 7,0 \\
\hline A2 & 0,15 & $\mathbf{0 , 3 0}$ & 10 & 7,0 \\
\hline B1 & $\mathbf{0 , 3 0}$ & $\mathbf{0 , 3 0}$ & 10 & 6,0 \\
\hline B2 & $\mathbf{0 , 3 0}$ & 0,30 & 10 & 6,0 \\
\hline Localização & [DNA molde] & [Primer conjugado] & KitSYBR & ÁguaMilli-Q \\
\hline Placa & $\mu \mathrm{mol} \mathrm{L}-1$ & $\begin{array}{l}\text { AuNP-PAMAM G4/Oligonucleotídec } \\
\mu \mathrm{mol} \mathrm{L}{ }^{-1}\end{array}$ & volume $\mu \mathrm{L}$ & volume $\mu \mathrm{L}$ \\
\hline $\mathrm{C1}$ & 0,15 & $\mathbf{0 , 3 0}$ & 10 & 7,0 \\
\hline $\mathrm{C} 2$ & 0,15 & 0,30 & 10 & 7,0 \\
\hline D1 & $\mathbf{0 , 3 0}$ & 0,60 & 10 & 7,0 \\
\hline D2 & $\mathbf{0 , 3 0}$ & $\mathbf{0 , 6 0}$ & 10 & 7,0 \\
\hline
\end{tabular}




\subsubsection{Espectroscopia no Infravermelho (FTIR)}

A técnica de espectroscopia no infravermelho com transformada de Fourier (FTIR, do inglês Fourier Transform Infrared Spectroscopy) é uma técnica de absorção na região do infravermelho do espectro eletromagnético. Praticamente qualquer composto com ligações covalentes absorve várias frequências de radiação eletromagnética na região do infravermelho (IV), com variações de energia da ordem de $8-40 \mathrm{~kJ} / \mathrm{mol}$ correspondentes aos alongamentos e distorções angulares da molécula ${ }^{91}$.

A espectroscopia no Infravermelho tem sido utilizada no estudo das interações de nanomateriais conjugados a DNA ${ }^{92-95}$. Portanto, o objetivo de usar a FTIR na caracterização dos conjugados foi justamente o de analisar por quais grupos as nanopartículas, AuNPPAMAM G4, estavam ligadas com o oligonucleotídeo, e confirmar a formação do conjugado AuNP-PAMAM G4/Oligonucleotídeo. Para isso, as amostras foram depositadas em casting sobre lâminas de silício previamente limpas, visto que, o Si é transparente no Infravermelho permitindo a sua utilização em análises de FTIR. Posteriormente, as lâminas foram secadas em um dessecador à vácuo com sílica gel, até que a água fosse evaporada e a umidade eliminada. Após secagem, as lâminas foram imediatamente analisadas. $\mathrm{O}$ equipamento utilizado para essas medidas foi um espectrofotômetro Thermo Nicolet 6700 FT-IR (TQ Analyst) o qual pertence ao Grupo de Cristalografia - IFSC/USP. Os espectros foram obtidos por meio de 200 medidas com resolução de $4 \mathrm{~cm}^{-1}$, em modo de transmitância, no intervalo de 400 a $4000 \mathrm{~cm}^{-1}$.

\subsubsection{Microscopia Confocal de Fluorescência}

A microscopia confocal de fluorescência utiliza compostos químicos denominados fluoróforos que são excitados por uma fonte de LASER, e, por meio de um conjuntos de lentes o sistema é capaz de focar um cone de luz LASER em uma profundidade predeterminada da amostra. A profundidade pode ser mantida enquanto se muda o ponto focal e, dessa forma, é possível visualizar o plano amostral por inteiro e ponto a ponto. Além disso, essa técnica tem um sistema capaz de filtrar as luzes emitidas pela amostra toda e captar apenas a luz do ponto focado, eliminado a emissão de luz dos pontos que estão fora do foco, e 
dessa forma é possível construir imagens bidimensionais com vários fluoróforos diferentes e com resoluções extremamente precisas. A microscopia confocal, além de ter proporcionado um notável avanço em estudos de organismos vivos, é fundamental para análises de células, eventos biológicos e interações físico-químicas e, dessa maneira, permite ampliar os conhecimentos em várias áreas da biologia. Essa técnica é muito empregada em estudos de nanotoxicidade, por meio da análise em tempo real da interação dos nanomateriais com sistemas biológicos ${ }^{96-99}$. A microscopia confocal foi empregada neste trabalho para investigar a presença de DNA no genossensor e a organização das moléculas sobre o eletrodo de ouro. Foi utilizado um microscópio confocal de fluorescência modelo LSM 780 (ZEISS) pertencente ao IFSC/USP. Todas as imagens foram realizadas com a supervisão de indivíduos treinados para o manuseio do equipamento, devido à quantidade e complexidade de recursos que o equipamento oferece. Foram analisados os eletrodos nas três etapas separadas de construção do genossensor (Figura 28). O fluoróforo utilizado foi o Brometo de etídeo $\left(\mathrm{C}_{21} \mathrm{H}_{20} \mathrm{BrN}_{3}\right)$ o qual se intercala nas bases nitrogenadas do DNA, e é excitado no comprimento de onda $535 \mathrm{~nm}$ (azul-verde) com emissão no comprimento de onda de $602 \mathrm{~nm}$ (vermelho $)^{100}$. Após cada etapa de construção do genossensor para detecção eletroquímica, os eletrodos foram incubados por 10 minutos em uma solução contendo $0,1 \mu \mathrm{g} \mathrm{mL}^{-1}$ de Brometo de etídeo e, posteriormente, os eletrodos foram lavados várias vezes em água ultrapura para retirar o excesso de marcador não intercalado. Foi realizada a varredura por todo o eletrodo e o experimento foi repetido em duplicata.

\section{5. 8 Espectroscopia de Impedância}

\subsubsection{Espectroscopia de Impedância Elétrica}

A espectroscopia de impedância elétrica é baseada na análise da impedância em função da frequência de um sinal aplicado em potenciais alternados (AC). Essa técnica permite a análise dos processos de condução elétrica em materiais sólidos e líquidos que apresentem algum grau de resistividade elétrica. Em uma medida de espectroscopia de impedância promove-se uma varredura de frequência, partindo de uma frequência inicial da 
ordem de $0,1 \mathrm{~Hz}$ até frequências da ordem de $10^{7} \mathrm{~Hz}$. O espectro de impedância apresenta os principais processos de transporte eletrônicos, iônicos, injeção de portadores de carga e diferenças nas fases estruturais do material. Por meio da impedância complexa pode-se obter seu recíproco, a admitância complexa, além da resistividade elétrica e a condutividade. Uma forma de representação da impedância é mostrada na Figura 14b, na qual a impedância complexa é apresentada na forma de um diagrama de Nyquist. O diagrama de Nyquist, normalmente, inclui uma região de semicírculo seguido de uma linha reta (curva a), a região do semicírculo, observada em frequências mais altas, corresponde ao processo de transferência eletrônica, já a região linear do espectro é característica de frequências mais baixas e abrange o processo eletroquímico limitado pela difusão. Quando o processo de transferência de elétrons é muito rápido, o espectro de impedância pode apresentar apenas a região linear (curva b), enquanto no processo de transferências muito lento o resultado é uma grande região de semicírculo que não é acompanhada pela região linear (curva c). Assim, a cinética de transferência de elétrons e as características difusionais podem ser extraídas a partir desses espectros. O diâmetro do semicírculo corresponde à resistência da transferência dos elétrons $R_{\text {et. }} A$ intersecção do semicírculo com o eixo $Z_{r e}$, em altas frequências $(\omega \rightarrow \infty)$ é igual à resistência da solução $R_{S}$. Uma extrapolação no círculo, em baixa frequência, origina uma interceptação correspondente $a R_{S}+R_{e t}{ }^{101}$.

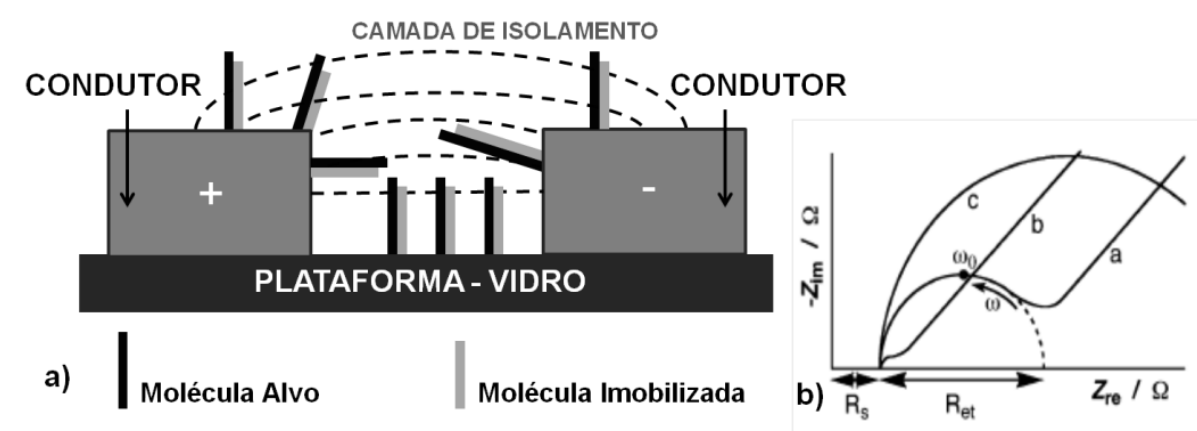

Figura 14 - Uma representação esquemática: a) eletrodo interdigitado utilizado em medidas de impedância elétrica, uma plataforma de vidro é separada por dois condutores criando uma região de isolamento entre eles, as moléculas podem se ancorar na região da plataforma ou nos condutores, quando o sinal é aplicado a resistência da transferência de cargas pode aumentar ou diminuir dependendo da molécula imobilizada e b) um típico diagrama de Nyquist representando a impedância complexa e os parâmetros relacionados, descritos acima. Adaptado de Katz et al. - $2010^{101}$.

Esses parâmetros são essenciais no estudo de dispositivos para sensoriamento a base de detecção elétrica. Além disso, a espectroscopia de impedância elétrica tem sido empregada em etapas de detecção de genossensores ${ }^{101}$. A técnica de espectroscopia de impedância elétrica, em regime AC, foi empregada como uma das técnicas de caracterização da 
construção do genossensor e na etapa de detecção da sequência alvo com o conjugado, AuNPPAMAM G4/Oligonucleotídeo, uma ilustração do sistema de medida é mostrado na Figura 15.

O impedanciômetro utilizado nas análises foi um Solartron S/1260, pertencente ao Grupo de Biofísica - IFSC/USP. Os espectros de impedância foram obtidos a temperatura de $22{ }^{\circ} \mathrm{C}$ em todas as etapas de construção do genossensor, após cada etapa de lavagem com água ultrapura, o mesmo foi submetido à caracterização elétrica por meio da espectroscopia de impedância elétrica em potenciais alternados. As análises foram obtidas em intervalo de frequência de $1 \mathrm{~Hz}$ a $1 \mathrm{MHz}$. A amplitude do potencial alternado foi de $100 \mathrm{mV}$. As medidas foram realizadas em triplicata dentro de um eppendorf® em uma solução de tampão TE (Tris HCl EDTA) 0,05 mol L ${ }^{-1}$. Essa concentração do tampão foi escolhida mediante prévio estudo.

Os eletrodos interdigitados (Figura 12) com a sequência de captura ancorada foram imersos em uma solução com 1,41 nmol $\mathrm{L}^{-1}$ de sequência alvo, 5'TTCAGAGCTGGAATAAAATTGGCGAAACCACATAAAAGTGACTGTATAGGCAG CAGGTCTAGAGAAATGGGAGAAAGGATGGGAGTGGCTCTCCAG3'. Essa solução foi aquecida a $54^{\circ} \mathrm{C}$, temperatura de annealing, por 10 minuto, para que ocorresse a $1^{\mathrm{a}}$ hibridização. Depois de esfriar e atingir a temperatura ambiente, os microeletrodos foram lavados novamente com água Milli-Q, e, incubados em uma solução com a sequência não complementar, 5' ACACCACACAACCCACCCACCCACA 3'. A solução foi aquecida a 54 $\mathrm{C}$, temperatura de annealing, por 10 minuto, para manter as mesmas condições de hibridização. Depois de esfriar e atingir a temperatura ambiente, os microeletrodos foram lavados novamente com água Milli-Q, e, posteriormente, imersos na solução contendo na 2,21 nmol L ${ }^{-1}$ do conjugado, AuNP-PAMAMG4/Oligonucleotídeo, 5'AuNP-PAMAM G4/TiolACAGTCACTTTTATGTGGTTTCGCC3'. A solução foi aquecida novamente a $54{ }^{\circ} \mathrm{C}$, por 10 minuto ( $2^{\mathrm{a}}$ hibridização), e esfriada naturalmente até atingir a temperatura ambiente. Finalmente, o genossensor foi lavado pela última vez com água ultrapura para retirada do excesso do conjugado. 


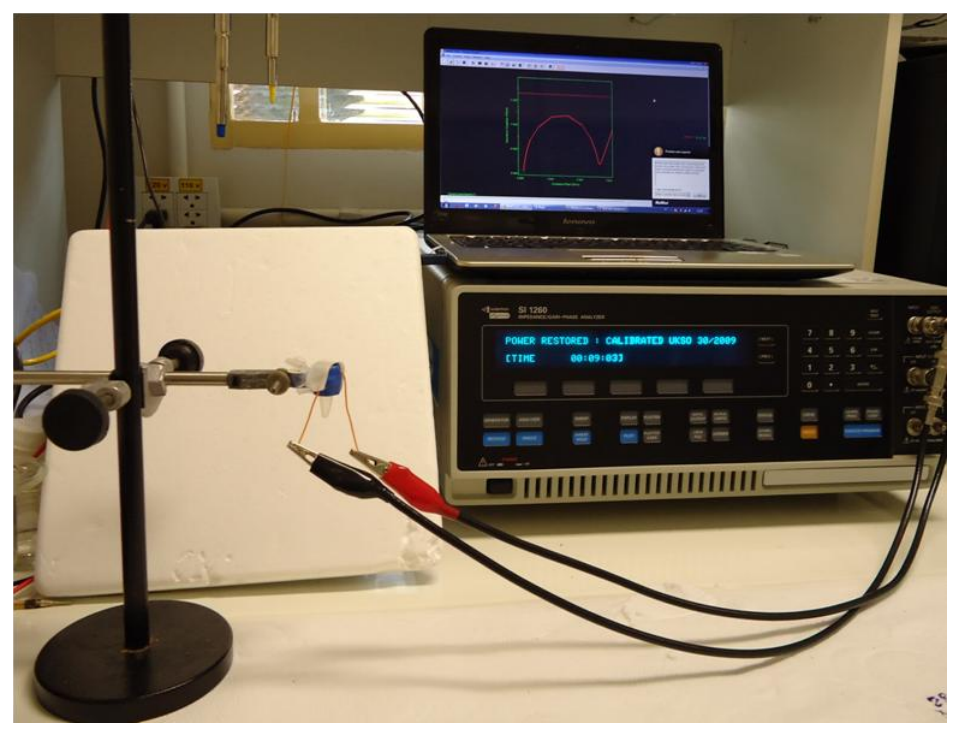

Figura 15 - Imagem do sistema utilizado nas medidas AC. Onde aparecem o notebook usado para aquisição de dados, o eppendorf® de medida e o impedanciômetro Solartron.

\subsubsection{Espectroscopia de Impedância Eletroquímica}

A espectroscopia de impedância eletroquímica consiste basicamente em analisar a impedância complexa de um sistema eletroquímico, fundamentado na aplicação de um potencial elétrico variável, por meio de um potenciostato em uma célula eletroquímica, no caso, convencional, que contém três eletrodos: eletrodo de referência (RE), contra eletrodo (CE) e eletrodo de trabalho (WE), esse sistema é ilustrado na Figura 16. Essa técnica apresenta várias vantagens como: baixo custo, rapidez na análise, facilidade de instrumentação, entre outras. Além disso, tem sido bastante utilizada em genossensores ${ }^{8-9}$. Portanto, foi empregada como uma das técnicas de caracterização da construção do genossensor e na etapa de detecção da sequência alvo com os conjugados, AuNP-PAMAM G4/Oligonucleotídeo. 


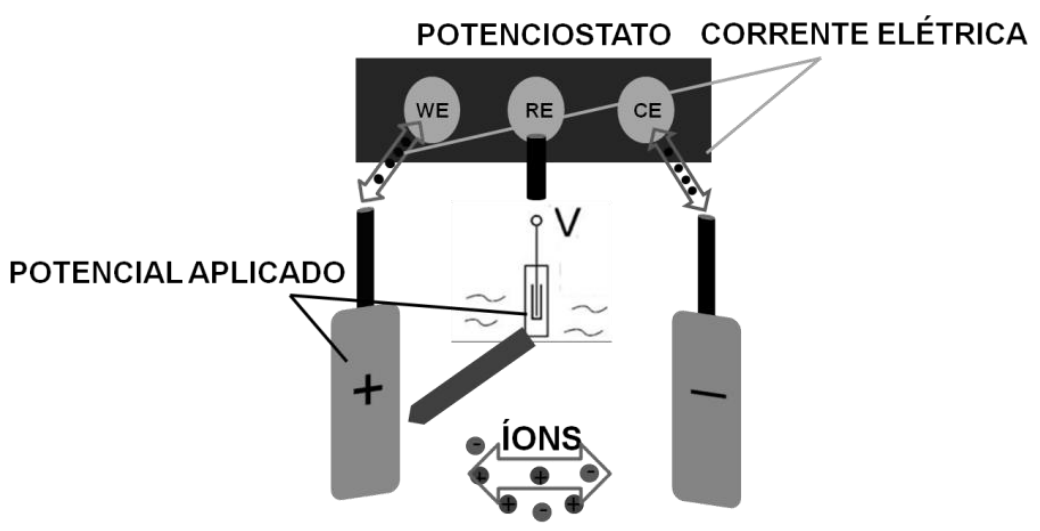

Figura 16 - Representação esquemática do sistema de medida eletroquímico: onde um potenciostato é associado a uma célula eletroquímica convencional de três eletrodos.

Os eletrodos de ouro modificados com $\mathrm{SAM}_{\text {mix }}$ descritos anteriormente foram analisados por espectroscopia de impedância eletroquímica e voltametria cíclica (resultado não mostrado), durante todas as etapas do processo de construção e detecção do genossensor, e foi utilizado hexacianoferrato de potássio (III) $\left(\mathrm{K}_{3}\left[\mathrm{Fe}(\mathrm{CN})_{6}\right]\right)$ como sonda eletroquímica. A primeira hibridização foi realizada por imersão dos eletrodos modificados, de $\mathrm{SAM}_{\text {mix }}$, em uma solução de 0,26 nmol $\mathrm{L}^{-1}$ com a sequência alvo, 5'TTCAGAGCTGGAATAAAATTGGCGAAACCACATAAAAGTGACTGTATAGGCAG CAGGTCTAGAGAAATGGGAGAAAGGATGGGAGTGGCTCTCCAG3', que foi aquecida a $54^{\circ} \mathrm{C}$ durante 10 minutos. Posteriormente, os eletrodos foram esfriados até à temperatura ambiente e lavados com água ultrapura para remover o excesso de moléculas não adsorvidas e analisados. Posteriormente, os eletrodos foram submetidos à segunda hibridização em uma solução de $2,21 \mathrm{nmol} \mathrm{L}^{-1}$ do conjugado, AuNP-PAMAM G4/Oligonucleotídeo, 5'AuNP-PAMAM GA/Tiol- ACAGTCACTTTTATGTGGTTTCGCC 3', e aquecida a $54^{\circ} \mathrm{C}$ durante 10 minutos. Em seguida, os eletrodos foram novamente resfriados a temperatura ambiente, lavados com água ultrapura para remover as moléculas adsorvidas fracamente, e, secos sob fluxo brando de $\mathrm{N}_{2}$.

Os experimentos eletroquímicos foram realizados utilizando um potenciostato eletroquímico de modelo PGSTAT40 Autolab (Eco Chemie, Utrecht, Holanda), equipado com PGSTAT-12 e GPES / FRA 4,9 software (Eco Chemie, Utrecht, Holanda) todos pertencentes ao Grupo de Biofísica - IFSC/USP. As medidas de espectroscopia de impedância eletroquímica foram realizadas em triplicata em tampão PBS $0,1 \mathrm{~mol} \mathrm{~L}^{-1} \mathrm{pH} 7,4$, contendo 5 mmol L $\mathrm{L}^{-1}$ de hexacianoferrato de potássio (III). As medidas de impedância eletroquímica foram realizadas em uma faixa de frequência de $10 \mathrm{KHz}$ a $0,1 \mathrm{~Hz}$, com uma amplitude de 
0,01 V. Os espectros foram representados como diagramas de Nyquist (-Zimag vs Zreal). Uma imagem do sistema de detecção é mostrada na Figura 17.

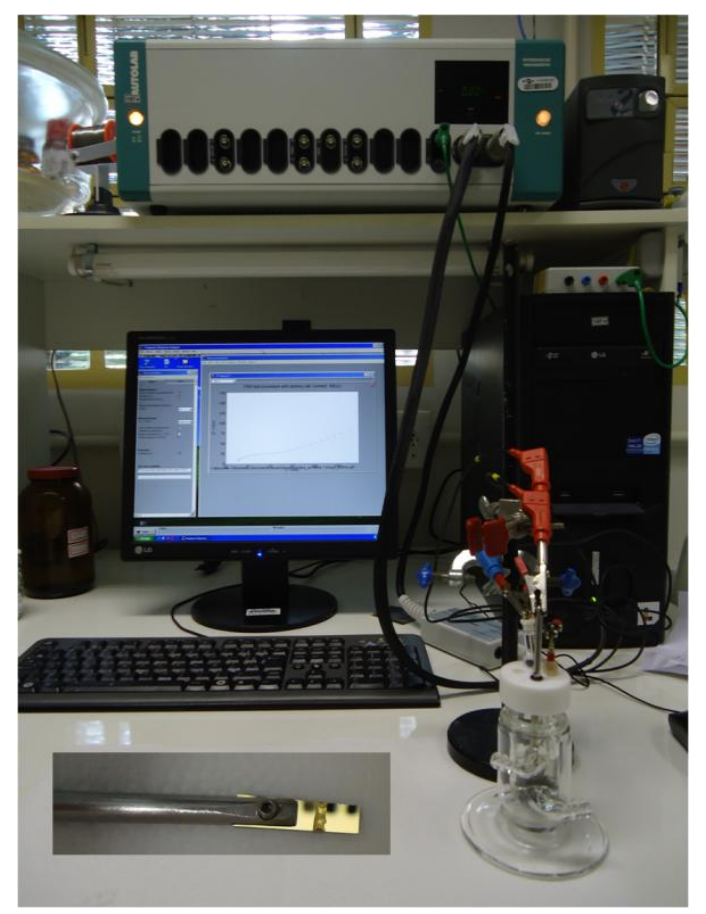

Figura 17 - Imagem do sistema utilizado na caracterização eletroquímica. Onde aparecem o computador usado para aquisição de dados, a célula eletroquímica, o potenciostato PGSTAT4O Autolab utilizados nas detecções e o eletrodo de ouro com a área delimitada utilizado na construção do genossensor.

\subsubsection{Detecção em Transistor de Efeito de Campo de Porta Estendida e Separada (SEGFET)}

A configuração do SEGFET para a detecção de DNA é composta de duas partes: um MOSFET comercial utilizado como transdutor de sinal e um eletrodo de ouro contendo a sequência de captura imobilizada atuando como porta estendida. A Figura 18 ilustra a configuração desse dispositivo e seu correspondente diagrama eletrônico. 
(a)

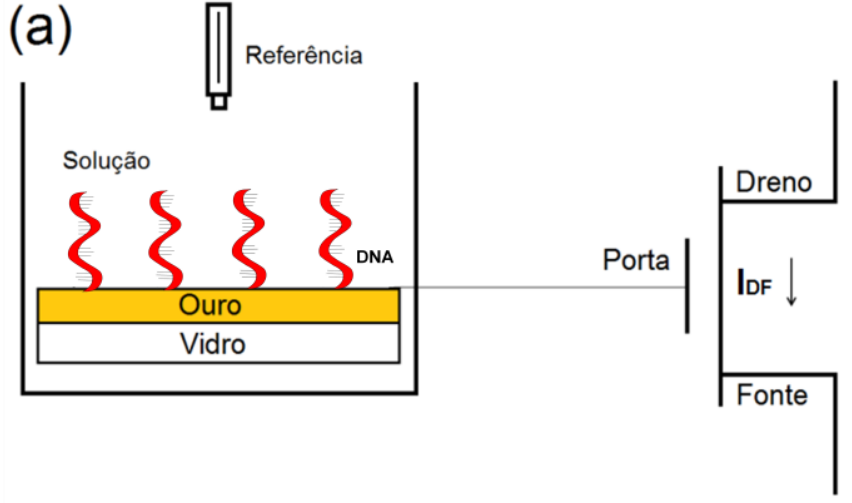

(b)

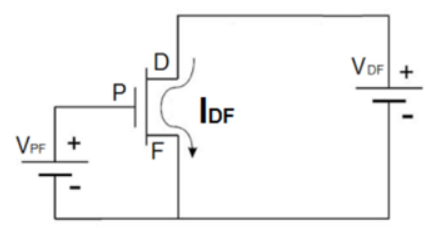

Figura 18 - a) Diagrama esquemático do dispositivo SEGFET utilizado no genossensor e b) O diagrama eletrônico do mesmo.

Nas medidas de detecção, o MOSFET foi devidamente polarizado com uma tensão dreno-fonte $\mathrm{VDS}=1,5 \mathrm{~V}$ e uma tensão porta-fonte $\mathrm{VGS}=1,5 \mathrm{~V}$. A corrente entre os eletrodos dreno-fonte ( $\mathrm{I}_{\mathrm{DS}}$ ) do MOSFET é modulada pelo potencial na superfície do filme de ouro. O SEGFET operava na região de saturação e a detecção de hibridização de DNA ocorreu mediante a medida da corrente de dreno (ID) ao longo do tempo, antes e após a incubação da porta estendida em soluções $5 \mu \mathrm{M}$ de DNA alvo, 5', GGCGAAACCACATAAAAGTGACTGT 3', por 30 minutos em temperatura ambiente para hibridização. Foram testados outros tempos de hibridização, mas para as concentrações propostas 30 minutos foi suficiente. O genossensor também foi testado em uma sequência de DNA não complementar. Todas as medidas foram realizadas em força iônica baixa (em tampão PBS 0,01 mol L ${ }^{-1}$ ) para atingir um comprimento de Debye ( $\left.\lambda \mathrm{D}\right)$ de 7,3 nm, esse comprimento está associado com o limite de detecção da técnica empregada ${ }^{102}$. 


\subsection{Síntese e caracterização das Nanopartículas de Ouro}

Para a conjugação com oligonucleotídeo, as nanopartículas de ouro foram sintetizadas na presença do PAMAM G4, visando um maior controle da forma e do tamanho, uma vez que as propriedades desse nanomaterial são fortemente associadas com as suas características morfológicas. As AuNP-PAMAM G4 antes de serem conjugadas, e sem nenhum tratamento prévio foram analisadas por TEM (Figura 19a), com o objetivo de verificarmos o tamanho e forma das AuNPs.
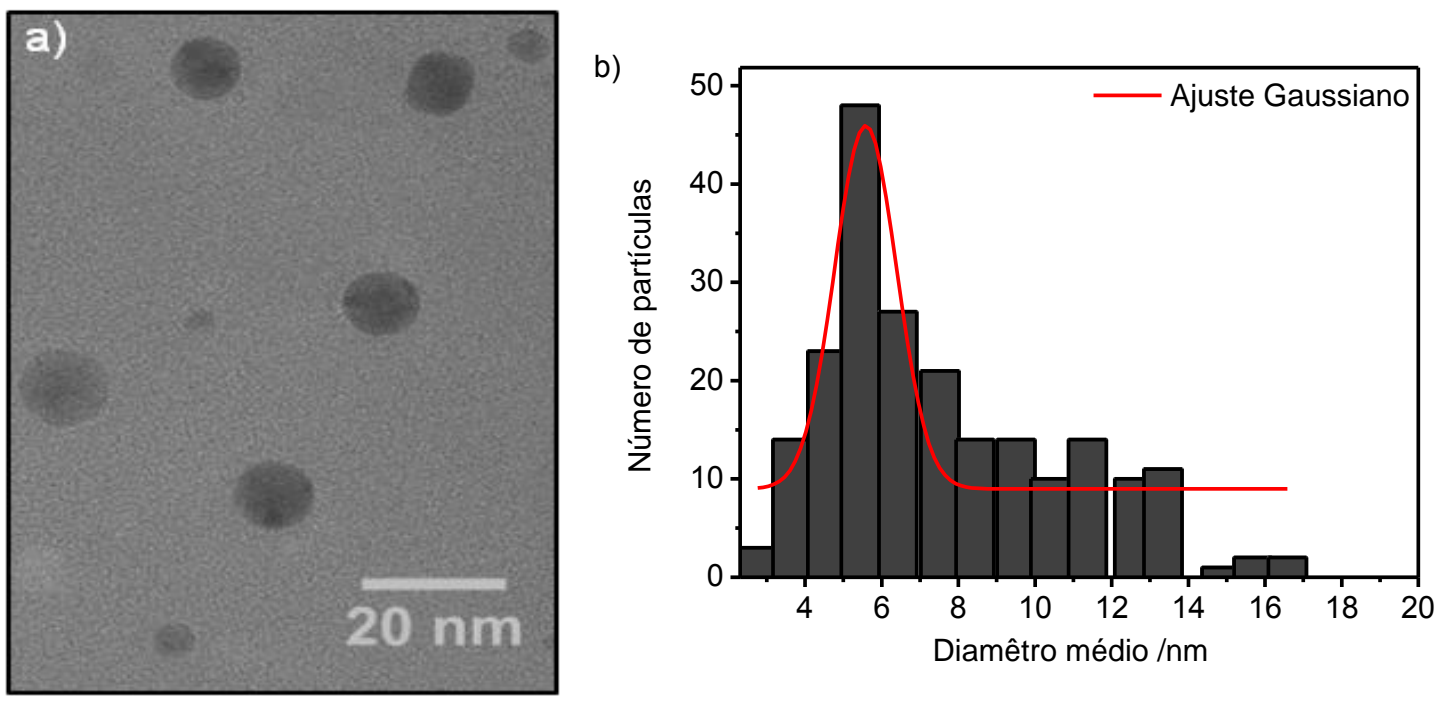

Figura 19 - a) Imagem de Microscopia eletrônica de transmissão (TEM) das nanopartículas de ouro (AuNPPAMAM G4) e b) Histograma de tamanhos das AuNP-PAMAM G4.

Como é possível observar na imagem de TEM (Figura 19a) foi verificado o formato esférico das partículas com uma boa homogeneidade. O tamanho médio das partículas e a distribuição de tamanhos foram analisados estatisticamente pela contagem de 215 partículas por meio do software de domínio publico ImageJ. O resultado dessa análise está representado na Figura 19b, que apresenta o histograma de tamanhos com o ajuste Gaussiano nos dados.

De acordo com o ajuste Gaussiano, o diâmetro médio das AuNP-PAMAM G4 foi de $6,1 \mathrm{~nm}$ e desvio médio de $\pm 0,43$, indicando que as nanopartículas também foram formadas fora da cavidade do dendrímero. Esse resultado foi esperado e em concordância com a rota de 
síntese, onde a redução ocorreu de forma lenta, visto que quando a redução é realizada de forma extremamente rápida as partículas são menores e ficam retidas na cavidade do dendrímero $^{103}$.

A ampla distribuição de tamanhos que as sínteses de nanomaterias apresentam é um problema para determinar a concentração exata que eles se encontram após a síntese. No entanto, uma estratégia plausível que utiliza a espectroscopia de UV-VIS para determinar a concentração de nanopartículas tem sido desenvolvida ${ }^{104}$.

Outra estratégia para determinar a concentração molar de suspensões de nanopartículas de ouro utiliza a razão entre número de átomos total pelo número de átomos que constitui cada nanopartícula de ouro ${ }^{105}$. O número médio de átomos que constitui cada nanopartícula de ouro pode ser estimado pela determinação do diâmetro médio (D) das nanopartículas, obtido por TEM. Com uma forma esférica e estrutura cúbica de face centrada (fcc) o número médio de átomos de ouro $(\mathrm{N})$ contidos em cada nanopartícula pode ser estimado pela Equação $3^{105}$.

$$
N=\frac{\pi}{6} \frac{\rho \cdot D^{3} \cdot N_{A}}{M}
$$

Onde $\rho$ é a densidade para o ouro fcc $\left(19,3 \mathrm{~g} \mathrm{~cm}^{3}\right), N_{A}$ é a constante de Avogadro e M é a massa atômica do ouro (197 $\left.\mathrm{g} \mathrm{mol}^{-1}\right)$. A concentração molar (C) da suspensão de nanopartículas de ouro pode então ser calculada (Equação 4) pela divisão do número total de átomos $\left(\mathrm{N}_{\text {Total }}\right)$ de ouro, referente à quantidade de ouro adicionada na síntese, pelo número de átomos de cada nanopartícula $(\mathrm{N})$ estimado anteriormente, onde V é o volume da solução, e considera-se que a redução de íons de ouro (III) tenha ocorrido completamente.

$$
C=\frac{N_{\text {Total }}}{N \cdot V \cdot N_{A}}
$$

Assim a concentração inicial da suspensão de nanopartículas de ouro pode ser calculada. Como as nanopartículas de ouro são lavadas por centrifugação antes da conjugação, é importante fazer uma curva de calibração com diferentes concentrações. É importante ressaltar que essas concentrações são apenas uma estimativa. No entanto, conhecer a concentração é de extrema importância para uma padronização experimental. Essa calibração (Figura 20b) foi obtida por meio da absorbância referente ao máximo da banda plasmônica em várias concentrações da suspensão de nanopartículas (Figura 20a). Os dados 
apresentados na Figura 20b foram ajustados linearmente, mostrando um coeficiente de correlação de 0,9921 , indicando que nessa faixa de concentração a absorção da banda de ressonância plasmônica se comporta de forma linear com a concentração. A equação da reta que relaciona esses dados está apresentada na Figura 20b.
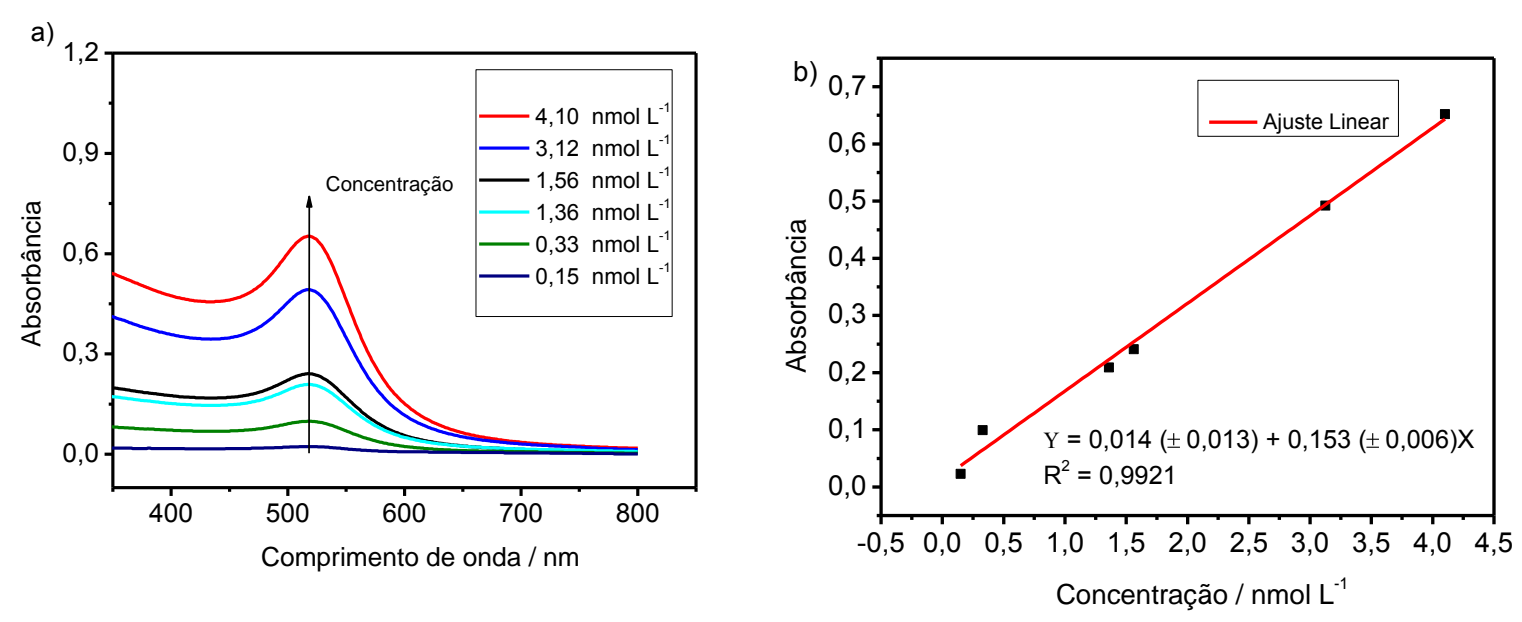

Figura 20 - a) Espectro de absorbância das AuNP-PAMAM G4 em várias concentrações e b) Gráficos dos valores de absorção máxima na banda de ressonância plasmônica de superfície $(524 \mathrm{~nm}) \mathrm{em}$ função das concentrações, ajustadas linearmente.

\subsection{Síntese e caracterização do conjugado AuNP-PAMAM G4/Oligonucleotídeo}

\subsubsection{Espectroscopia no Ultravioleta-Visível (UV-VIS)}

As AuNP-PAMAM G4 foram conjugadas com o oligonucleotídeo específico para o polimorfismo I/D do gene da ECA, como descrito anteriormente na metodologia. O conjugado AuNP-PAMAM G4/Oligonucleotídeo, o oligonucleotídeo livre, e as AuNPPAMAM G4 foram caracterizados por espectroscopia no UV-VIS (Figura 21). 


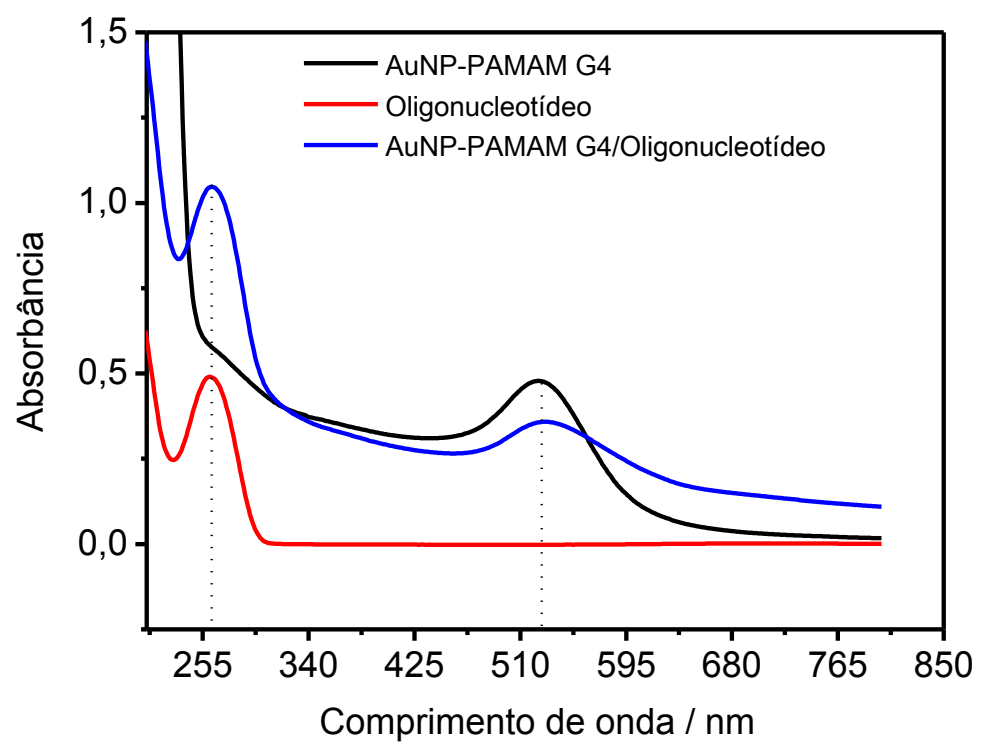

Figura 21 - Espectro de absorbância no UV-VIS das AuNP-PAMAM G4, do oligonucleotídeo e do conjugado AuNP-PAMAM G4/Oligonucleotídeo.

Na Figura 21, o espectro de absorção no UV-VIS correspondente às AuNP-PAMAM G4 (linha preta) mostra um máximo de absorção em aproximadamente $524 \mathrm{~nm}$ referente à ressonância plasmônica da superfície, que é depende do tamanho e da forma da nanopartícula $^{106}$. As nanopartículas de ouro esféricas (3 - $\left.100 \mathrm{~nm}\right)$ apresentam a absorbância máxima no UV-VIS na faixa de 510 a $570 \mathrm{~nm}^{2}$. Absorções na região de $520 \mathrm{~nm}$ estão associadas com um diâmetro entre 10 a $15 \mathrm{~nm}$, o que foi verificado nesse trabalho, por TEM e DLS $^{104}$. Os ácidos nucleicos, DNA e RNA apresentam uma absorbância intensa na região entre 240 e $275 \mathrm{~nm}$, referentes aos anéis de pirimidina e purina das bases nitrogenadas ${ }^{107}$. O espectro de UV-VIS do oligonucleotídeo (Figura 21, linha vermelha) apresentou uma intensa absorção em 260 nm, referente às bases nitrogenadas. Ainda na Figura 21, o espectro do conjugado AuNP-PAMAM G4/Oligonucleotídeo apresentou de maneira intensa e bem definidas, as duas bandas de absorção, aproximadamente em $260 \mathrm{~nm}$ e $524 \mathrm{~nm}$, convenientes com a banda de absorção das AuNP-PAMAM G4 e do oligonucleotídeo, sugerindo o sucesso da conjugação. 


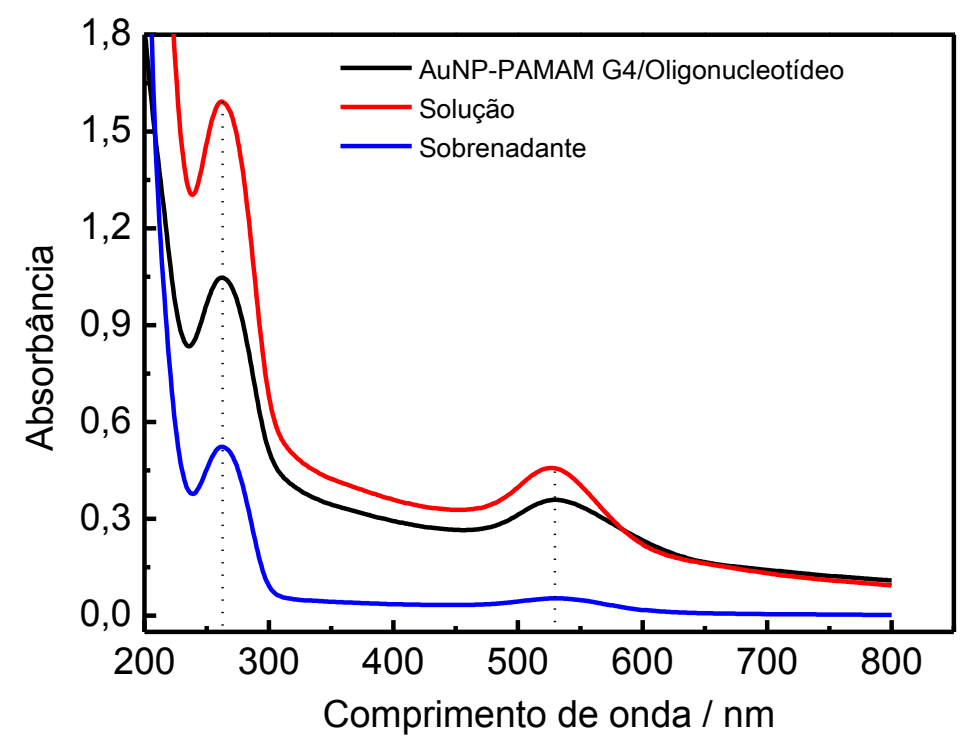

Figura 22- Espectro de absorbância no UV-VIS da solução de síntese, do sobrenadante e do precipitado ressuspendido (conjugado AuNP-PAMAM G4/Oligonucleotídeo).

Na Figura 22 são mostrados os espectros da solução de síntese após sua finalização, o precipitado ressuspendido e o sobrenadante. Após a centrifugação, o espectro do precipitado (linha preta) continuou exibindo a banda de absorção das AuNP-PAMAM G4 com um pequeno deslocamento de aproximadamente $7 \mathrm{~nm}$ (de 524 para $531 \mathrm{~nm}$ ) e uma banda bem definida do oligonucleotídeo em $260 \mathrm{~nm}$, indicando a formação do conjugado AuNPPAMAM G4/Oligonucleotídeo. Esse deslocamento na banda de absorção das nanopartículas está associado com alterações em sua superfície, e possíveis conjugações. Além disso, o espectro do sobrenadante (Figura 22, linha azul) mostrou bandas de absorção com intensidades mais baixas, quando comparadas com as bandas no espectro do precipitado ressuspendido, o que indica que uma boa quantidade de oligonucleotídeo conjugou com as AuNPs, de acordo com o espectro de solução (linha vermelha) que mostra a quantidade excessiva colocada na síntese para a conjugação. No entanto, outros experimentos de caracterização com DLS e FTIR foram realizados para corroborar esses resultados e agregar um entendimento melhor da interação entre as AuNP-PAMAM G4 e o oligonucleotídeo. 


\subsubsection{Espalhamento Dinâmico de Luz (DLS)}

As medidas de DLS foram realizadas para analisar principalmente a distribuição de tamanho de nanopartículas e conjugados envolvendo nanopartículas e biomoléculas, sendo também uma técnica para investigar a interação entre as moléculas. Na Figura 23 são mostradas as distribuições de tamanho obtidas por DLS das AuNP-PAMAM G4 e do conjugado AuNP-PAMAM G4/Oligonucleotídeo. O oligonucleotídeo livre não foi analisado porque seu tamanho não se encontra no limite de detecção do equipamento. $\mathrm{O}$ diâmetro médio das AuNP-PAMAM G4 (Figura 23a) foi de 10,4 \pm 0,71, esse diâmetro foi superior ao encontrado por TEM, como mencionado anteriormente, pelo fato do DLS ser baseado no diâmetro hidrodinâmico das partículas ${ }^{88}$. O conjugado AuNP-PAMAM G4/Oligonucleotídeo (Figura 23b) apresentou um diâmetro médio de 17,44 $\mathrm{nm} \pm 0,93$, valor que sugere a ocorrência de conjugação. Além disso, esse diâmetro médio era esperado, uma vez que a sequência de oligonucleotídeo conjugada com as nanopartículas tem 25 bases, e entre cada base existe um espaço aproximado de 0,34 nm. Portanto, com 25 bases a sequência apresentaria, aproximadamente, 8,50 nm de comprimento linear. No entanto, o tamanho real é atribuído à natureza do DNA, e é conhecido que DNAs sintéticos apresentam uma leve torção ficando em formato $Z$, com redução dos espaços entre os giros e as bases do DNA ${ }^{108}$. Portanto, o seu tamanho real é menor do que o seu tamanho teórico.
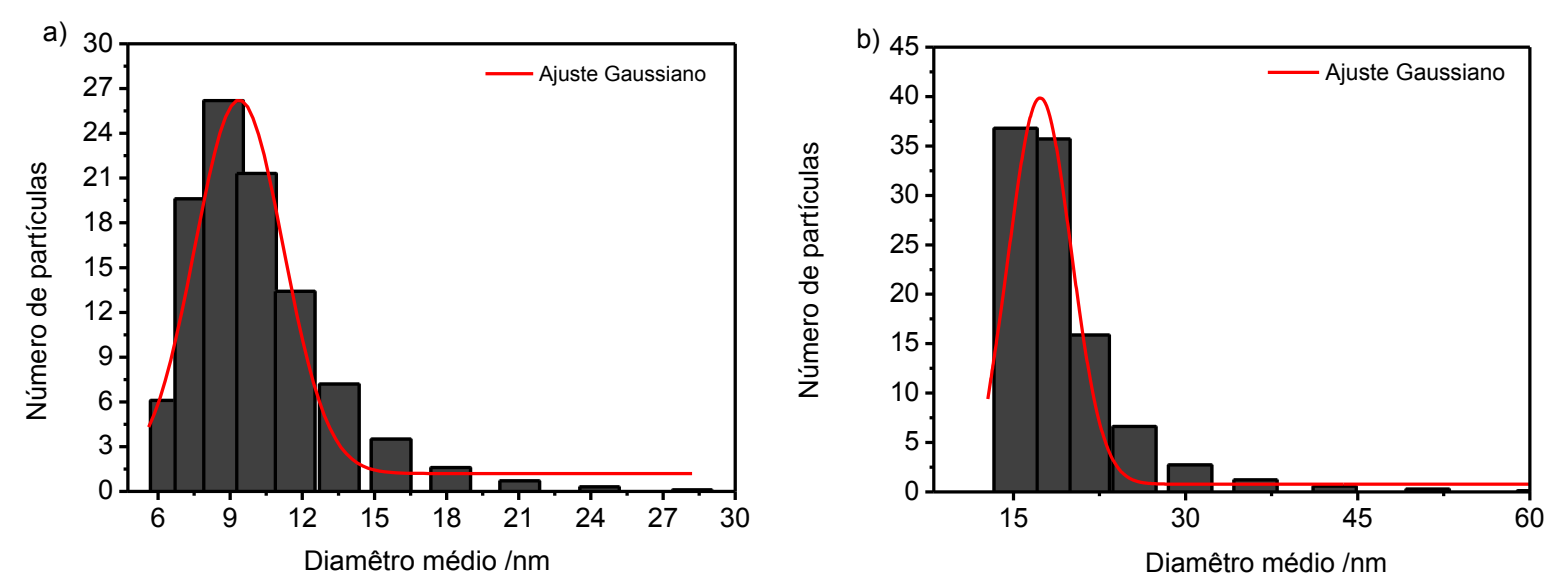

Figura 23 - Histogramas da distribuição de tamanhos obtidos por DLS para as amostras a) AuNP-PAMAM G4 e b) AuNP-PAMAM G4/Oligonucleotídeo. As medidas foram realizadas em água ultrapura, $\mathrm{pH}$ entre 6,8 e 7,0 . 


\subsubsection{Potencial Zeta}

O potencial zeta das amostras AuNP-PAMAM G4, Oligonucleotídeo livre e AuNPPAMAM G4/Oligonucleotídeo estão apresentados na Tabela 6. Com descrito na metodologia de síntese do conjugado no tópico 4.2.2, as nanopartículas de ouro foram lavadas duas vezes e ressuspendidas em água ultrapura antes de serem submetidas à conjugação. Esse processo torna as nanopartículas muito instáveis e aumenta a velocidade de agregação, diminuindo os grupamentos aminas do PAMAM G4 que estavam protonados. Esse fato é evidenciado pelo baixo valor de potencial $\zeta$ das AuNP-PAMAM G4. O potencial zeta do oligonucleotídeo livre se mostrou altamente negativo, indicando estabilidade. Contudo, o potencial $\zeta$ do conjugado AuNP-PAMAM G4/Oligonucleotídeo indica que ocorreu um equilíbrio entre as cargas superficiais dos compostos perto da faixa de estabilidade, pois potenciais acima de $\pm 30 \mathrm{mV}$ já acrescentam uma ótima estabilidade aos compostos ${ }^{109}$.

Tabela 6 - Potencial Zeta obtido para as amostras: AuNP-PAMAM G4, Oligonucleotídeo livre e AuNPPAMAM G4/Oligonucleotídeo, em água ultrapura $\mathrm{pH}=7,0$.

\begin{tabular}{ll}
\hline Amostra & Potencial $\zeta / \mathbf{m V}$ \\
\hline AuNP-PAMAM G4 & $+2,88$ \\
Oligonucleotídeo livre & $-41,00$ \\
AuNP-PAMAM G4/Oligonucleotídeo & $-24,50$ \\
\hline
\end{tabular}

\subsubsection{Espectroscopia no Infravermelho (FTIR)}

Com a finalidade de conhecer melhor a interação entre a nanopartícula e o oligonucleotídeo, os espectros de FTIR (Figura 24) foram obtidos das amostras AuNPPAMAM G4, Oligonucleotídeo livre e AuNP-PAMAM G4/Oligonucleotídeo. Os espectros foram normalizados com a mesma linha de base e pela concentração. 


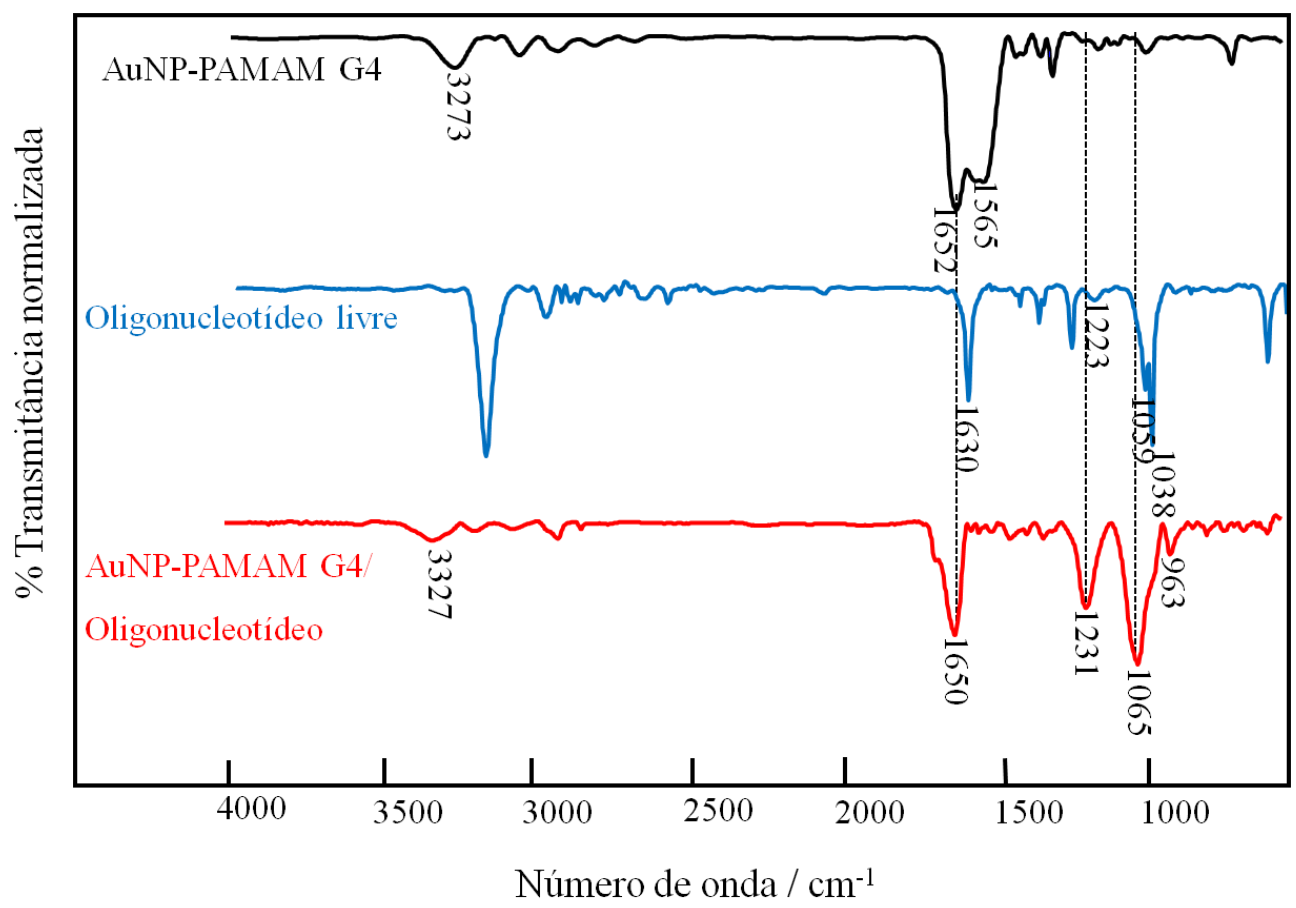

Figura 24 - Espectros de FTIR das amostras AuNP-PAMAM G4, Oligonucleotídeo livre e AuNP-PAMAM G4/Oligonucleotídeo.

No espectro das AuNP-PAMAM G4 (linha preta) as bandas são referentes ao estabilizante PAMAM G4. A transmissão em $3273 \mathrm{~cm}^{-1}$ é relacionada com estiramento simétrico e assimétrico do grupo $\mathrm{NH}_{2}$. As duas bandas em formato dublete 1565 e $1652 \mathrm{~cm}^{-1}$ são referentes ao estiramento $\mathrm{C}=\mathrm{O}$ e a deformação $\mathrm{N}-\mathrm{H} /$ estiramento $\mathrm{C} / \mathrm{N}$ das amidas presentes na cavidade do PAMAM G4 ${ }^{110}$. No espectro do oligonucleotídeo livre (linha azul) a banda em $1630 \mathrm{~cm}^{-1}$ corresponde aos grupos aminas ${ }^{110,111}$ presentes nas bases nitrogenadas do DNA (1700 a $1500 \mathrm{~cm}^{-1}$ ). As bandas em 1059 e $1038 \mathrm{~cm}^{-1}$ são tipicamente atribuídas a vibrações de ribose (C-C açúcar) ${ }^{111}$ presente na molécula de DNA e associadas com grupos sulfitos ${ }^{110}$ que estão na modificação no grupo fosfato do oligonucleotídeo (-S=P). Ainda no espectro do oligonucleotídeo livre, a banda em $1223 \mathrm{~cm}^{-1}$ é relacionada com vibrações do estiramento assimétrico do grupo fosfato $\left(\mathrm{PO}^{2-}\right)^{111}$. A baixa intensidade é também um indicador da modificação, que esse grupo apresenta devido às interações entre os três elementos, $\mathrm{S}=\mathrm{P}=\mathrm{O}$, uma vez que as duplas ligações oscilam entre o $\operatorname{compostos}^{30}$. No espectro do conjugado AuNP-PAMAM G4/Oligonucleotídeo (linha vermelha) a vibração assimétrica do grupo fosfato $\mathrm{PO}^{2-}$ apresenta uma grande alteração, tanto na intensidade quanto no deslocamento de $8 \mathrm{~cm}^{-1}$ (de 1223 para $1231 \mathrm{~cm}^{-1}$ ). Essas alterações corroboram com a proposta de interação nesse grupo. A banda em $1065 \mathrm{~cm}^{-1}$ no espectro do conjugado corresponde à junção das duas bandas do oligonucleotídeo livre referentes à vibração da 
ribose e grupos sulfitos em 1059 and $1038 \mathrm{~cm}^{-1}$, que também indicam uma nova interação nesses grupos ${ }^{110-111}$. A absorção em $963 \mathrm{~cm}^{-1}$ é uma indicação da presença de $\mathrm{DNA}^{111} \mathrm{e}$ a banda em $1650 \mathrm{~cm}^{-1}$ é uma sobreposição das bandas da AuNP-PAMAM G4 em 1652 e 1565 $\mathrm{cm}^{-1}$ com a banda do oligonucleotídeo em $1630 \mathrm{~cm}^{-1}$. As principais atribuições descritas estão sumarizadas na Tabela 7. Pela análise dos espectros de FTIR das amostras é possível concluir que a conjugação das nanopartículas de ouro com o oligonucleotídeo foi alcançada. Essa interação ocorreu pelas amidas no interior do dendrímero das nanopartículas com o grupo fosfato modificado do oligonucleotídeo. No entanto, com o intuito de investigar a funcionalidade do conjugado AuNP-PAMAM G4/Oligonucleotídeo e saber se os oligonucleotídeos estavam funcionais, mesmo depois de terem sido complexados com as nanopartículas, esses conjugados foram utilizados em PCR em tempo real.

Tabela 7 - Principais atribuições propostas para as bandas encontradas na análise por espectroscopia no infravermelho (FTIR).

\begin{tabular}{llllll}
\hline $\begin{array}{l}\text { AuNP-PAMAM } \\
\text { G4 }\end{array}$ & Atribuições & $\begin{array}{l}\text { Oligonucleotídeo } \\
\text { Livre }\end{array}$ & Atribuições & $\begin{array}{l}\text { AuNP-PAMAM } \\
\text { G4/Oligonucleotídeo }\end{array}$ & Atribuições \\
\hline $3273 \mathrm{~cm}^{-1}$ & Amina $\mathrm{NH}_{2}$ & $1223 \mathrm{~cm}^{-1}$ & Fosfato $\mathrm{PO}_{2}$ & $1231 \mathrm{~cm}^{-1}$ & Fosfato $\mathrm{PO}_{2}$ \\
$1652 \mathrm{~cm}^{-1}$ & Amida secundária & $1630 \mathrm{~cm}^{-1}$ & Aminas & $1650 \mathrm{~cm}^{-1}$ & Amidas e Aminas \\
$1565 \mathrm{~cm}^{-1}$ & Amida primária & $1059 \mathrm{e}^{-1038 \mathrm{~cm}^{-1}}$ & Ribose $(\mathrm{C}-\mathrm{C})$ & $1065 \mathrm{~cm}^{-1}$ & Ribose (C-C) \\
\hline
\end{tabular}

\subsubsection{Reação em Cadeia da Polimerase em Tempo Real}

A Reação em Cadeia da Polimerase em tempo real é uma técnica frequentemente utilizada para amplificar fragmentos de DNA, basicamente utilizando uma DNA polimerase e sondas fluorescentes que se intercalam na dupla fita de DNA, e o resultado da amplificação é simultâneo com a reação. Esta técnica é aplicada no sequenciamento de material genético para diagnósticos ${ }^{112-114}$. Pesquisadores desenvolveram uma combinação de sequenciamento capilar e PCR em tempo real utilizando nanopartículas de ouro, que foram capazes de identificar diversas alterações do DNA em regiões significativas de DNA genômico humano, essas alterações são associadas com doenças relacionada a idade ${ }^{114}$.

A PCR em tempo real foi realizada com o AuNP-PAMAM G4/Oligonucleotídeo e com primer controle, oligonucleotídeo sem nanopartícula, que foram utilizados em 
concentrações equivalentes para posterior análise, conforme a Tabela 5. Observamos na Figura 25 os espectros de fluorescência, que correlacionam as unidades de fluorescência com o número de ciclos da amplificação. As análises foram realizadas pelo software CFX Manager ${ }^{\mathrm{TM}}$ da BIO-RAD. A curva do SYBR (linha preta) é a linha de base do fator fluorescente utilizado na reação. Quando cada curva da amostra intersecciona essa linha e continua aumentando proporcionalmente aos ciclos, é indicativo de que esteja ocorrendo amplificação do DNA molde. As quatro reações mostradas na Figura 25 foram realizadas em duplicata e foram amplificadas com sucesso pelos primers controles e também pelos

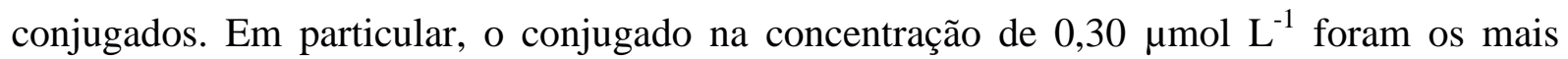
eficientes, comparados até mesmo com os primers controles. Os conjugados amplificaram primeiro, a partir do ciclo 25,61, e os controles amplificaram a partir dos ciclos 27,69 e 29,50. O AuNP-PAMAM G4/Oligonucleotídeo além de amplificar o DNA, apresentou um desempenho melhor quando comparados aos primers controles, os quais estavam sem as nanopartículas. Esses resultados indicam que o oligonucleotídeo, após a conjugação com as nanopartículas de ouro, permaneceu estável e funcional. Dessa maneira, o conjugado AuNPPAMAM G4/Oligonucleotídeo foi empregado na construção do genossensor.

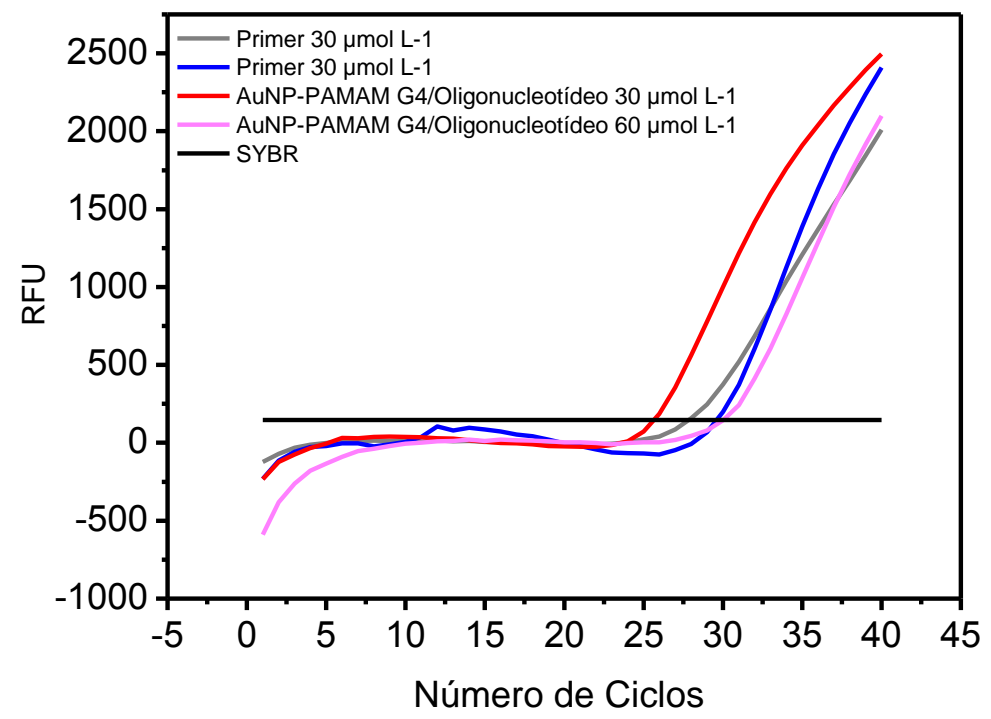

Figura 25 - Espectros de fluorescência da PCR em tempo real. Unidades de fluorescência (RFU) em função do

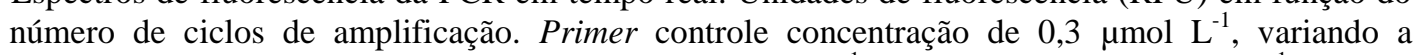
concentração de DNA molde, linha cinza $0,15 \mu$ mol $\mathrm{L}^{-1}$ e linha azul $0,30 \mu \mathrm{mol} \mathrm{L} \mathrm{L}^{-1}$. AuNPPAMAM/Oligonucleotídeo, linha vermelha $0,15 \mu$ mol $\mathrm{L}^{-1}$ DNA molde e $0,30 \mu \mathrm{mol} \mathrm{L^{-1 }}$ de conjugado e linha rosa $0,30 \mu \mathrm{mol} \mathrm{L}{ }^{-1}$ DNA molde e $0,60 \mu \mathrm{mol} \mathrm{L}^{-1}$ de conjugado. 


\subsection{Desenvolvimento e caracterização do genossensor utilizando o AuNP-PAMAM G4/Oligonucleotídeo}

\subsubsection{Espectroscopia de Impedância Elétrica}

A caracterização por espectroscopia de impedância elétrica foi empregada na etapa de genossensoriamento do dispositivo construído em modelo de hibridização sanduíche, utilizando com sonda marcada o conjugado AuNP-PAMAM G4/Oligonucleotídeo. A escolha da caracterização de perfil elétrico nas detecções do polimorfismo foi aplicada com o propósito de estudar uma nova técnica de detecção, visto que, existe um interesse saturado em genossensores com detecção eletroquímica ${ }^{50,115-118}$. Assim, a caracterização elétrica na etapa de detecção é de caráter inovador.

Os espectros de impedância estão em diagramas de Nyquist e representam a componente real (Z') e a componente imaginária (Z’) da impedância complexa. Neste diagrama podemos visualizar a forma polar da impedância complexa ${ }^{119}$. O semicírculo formado representa um processo de condução. A região próxima de $Z$ ' $=Z$ ' ' $=0$ é relativa a altas frequências e quanto mais distante desta região menor será a frequência associada ${ }^{119}$. No limite $\omega \rightarrow 0$ temos $Z$ ' $\rightarrow R$, o efeito resistivo, e Z' $\rightarrow 0$. Previamente, foi realizado um estudo da resistência elétrica do eletrodo interdigitado (utilizado na construção do genossensor) em concentrações diferentes do tampão TE, uma vez que o mesmo é utilizado nas medidas. Esses resultados estão mostrados na Figura 26 e observa-se que aumentando a concentração, a resistividade do sistema diminui. Para não influenciar nos resultados, foi utilizada a concentração de $0,05 \mathrm{~mol} \mathrm{~L}^{-1}$ do tampão em todas as medidas, visando uma análise adequada do sistema.

Nos espectros de impedância do genossensor, Figura 27, a resistência do genossensor diminui de acordo com as etapas de hibridização, o que é atribuído às cargas superficiais do DNA que facilitaram a permissividade da corrente. Observando a resistência do genossensor após o mesmo ser colocado para hibridizar com uma sequência que não é complementar (sequência negativa) com a sua sequência imobilizada e, portanto não hibridizando, a resistência não alterou significativamente. Esse fato é importante no genossensoriamento para evitar o risco de falso-positivo. Na etapa de detecção da sequência que apresentava a região do polimorfismo com a nanopartícula, a resistência do dispositivo diminuiu pela metade, 
indicando que o conjugado, AuNP-PAMAM G4/Oligonucleotídeo, hibridizou na sequência alvo, a qual já estava ancorada no eletrodo. Assim, o uso do conjugado AuNP-PAMAM G4/Oligonucleotídeo na fase de detecção do genossensor amplificou o sinal elétrico, diminuindo a resistência do dispositivo.
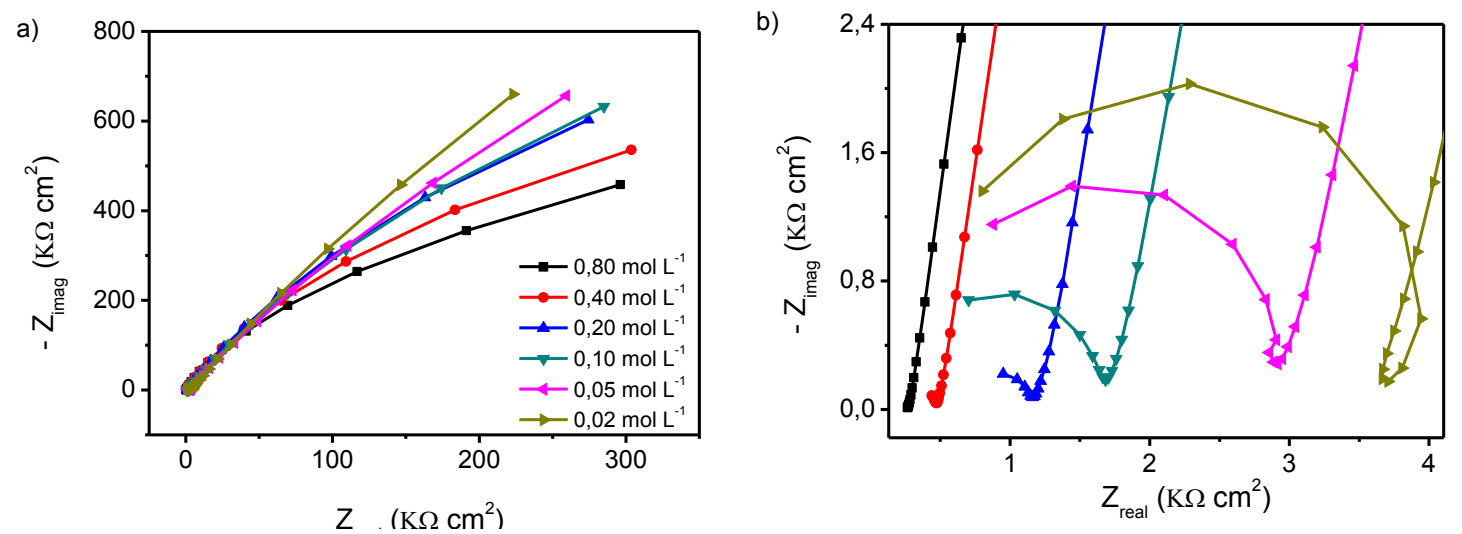

Figura 26 - a) Diagrama de Nyquist representando a impedância complexa de concentrações diferentes de tampão TE e b) Diagrama de Nyquist com zoom na região de 0 a $4 \mathrm{~K} \Omega \mathrm{cm}^{2}$ da componente real da impedância. As análises foram realizadas em tampão TE $0,05 \mathrm{~mol} \mathrm{~L}^{-1} \mathrm{pH}=7,4$.
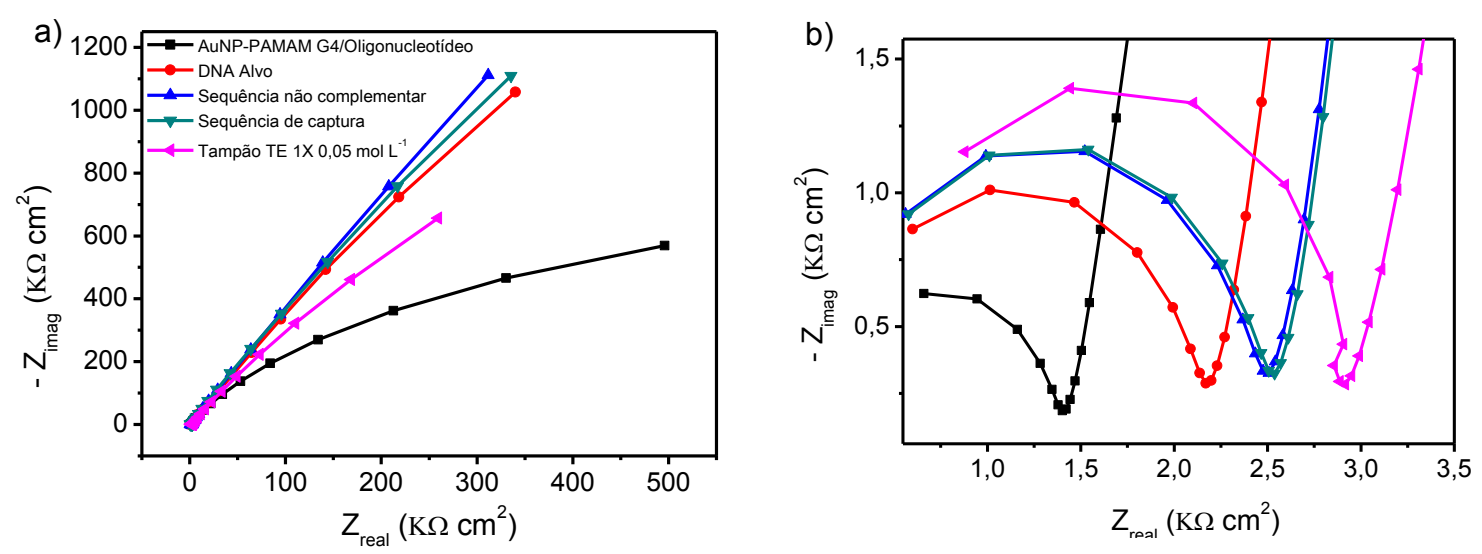

Figura 27 - a) Diagrama de Nyquist representando a impedância complexa das etapas de construção e detecção do genossensor e b) Diagrama de Nyquist com zoom na região de 0 a $3,5 \mathrm{~K} \Omega \mathrm{cm}^{2}$ da componente real da impedância. As análises foram realizadas em tampão TE $0,05 \mathrm{~mol} \mathrm{~L}^{-1} \mathrm{pH}=7,4$. 


\subsubsection{Espectroscopia de Impedância Eletroquímica}

Espectroscopia de impedância eletroquímica tem sido usada em genossensores para monitorar a transferência de elétrons que ocorre durante o processo de hibridização do $\mathrm{DNA}^{120}$. Essa detecção só é possível porque as moléculas que formam uma película sobre a superfície do eletrodo, modulam o ambiente elétrico e eletroquímico da interface, que pode ser detectado sob a forma de alterações nas capacitâncias ou nas taxas de transferência de eletrônica $^{121}$. Além disso, a repulsão eletrostática e o impedimento estérico interfacial entre uma carga de livre difusão de espécies redox e as cargas do grupo fosfato do DNA são capazes de mudar a interface do eletrodo e, consequentemente, alterar as resistências e a capacitância durante a detecção ${ }^{122-123}$.

Os espectros de impedância eletroquímica de cada etapa do genossensor (Figura 28) foram obtidos antes e depois de cada hibridização. Na etapa final (segunda hibridização) foram avaliadas duas situações, no primeiro caso foi utilizado o conjugado AuNP-PAMAM G4/Oligonucleotídeo, e no outro o genossensor apenas com a sequência complementar sem a nanopartícula. Os resultados estão apresentados na Figura 29 como diagramas de Nyquist. As medidas foram realizadas com potencial $0,40 \mathrm{~V}$ em regime $\mathrm{AC}$ e potencial de $0,01 \mathrm{~V}$ e na faixa de frequência de $0.1 \mathrm{~Hz}$ a $10 \mathrm{kHz}$ em tampão PBS, pH 7,4 contendo $5 \mathrm{mM}$ $\left[\mathrm{Fe}(\mathrm{CN})_{6}\right]^{3-/ 4-}$.

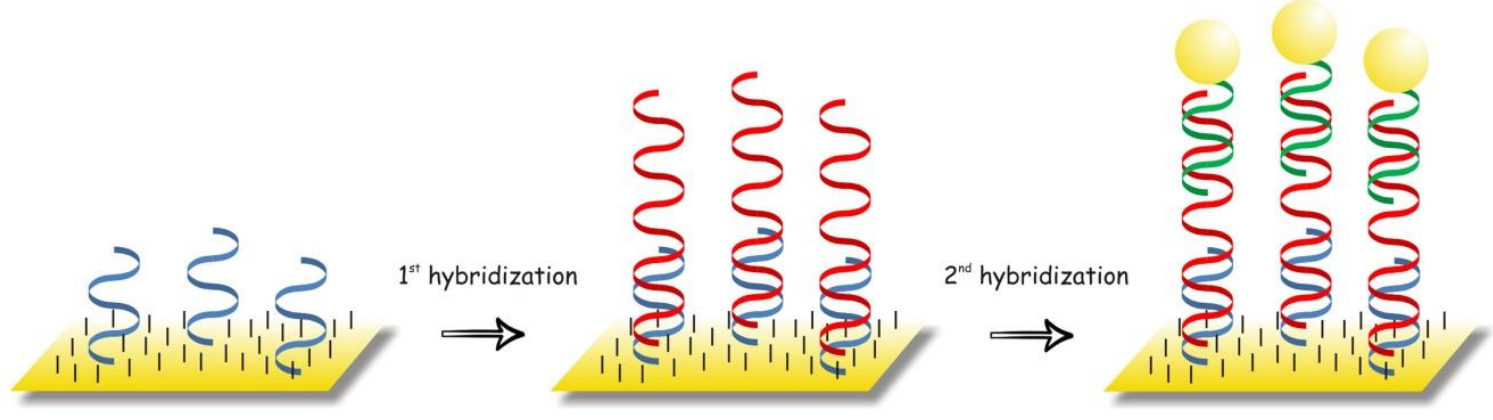

Figura 28 - Etapas de detecção e construção do genossensor em modelo de hibridização sanduíche. Imobilização por meio de $\mathrm{SAM}_{\text {mix }}$ (sequência de captura + 2-ME), primeira hibridização com a sequência alvo e segunda hibridização com o AuNP-PAMAM G4/Oligonucleotídeo. 

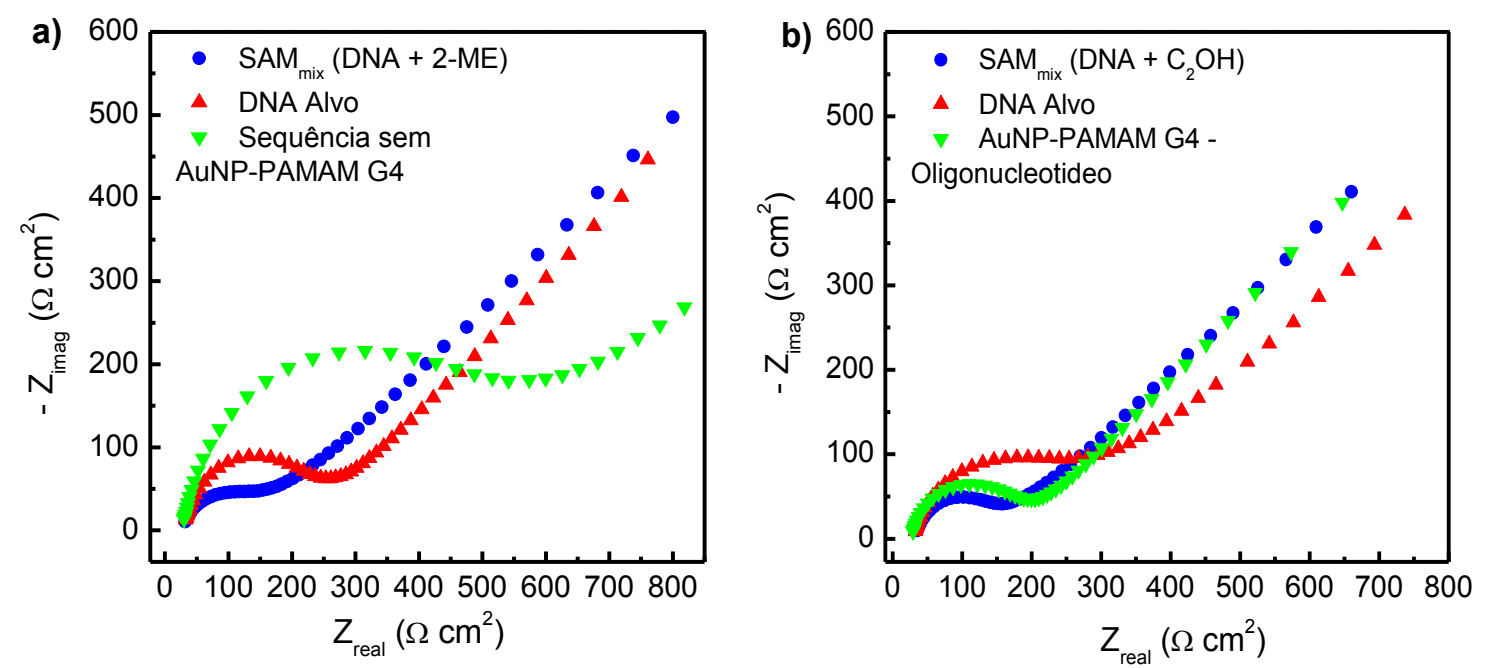

Figura 29 - a) Diagrama de Nyquist representando a impedância complexa do ensaio sem a utilização dos AuNP-PAMAM G4/Oligonucleotídeo no genossensor e b) Diagrama de Nyquist representando a impedância complexa das etapas de construção do genossensor e detecção do AuNP-PAMAM G4/Oligonucleotídeo. As análises foram realizadas em tampão PBS, $\mathrm{pH}=7,4$ contendo $5 \mathrm{mM}$ $\left[\mathrm{Fe}(\mathrm{CN})_{6}\right]^{3-/ 4-}$.

Os espectros de impedância da Figura 29 mostram os diagramas de Nyquist para cada etapa da construção e hibridização do genossensor. Os espectros referentes às sequências de captura $\left(\mathrm{SAM}_{\text {mix }}\right.$ : DNA + 2-ME) em vermelho, e a primeira hibridização com a sequência alvo em azul, mostram um aumento no semicírculo na região de alta frequência, o que indica que o processo de transferência de elétrons foi dificultado devido a primeira hibridização, ocasionando um aumento da resistência de transferência de carga ${ }^{83,124}$. No entanto, a maior diferença foi observada após a segunda hibridização com e sem a utilização do AuNPPAMAM G4/Oligonucleotídeo na etapa de detecção do polimorfismo, como mostra os espectros em verde. Os espectros em verde da Figura 29 evidenciam uma diferença significativa entre as resistências de transferência de cargas do genossensor com e sem o AuNP-PAMAM G4/Oligonucleotídeo. A Figura 29a mostra um semicírculo na região de alta frequência do diagrama de impedância, indicando um comportamento de bloqueio para a sonda $\left[\mathrm{Fe}(\mathrm{CN})_{6}\right]^{3-/ 4-}$, em comparação com a Figura $29 \mathrm{~b}$, no mesmo processo, quando utilizouse o conjugado AuNP-PAMAM G4/Oligonucleotídeo. Neste caso, a nanopartícula de ouro presente no conjugado mostrou-se capaz de melhorar a transferência de carga da sonda eletroquímica do seio da solução à superfície do eletrodo, o que resultou em menor resistência de transferência de carga no genossensor.

As etapas de construção do genossensor combinadas com a técnica de impedância eletroquímica e as mudanças observadas na $R_{c t}$ representam uma alternativa simples para a 
análise da hibridização de sequências pequenas de DNA. No entanto, a confirmação da formação secundária da sequência de DNA complementar é muito importante, especialmente quando duas outras hibridizações estão envolvidas. Quando a sequência alvo foi ancorada sobre a sequência de captura $\left(\mathrm{SAM}_{\text {mix }} \mathrm{DNA}+2-\mathrm{ME}\right)$ na superfície do eletrodo, uma segunda camada foi formada, e os grupos fosfato carregados negativamente sobre a estrutura do DNA alvo geraram repulsão elétrica no marcador de carga negativa redox, inibindo o processo de transferência de carga interfacial e resultando em aumento de $\mathrm{R}_{\mathrm{ct}}$. Neste caso, a repulsão elétrica entre os grupos fosfato carregados da estrutura do DNA alvo e da sonda eletroquímica $\left(\left[\mathrm{Fe}(\mathrm{CN})_{6}\right]^{3-/ 4-}\right)$ ocasionou o aumento da resistência de transferência de carga de $142 \Omega$ para $259 \Omega$ após a primeira hibridização (Figura 29a), e de $159 \Omega$ a $203 \Omega$ no genossensor (Figura 29b) na mesma etapa.

Com o intuito de observar a melhor concentração de sequência alvo para fazer a detecção no genossensor, foi realizado um estudo em concentrações diferentes de sequência alvo, como mostra os espectros da Figura 30. Os resultados foram observados em termos de transferência de cargas da sonda $\left[\mathrm{Fe}(\mathrm{CN})_{6}\right]^{3-/ 4-}$, de acordo com a quantidade de sequências alvo hibridizadas. A resistência à transferência de carga aumenta proporcionalmente ao aumento da concentração de sequência alvo. As concentrações de sequência alvo de 30 e 40 nmol L ${ }^{-1}$ apresentaram a maior resistência de transferência de carga quando comparadas com as outras concentrações. Neste caso, o valor máximo da parte imaginária da impedância, $\mathrm{Z}_{\text {imag }}$ do genossensor foi de $445 \Omega$. Provavelmente nessas concentrações há uma saturação entre as ligações das duas sequências complementares, isto é, todas as sequências de captura disponíveis na superfície do eletrodo foram hibridizadas pela sequência alvo deixando constante o valor de resistência de carga. No entanto, a concentração mínima que pode promover uma modificação na transferência de elétrons foi de $10 \mathrm{nmol} \mathrm{L}^{-1}$ a qual apresentou um valor de transferência de carga de $208 \Omega$ sendo duas vezes menor que a observada para uma concentração elevada. Esses resultados indicam que provavelmente uma interação eletrostática, entre a sequência de captura e a sequência alvo, promove a neutralização da carga significativa. 


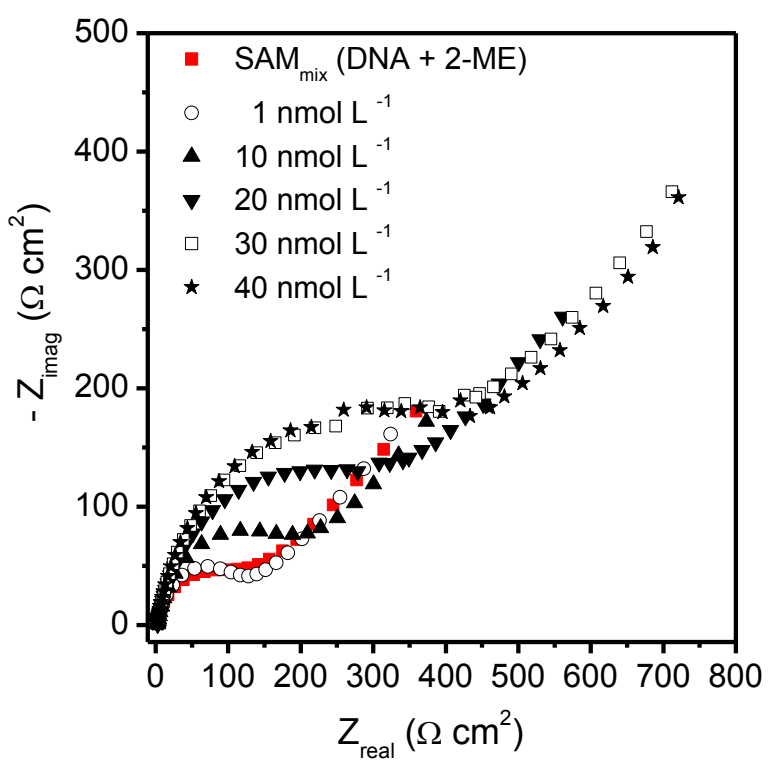

Figura 30 - Diagrama de Nyquist representando as impedâncias complexas para diferentes concentrações de sequência alvo $\left(1,10,20,30 \mathrm{e} 40 \mathrm{nmol} \mathrm{L}^{-1}\right)$ após a primeira hibridização nos eletrodos modificados com $\mathrm{SAM}_{\text {mix }}$ (DNA captura + 2-ME). A linha em vermelho representa a impedância dessa modificação. As análises foram realizadas em tampão PBS, $\mathrm{pH}=7,4$ contendo $5 \mathrm{mM}\left[\mathrm{Fe}(\mathrm{CN})_{6}\right]^{3-4-4}$.

Uma vantagem particular da utilização do AuNP-PAMAM G4/Oligonucleotídeo foi demonstrado na impedância da segunda hibridização. Comparando os resultados para o ensaio com e sem o conjugado, observou-se que o valor máximo da impedância real, $Z_{\text {real, }}$ Figura 29b, foi de $298 \Omega$. O processo de transferência de carga e a resistência foram significativamente reduzidos em comparação com o mesmo processo para o eletrodo normal sem o conjugado, em que foi observado uma resistência de transferência de carga de $576 \Omega$. Posteriormente, foi realizada uma análise de diferentes concentrações do conjugado, para investigar a partir de qual concentração (de AuNP-PAMAM G4) é alcançada a propriedade de facilitar a transferência de cargas no genossensor. Esses resultados são mostrados na Figura 31 em diagrama de Nyquist para concentrações entre $0,22 \mathrm{nmol} \mathrm{L}^{-1}$ e $2,21 \mathrm{nmol} \mathrm{L}^{-1}$ da AuNP-PAMAM G4 presentes nos AuNP-PAMAM G4/Oligonucleotídeo utilizados na segunda hibridização. 


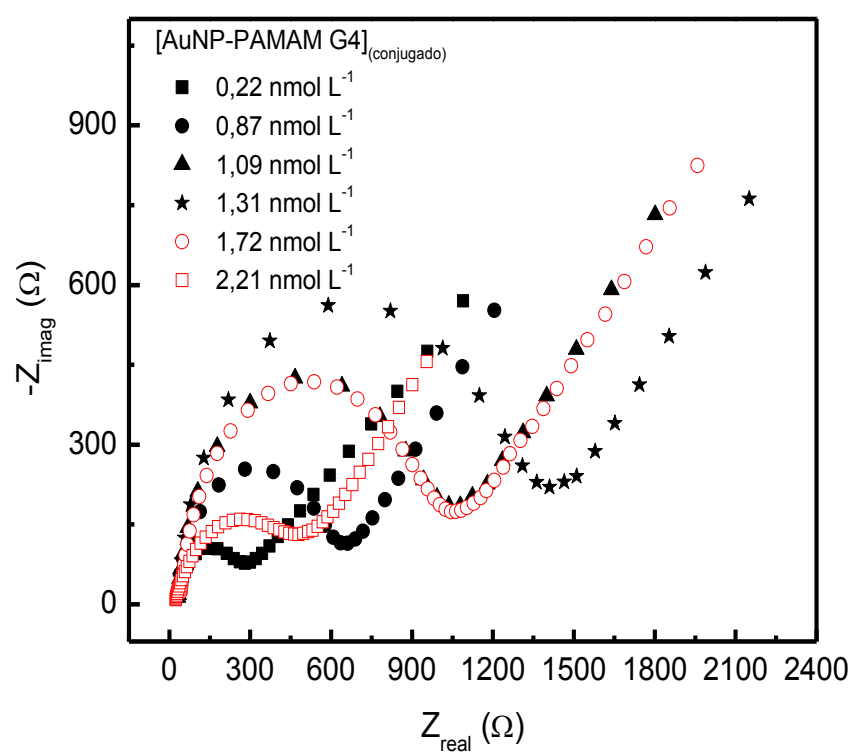

Figura 31 - Diagrama de Nyquist representando as impedâncias complexas para diferentes concentrações de AuNP-PAMAM G4 presente nos AuNP-PAMAM G4/Oligonucleotídeo após hibridização com sequência alvo ancorada $\left(0,26 \mathrm{nmol} \mathrm{L}^{-1}\right)$ no eletrodo modificado com $\mathrm{SAM}_{\text {mix }}$ (DNA + 2-ME). As análises foram realizadas em tampão $\mathrm{PBS}, \mathrm{pH}=7,4$ contendo $5 \mathrm{mM}\left[\mathrm{Fe}(\mathrm{CN})_{6}\right]^{3-/ 4-}$.

Como mostrado na Figura 31, o genossensor com o conjugado exibiu dois comportamentos diferentes. No intervalo de concentração baixa, de $0,22 \mathrm{nmol} \mathrm{L}{ }^{-1}$ a 1,31 nmol $\mathrm{L}^{-1}$, a resistência da transferência de elétrons aumentou. Isso era esperado porque a concentração AuNP-PAMAM G4 é baixa, o que significa que as AuNPs nessa faixa de concentração não influenciam na resistência de transferência de cargas do sistema. Com a aplicação de uma concentração mais elevada (superior a 1,72 $\mathrm{nmol} \mathrm{L}^{-1}$ ) de AuNP-PAMAM G4 no genossensor, resultou em um aumento na transferência de elétrons (menor $R_{c t}$ ), o que significa menos inibição das espécies redox e uma elevada sensibilidade.

Com o intuito de confirmar a presença de sequências de DNA imobilizadas nos eletrodos, confirmando os resultados e para analisar a organização molecular, a microscopia confocal de fluorescência foi realizada.

\subsubsection{Microscopia Confocal de Fluorescência}

A microscopia confocal de fluorescência foi realizada em cada etapa de construção do genossensor (Figura 28). Cada etapa foi realizada em um eletrodo. Os eletrodos foram 
submetidos a um banho de brometo de etídio, conforme descrito no tópico 4.5.7. As imagens de cada etapa estão apresentadas na Figura 32. Como é possível visualizar, existe a presença de DNA nos eletrodos. Além disso, em cada etapa ocorre um aumento na fluorescência, indicando um aumento na quantidade de moléculas de DNA. A maior intensidade de fluorescência ocorre na última etapa, na qual o modelo de hibridização sanduíche já está concluído pela hibridização do AuNP-PAMAM G4/Oligonucleotídeo.
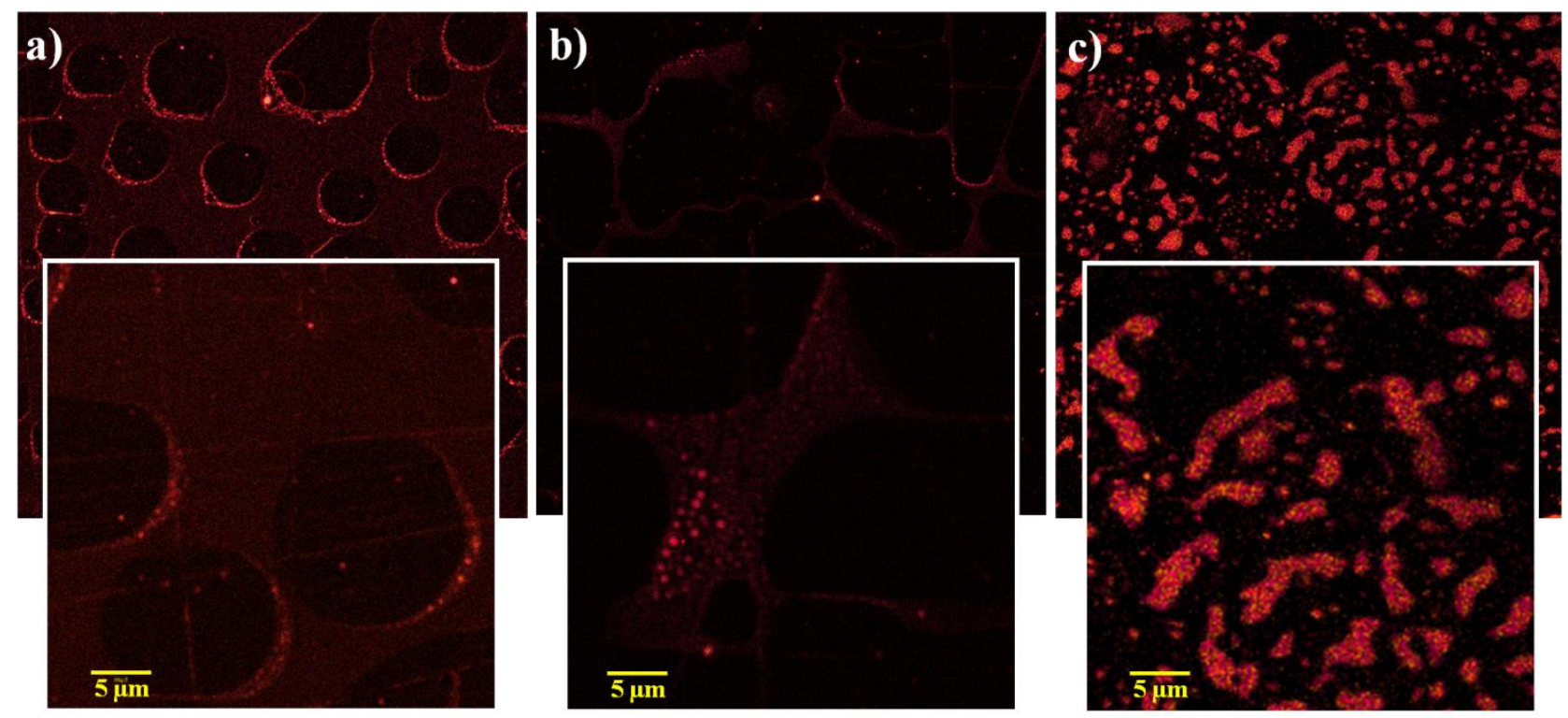

Figura 32 - Imagens de microcopia confocal de fluorescência das etapas de construção e detecção do genossensor: a) Imobilização por meio de $\mathrm{SAM}_{\text {mix }}$ (sequência de captura + 2-ME), b) Primeira hibridização com a sequência alvo e c) Segunda hibridização com o AuNP-PAMAM G4/Oligonucleotídeo. Posteriormente cada etapa os eletrodos foram submetidos a um banho em uma solução $0,1 \mu \mathrm{g} \mathrm{mL}^{-1}$ de brometo de etídio e lavados em água ultrapura abundantemente. Escala em amarelo $(5 \mu \mathrm{m})$.

Foram obtidas imagens de microscopia confocal de fluorescência em 3D, que estão mostradas na Figura 33. Algumas diferenças estruturais interessantes foram observadas. A sequência alvo é detectada por hibridização em modelo sanduíche com a sequência de captura e a sequência presente no conjugado (AuNP-PAMAM G4/Oligonucleotídeo). O processo de hibridização ocorreu em duas etapas. Na Figura 33a é observado a imagem de fluorescência após a primeira etapa com a hibridização da sequência alvo, e nessa imagem é possível ver que as moléculas de DNA estão bem distribuídas, e que ocorreu a primeira hibridização. Além disso, a sequência imobilizada após a hibridização exibe um formato de "pilares" (Figura 33a) com a base bem definida. Esse formato é devido a maior intensidade de 
fluorescência emitida pela dupla fita de DNA formada na base do genossensor conforme o esperado (Figura 28). A eficácia do sistema é mostrada na Figura 33b, após a segunda hibridização com o conjugado específico para a região do polimorfismo estudado. Após a hibridização, o sistema adquiriu um formato de "pinos de boliche" (Figura 33b) correspondente ao formato de sanduíche empregado. Além disso, é possível observar uma descontinuidade e a redução da emissão na região central das fitas, esse fato pode ser atribuído a conformação do DNA, que se encontra em simples fita nessa região. Com isso, a emissão do brometo de etídio é na faixa de 20 vezes menor, quando comparada a emissão da conformação de dupla fita.

A distribuição das sequências de DNA foi homogênea com uma boa organização e orientação das moléculas sobre a superfície do eletrodo, confirmando a proposta de moléculas de DNA distribuídas sobre a superfície do eletrodo em torno das moléculas de 2-ME, formando um sistema de organização com ilhas de material ${ }^{83}$. Este padrão faz com que o genossensor seja mais sensível, e apresente um comportamento bem definido na resistência de transferência de carga.
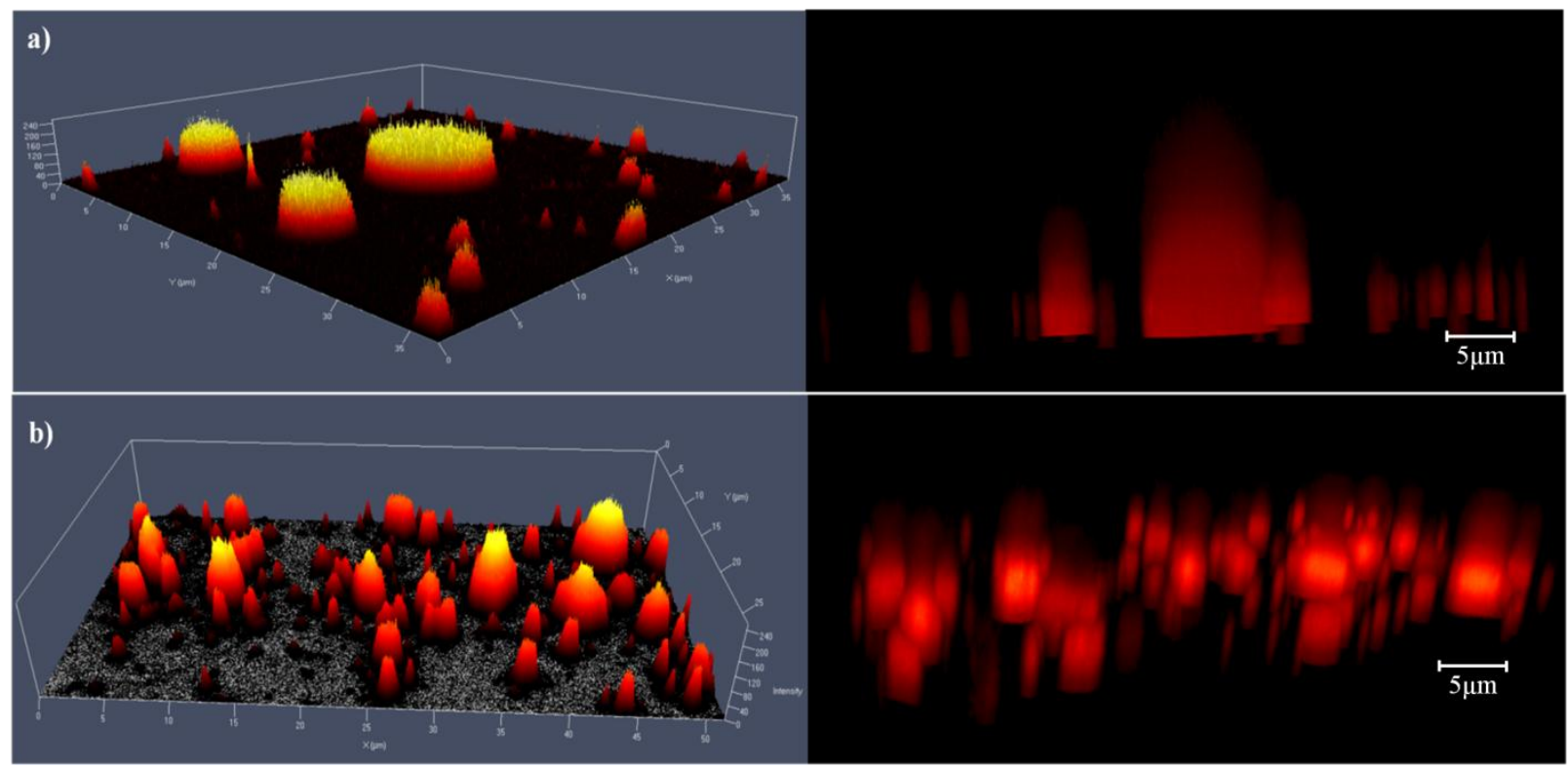

Figura 33 - Microscopia confocal de fluorescência em 3D. Todos os eletrodos de ouro foram submetidos ao banho de brometo de etídio posterior a modificação com um SAM $_{\text {mix }}$ contendo sequências de captura e de 2-mercaptoetanol (2-ME). a) imagem obtida após a primeira hibridização com sequência alvo e b) após a segunda hibridização com o AuNP-PAMAM G4/Oligonucleotídeo. 
5.4 Desenvolvimento e caracterização do genossensor sem a utilização do AuNPPAMAM G4/Oligonucleotídeo

\subsubsection{Detecção em Transistor de Efeito de Campo de Porta Estendida e Separada (SEGFET)}

A técnica de SEGFET vem sendo muito utilizada na detecção de sequências complementares em dispositivos genéticos ${ }^{125}$. A Figura 34 mostra como varia $I_{D}$ ao longo do tempo antes e depois da imersão do eletrodo de Au modificado com SAM mix $_{\text {(sequência de }}$

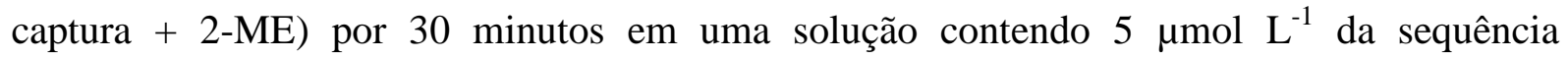
complementar de DNA 5'GGCGAAACCACATAAAAGTGACTGT 3'. Ocorre um decaimento do valor de $\mathrm{I}_{\mathrm{DS}}$ (aproximadamente 4,40 $\mu \mathrm{A}$ ) em virtude do aumento das cargas negativas após a hibridização ${ }^{126}$. Ou seja, com ao aumento das cargas negativas, ocorre uma repulsão de elétrons no canal do transistor e consequentemente, uma diminuição de $\mathrm{I}_{\mathrm{DS}}$.

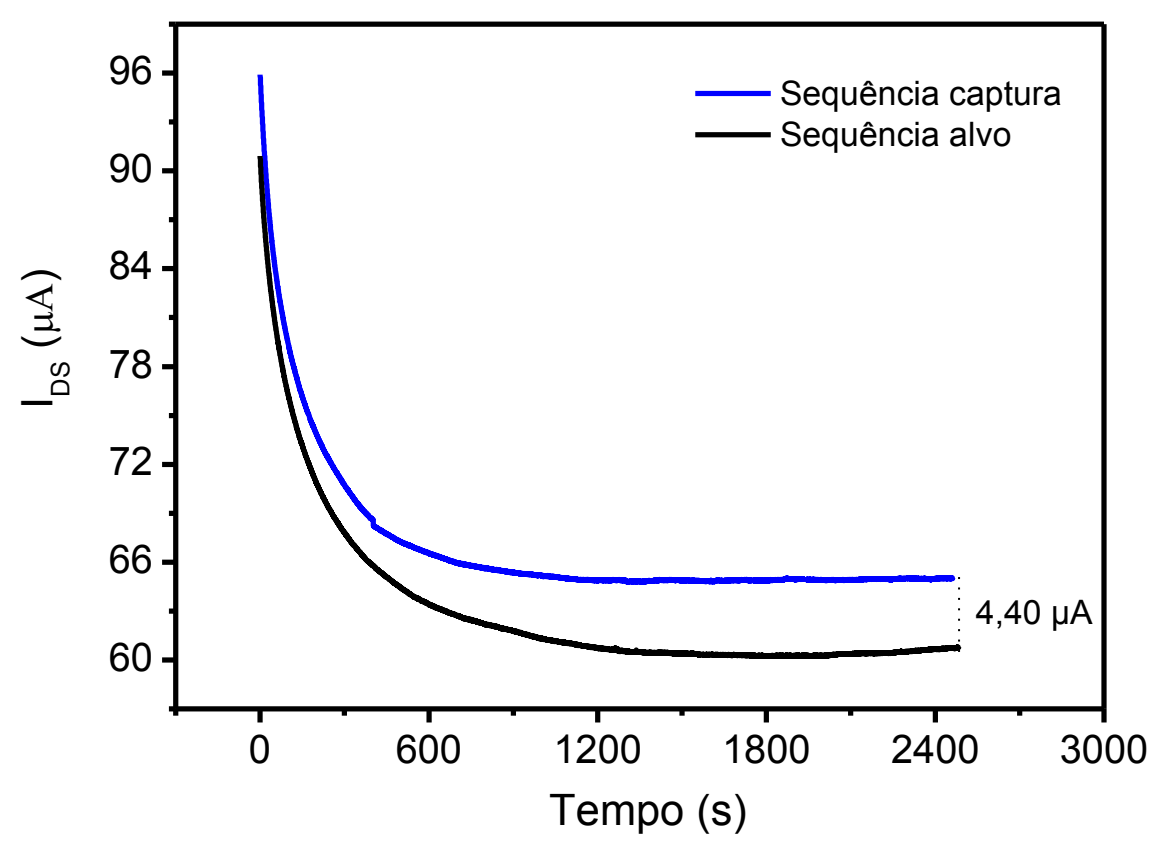

Figura 34 - Curva de $\mathrm{I}_{\mathrm{DS}}$ tomada ao longo do tempo com sequência de captura $\left(\mathrm{SAM}_{\text {mix }}\right)$ e depois de hibridizar com a sequência alvo.

Outra maneira de caracterizar o processo de hibridização é por meio da medida das curvas I x V características de um MOSFET antes e após ocorrer o processo de hibridização. 
As Figuras 35 e 36 mostram como variam as curvas $\mathrm{I} x \mathrm{~V}\left(\mathrm{I}_{\mathrm{DS}} \times \mathrm{V}_{\mathrm{DS}}\right.$, Figura 35 e $\mathrm{I}_{\mathrm{DS}} \mathrm{x} \mathrm{V}_{\mathrm{GS}}$ Figura 36) antes e depois a imersão do eletrodo modificado na solução contendo $5 \mu \mathrm{mol} \mathrm{L}^{-1}$ de sequência complementar. O mesmo decaimento da corrente $(\sim 4,4 \mu \mathrm{A})$ é observado na Figura 36, corroborando os resultados da medida dinâmica. Entretanto, em termos de $\mathrm{V}_{\mathrm{GS}}$, Figura 36, ocorre um deslocamento da curva no sentido positivo de tensão, indicando uma tendência ao aumento da voltagem de limiar do transistor. Em outras palavras, o aumento da carga negativa após a hibridização tende a aumentar o valor da tensão mínima necessária para que o transistor comece a operar.

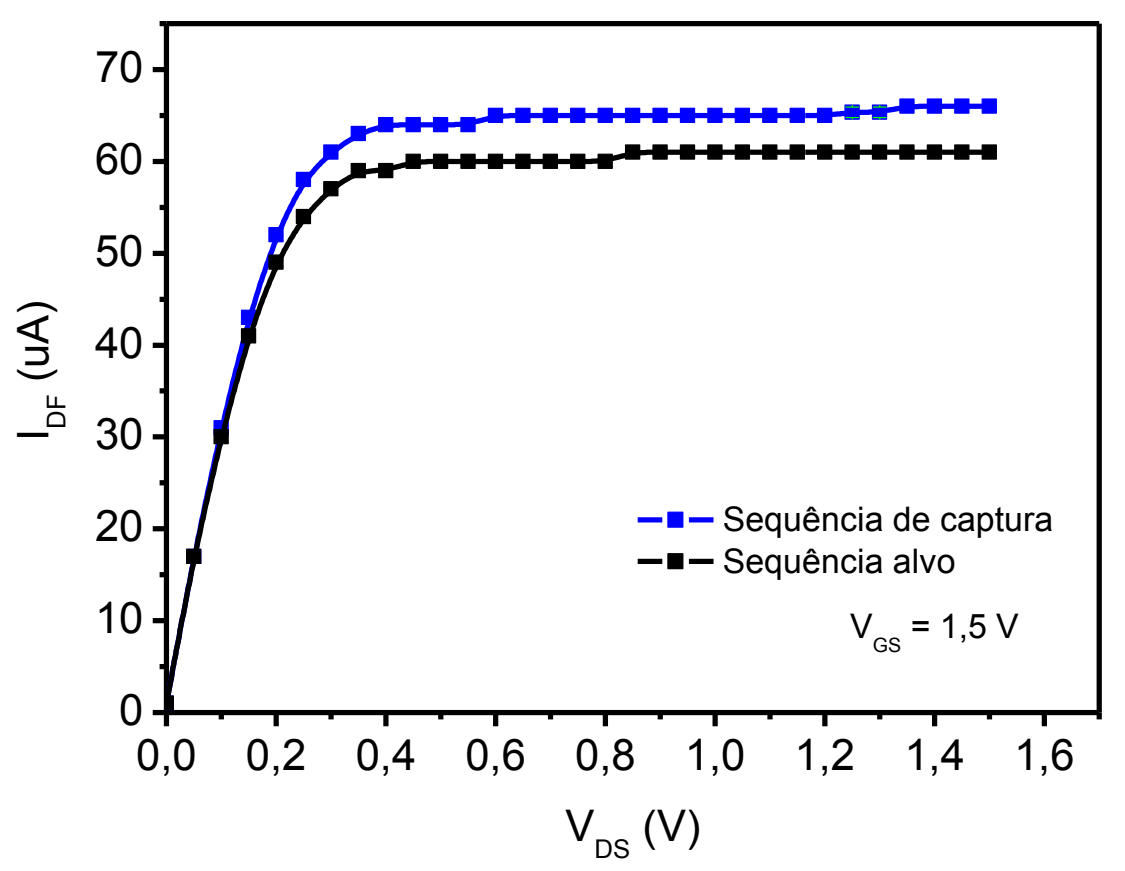

Figura 35 - Curvas características $\mathrm{I}_{\mathrm{DS}} \mathrm{x} \mathrm{V}_{\mathrm{DS}}$ do dispositivo SEGFET tomada da sequência de captura e depois da hibridização com a sequência alvo. 


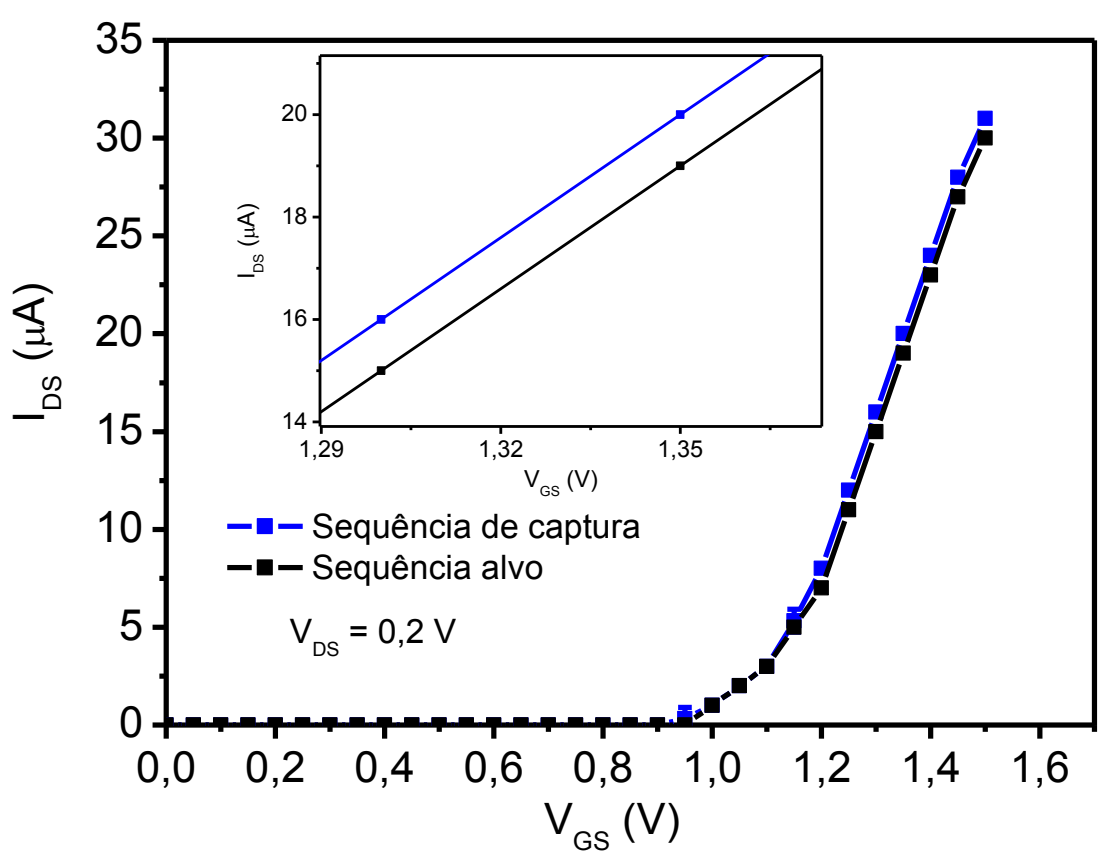

Figura 36 - Curvas características $I_{D S} \times V_{G S}$ para um pequeno valor de $V_{D S}\left(V_{D S}=0,2 V\right)$ do dispositivo SEGFET tomada da sequência de captura e depois da hibridização com a sequência alvo. O Inset com zoom na região de 14 a $21 \mu \mathrm{A}$ da corrente $\mathrm{I}_{\mathrm{DS}}$.

Apesar dos bons resultados do genossensor com a imobilização $\mathrm{SAM}_{\text {mix }}$, passamos a observar no decorrer dos experimentos que quando se usa uma sequência de DNA não complementar, existe um sinal falso-positivo (resultado não mostrado), o que é indesejado em sensores para aplicações clínicas. Esse resultado inesperado pode estar associado a alguma reação entre o tiol imobilizado e a sequência não complementar, levando a um sinal elevado da sequência negativa. Por isso, os mesmos experimentos anteriores foram repetidos para a imobilização direta do DNA alvo no eletrodo de ouro sem a presença de tiol.

A Figura 37 mostra como varia $I_{D}$ ao longo da construção do genossensor: (1) sequência imobilizada de captura $+5 \mu \mathrm{mol} \mathrm{L}^{-1}$ de tampão TE $1 \mathrm{X}$, (2) solução contendo 5 $\mu$ mol L $L^{-1}$ da sequência de DNA não complementar e (3) Finalmente em uma solução contendo $5 \mu$ mol $\mathrm{L}^{-1}$ da sequencia complementar de DNA 5', GGCGAAACCACATAAAAGTGACTGT 3'. Observa-se pela Figura 37a que não ocorre mudança significativa na corrente durante as etapas 1 e 2 . Por outro lado, na etapa 3 (hibridização), ocorre um decaimento de aproximadamente 2,60 $\mu \mathrm{A}$. Apesar do sinal menor em comparação com o sistema de imobilização utilizando $\mathrm{SAM}_{\text {mix }}$ o sistema não apresenta um sinal significativo para a sequência negativa. Dessa forma, podemos concluir que de fato pode ocorrer algum rearranjo de carga quando se utiliza tiol na imobilização. Os mesmos 
resultados foram obtidos em termos das características I x V e são mostrados nas Figuras 37b e 37c. Ou seja, uma diminuição do valor da corrente na curva $I_{D S} x V_{D S}$, e um deslocamento da tensão no sentido positivo na curva $\mathrm{I}_{\mathrm{DS}} \mathrm{x} \mathrm{V}_{\mathrm{GS}}$.
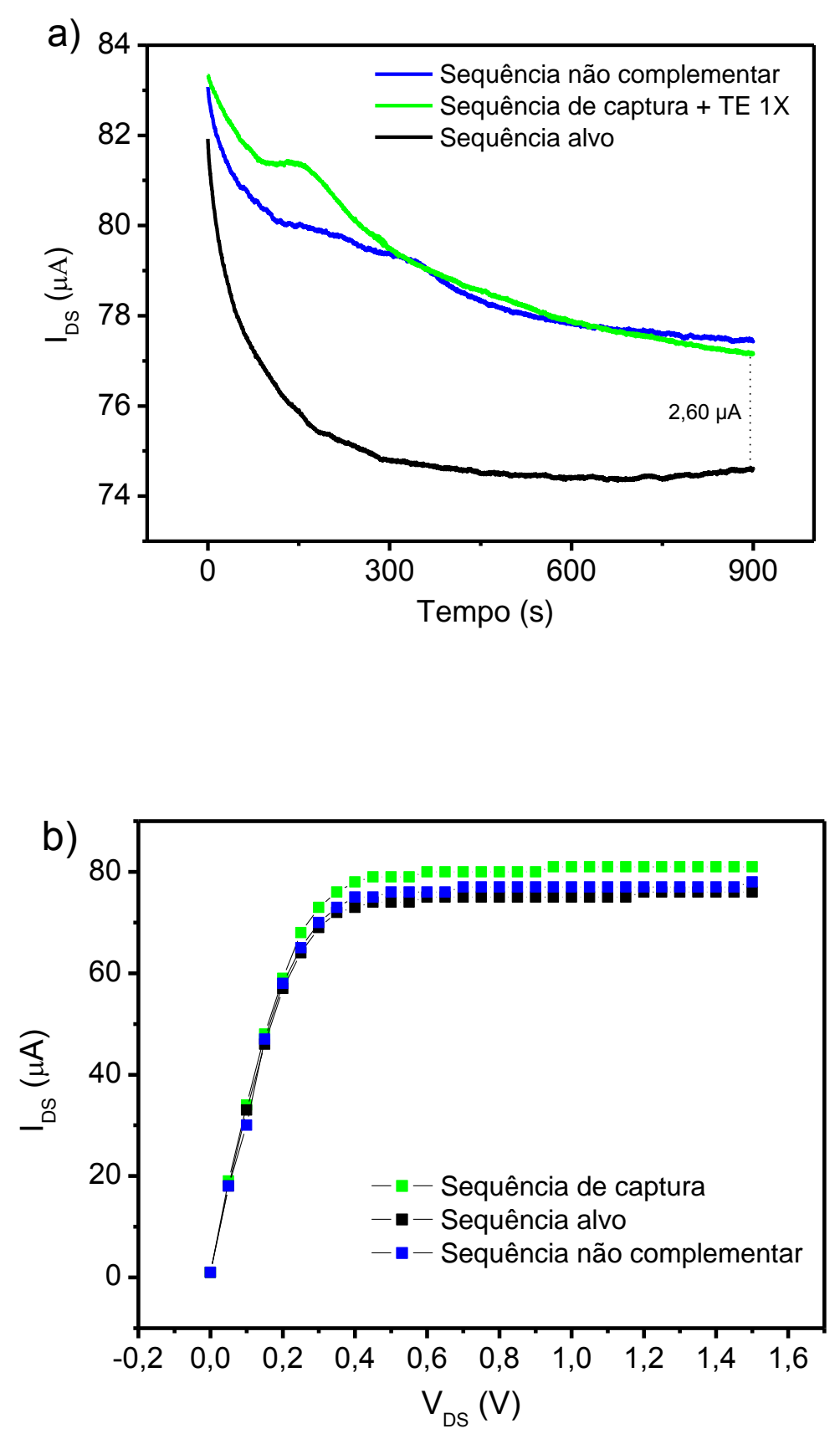
continuação

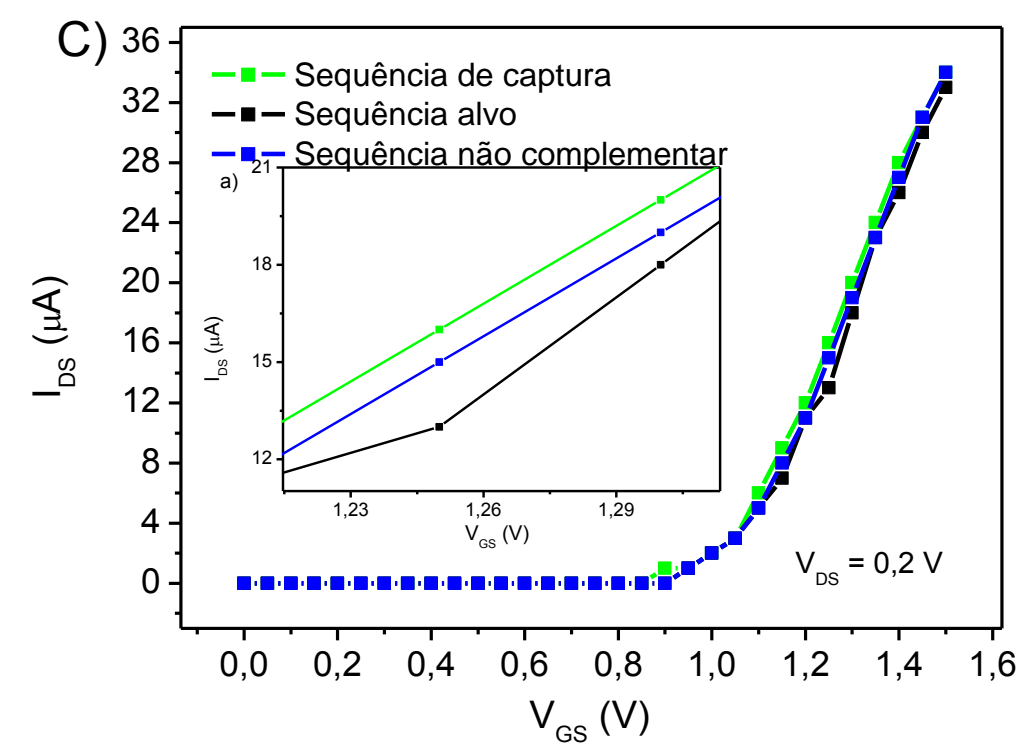

Figura 37- a) Curva de $I_{D S}$ tomada ao longo do tempo com a sequência de captura, sequência não complementar e depois da hibridização com a sequência alvo, b) Curvas características $I_{D S} \times V_{D S}$ do dispositivo SEGFET tomada da sequência de captura, sequência não complementar e depois da hibridização com a sequência alvo e c) Curvas características $I_{D S} \times V_{G S}$ para um pequeno valor de $V_{D S}\left(V_{D S}=0,2\right.$ V) tomada da sequência de captura, sequência não complementar e depois da hibridização com a sequência alvo. O Inset (c) com zoom na região de 11 a $21 \mu \mathrm{A}$ da corrente $\mathrm{I}_{\mathrm{DS}}$.

Nesse sistema a detecção da deleção (fragmento Alu = 287 pb), que caracteriza uma predisposição à hipertensão arterial foi obtida de forma direta utilizando o sensor SEGFET. Esse sistema apresentou reprodutividade e especificidade, além de um ótimo perfil nas etapas de detecção. 


\section{CONCLUSÕES}

Os resultados desse trabalho mostram a importância de estudos com conjugados envolvendo nanomateriais e biomoléculas, uma vez que suas propriedades associadas às questões médicas podem criar novos métodos potencialmente eficientes, tanto no diagnóstico como na terapêutica. Nesse caso, esses materiais foram empregados para o desenvolvimento de um novo sistema de detecção da deleção do polimorfismo de inserção e deleção do gene da ECA com potencialidade para diagnóstico avançado de predisposição à hipertensão arterial sistêmica.

$\mathrm{Na}$ etapa de síntese e caracterização do conjugado AuNP-PAMAM G4/Oligonucleotídeo concluímos por meio das técnicas de TEM, UV-VIS e DLS que a rota de síntese empregada, tanto para as nanopartículas de ouro, quanto para a conjugação com o oligonucleotídeo foi eficiente. A conjugação das nanopartículas de ouro com a sequência de DNA foi alcançada com sucesso. Essa conjugação ocorreu por meio de interações covalentes entre os compostos, confirmadas pela espectroscopia no infravermelho (FTIR). Além disso, por meio das técnicas de caracterização como potencial zeta, PCR em tempo real e UV-VIS, observou-se que esse conjugado apresentou estabilidade e a sequência de DNA conjugada permaneceu funcional, podendo o mesmo ser utilizado na construção de sistemas de detecção.

Foram analisados três sistemas de detecção, com arquiteturas e metodologias diferentes: genossensor elétrico em modelo de hibridização sanduíche, genossensor eletroquímico com $\mathrm{SAM}_{\text {mix }}$ em modelo de hibridização sanduíche e genossensor em modelo de hibridização direta. No primeiro sistema, os eventos de detecção elétrica do genossensor, realizados por espectroscopia de impedância elétrica, se mostram específicos para a sequência complementar, não hibridizando com sequências não complementares. Além disso, o conjugado AuNP-PAMAM G4/Oligonucleotídeo amplificou o sinal diminuindo a resistência de transferência de cargas, tornando o sistema menos resistivo.

No segundo sistema, os eventos de detecção foram realizados por espectroscopia de impedância eletroquímica, a $\mathrm{SAM}_{\text {mix }}$ empregada na imobilização da sequência de captura se mostrou uma estratégia eficiente para a organização e orientação molecular, permitindo que as sequências de DNA fossem ancoradas em torno da molécula de 2-ME. Esses resultados foram evidenciados pelas imagens de microscopia confocal de fluorescência. Nas análises de detecção utilizando a espectroscopia de impedância eletroquímica o genossensor teve o 
mesmo comportamento que o primeiro sistema (elétrico), durante as etapas de detecção do conjugado, diminuindo a resistência de transferência de cargas indicando a ocorrência na hibridização.

No terceiro sistema (com detecção SEGFET), não foi empregado o conjugado, e, portanto, o modelo utilizado foi de hibridização direta. Este sistema também foi eficiente para detectar a sequência complementar ocorrendo um decaimento do valor de $\mathrm{I}_{\mathrm{DS}}$ em virtude do aumento das cargas negativas do grupo fosfato, após a hibridização. Esse fenômeno foi observado tanto no sistema com $\mathrm{SAM}_{\text {mix }}$, quanto na imobilização direta da sequência de captura, com ótima reprodutibilidade. No entanto, não pode ser comparado com os outros dois sistemas em que houve a utilização do conjugado AuNP-PAMAM G4/Oligonucleotídeo.

Pelo exposto, todas as etapas propostas nesse trabalho foram realizadas e os resultados evidenciam o potencial de aplicabilidade, tanto do conjugado AuNP-PAMAM G4/Oligonucleotídeo, quanto dos sistemas de detecção que podem ser utilizados como novas plataformas de diagnósticos biomoleculares. Os genossensores apresentados nesse trabalho foram construídos e otimizados para o polimorfismo de inserção e deleção do gene da ECA, associado à predisposição à hipertensão arterial. No entanto, podem ser empregados para qualquer patologia que apresente uma carga genética e/ou uma sequência estabelecida. 


\section{PERSPECTIVAS}

Os conjugado AuNP-PAMAM G4/Oligonucleotídeo e as plataformas de detecções do genossensor podem ser analisadas por microscopia de força atômica (AFM) e por espectroscopia Ramam, para um estudo mais detalhado do arranjo superficial desses sistemas.

Os genossensores devem ser testados com os mesmos sistemas de detecção diretamente em DNA genômico, mediante aprovação do comitê de ética em pesquisa envolvendo seres humanos. O pedido ao comitê de ética já foi solicitado e está em andamento. As análises em DNA genômico deverão ser realizadas após o tratamento de extração, no entanto, sem a amplificação do gene, excluindo a etapa de amplificação por PCR. Dessa forma, esperamos otimizar a utilização do genossensor, e, assim, aumentar o seu caráter social e econômico. Após essas etapas o genossensor poderá ser proposto comercialmente. 


\section{REFERÊNCIAS}

1 KUMAR, C. S. S. R. Biofunctionalization of nanomaterials: biofuncionalization of gold nanoparticles. Weinheim: Wiley-VCH, 2005. p. 99.

2 DYKMAN, L.; KHLEBTSOV, N. Gold nanoparticles in biomedical applications: recent advances and perspectives. Chemical Society reviews, v. 41, n. 6, p. 2256-2282, 2012.

$3 \mathrm{CHOI}$, J.-W. Nanotechnology in biodevices. Journal of Microbiology and Biotechnology, v. 17, n. 1, p. 5-17, 2007.

4 KOHLES, S. S. A multivariate logistical model for identifying the compressive sensitivity of single rat tactile receptors as nanobiosensors. Journal of Nanotechnology in Engineering and Medicine, v. 2, n. 1, 2011. DOI: $10.1115 / 1.4002750$

5 WANG, X. et al. Engineering nanomaterial surfaces for biomedical applications. Experimental Biology and Medicine, v. 234, n. 1, p. 1128-1139, 2009.

6 PERIASAMY, A. P.; UMASANKAR, Y.; CHEN, S.-M. Nanomaterials-acetylcholinesterase enzyme matrices for organophosphorus pesticides electrochemical sensors: a review. Sensors, v. 9, n. 1, p. 4043-4055, 2009.

7 STRADIOTTO, N. R.; YAMANAKA, H.; ZANONI, M. V. B. Eletrochemical sensors: a powerfel tool in analytical chemistry. Journal of the Brazilian chemical society, v. 14, n. 4, p. 159-173, 2003.

8 DRUMMOND, T. G.; HILL, M. G.; BARTON, J. K. Electrochemical DNA sensors. Nature biotechnology, v. 21, n. 10, p. 1192-1199, 2003.

9 BONANNI, A.; DEL VALLE, M. Use of nanomaterials for impedimetric DNA sensors: a review. Analytica Chimica Acta, v. 678, n. 1, p. 7-17, 2010.

10 DHA - Departamento de Hipertensão Arterial. V Diretrizes Brasileiras de Hipertensão Arterial. 2006. Disponível em: <http://departamentos.cardiol.br/dha/vdiretriz/vdiretriz.asp>. Acesso em: 20 dez. 2011.

11 STRELEC, M. A. M.; PIERIN, A. M. G.; MION, D. J. A influência do conhecimento sobre a doença e a atitude frente à tomada dos remédios no controle da hipertensão arterial. Arquivos Brasileiros de Cardiologia, v. 81, n. 4, p. 343-348, 2003. 
12 BRASIL. Ministério da Saúde. DATASUS - Departamento de Informática do SUS. Disponível em: <http://www.datasus.gov.br >. Acesso em: 04 jan. 2012.

13 RIGAT, B.; HUBERT, C.; ALHENC-GELAS, F.; CAMBIEN, F.; CORVOL, P.; SOUBRIER, F. An Insertion/Deletion Polymorphism in the Angiotensin I-converting Enzyme Gene Accounting for Half the Variance of Serum Enzyme Levels. Journal of Clinical Investigation, v. 86, n. 4, p. $1343-1346$, 1990.

14 MEDEIROS, E. S.; MATTOSO, L. H. C. Aplicações da nanotecnologia no agronegócio: nanotecnologia - introdução, preparação e caracterização de nanomateriais e exemplos de aplicação. São Paulo: Artliber, 2006. p. 16-18.

15 DREXLER, K. E. Molecular engineering: An approach to the development of general capabilities for molecular manipulation. Proceedings of the National Academy of Sciences, v. 78, n. 9, p. 5275-5278, 1981.

16 POTOČNIK, J. Recomendações da comissão européia: sobre a definição de nanomaterial. Jornal Oficial da União Europeia, v. 275, n. 292, p. 38-40, 2011.

17 NEL, A.; XIA, T.; MADLER, L.; LI, N. Toxic potential of materials at the nanolevel. Science, v. 311, n. 5761, p. 622-627, 2006.

18 XIN-RUI XIA; MONTEIRO-RIVIERE, N. A.; RIVIERE, J. E. An index for characterization of nanomaterials in biological systems. Nature Nanotechnology, v. 5, p. 671-675, 2010. DOI:10.1038/nnano.2010.164.

19 DUAN, C.-F.; YU, Y.-Q.; CUI, H. Gold nanoparticle-based immunoassay by using non-stripping chemiluminescence detection. Analyst, v. 133, n. 9, p. 1250-1255, 2008.

20 HUANG, H.; DELIKANLI, S.; ZENG, H.; FERKEY, D. M.; PRALLE, A. Remote control of ion channels and neurons through magnetic-field heating of nanoparticles. Nature Nanotechnology, v. 5, n. 1, p. 602-606, 2010.

21 FDA - U.S. Food and Drug Administration. Disponível em: <http://www.fda.gov/>. Acesso em: 10 Nov. 2011.

22 JAMES, F. H.; DANIEL, N. S.; HENRY, M. S. The use of gold nanoparticles to enhance radiotherapy in mice. Physics in Medicine and Biology, v. 49, n. 18, p. N309, 2004.

23 HAZARIKA, P.; CEYHAN, B.; NIEMEYER, C. M. Reversible Switching of DNA-Gold Nanoparticle Aggregation. Angewandte Chemie International Edition, v. 43, n. 47, p. 6469-6471, 2004. 
24 WALKEY, C.; SYKES, E. A.; CHAN, W. C. W. Application of Semiconductor and Metal Nanostructures in Biology and Medicine. Hematology, v. 2009, n. 1, p. 701-707, 2009.

25 MEDINA, C.; SANTOS-MARTINEZ, M. J.; RADOMSKI, A.; CORRIGAN, O. I.; RADOMSKI, M. W. Nanoparticles: pharmacological and toxicological significance. British Journal of Pharmacology, $v$. 150, n. 5, p. 552-558, 2007.

26 KENNEDY, L. C.; BICKFORD, L. R.; LEWINSKI, N. A.; COUGHLIN, A. J.; HU, Y.; DAY, E. S.; WEST, J. L.; DREZEK, R. A. A new era for cancer treatment: gold-nanoparticle-mediated thermal therapies. Small, v. 7, n. 2, p. 169-183, 2011.

27 GHANN, W. E.; ARAS, O.; FLEITER, T.; DANIEL, M.-C. Syntheses and characterization of lisinoprilcoated gold nanoparticles as highly stable targeted ct contrast agents in cardiovascular diseases. Langmuir, v. 28, n. 28, p. 10398-10408, 2012.

28 SOO, P.-C.; HORNG, Y.-T.; CHANG, K.-C.; WANG, J.-Y.; HSUEH, P.-R.; CHUANG, C.-Y.; LU, C.-C.; LAI, H.-C. A simple gold nanoparticle probes assay for identification of Mycobacterium tuberculosis and Mycobacterium tuberculosis complex from clinical specimens. Molecular and Cellular Probes, v. 23, n. 5, p. 240-246, 2009.

29 CORCUERA, J. I. R. D.; CAVALIERI, R. P. Biosensors. Encyclopedia of Agricultural, Food, and Biological Engineering, v. 270, n. 1, p. 119-123, 2003.

30 MELLO, L. D.; KUBOTA, L. T. Biosensors as a tool for the antioxidant status evaluation. Talanta, v. 72, n. 2, p. 335-348, 2007.

31 EMBRAPA. Aplicações de biossensores na análise da qualidade de alimentos. 2008. Disponível em: < http://www.cnpat.embrapa.br/cnpat/cd/jss/acervo/Dc 117.pdf>. Acesso em: 23 jan. 2013.

32 THEVENOT, D. R.; TOTH, K.; DURST, R. A.; WILSON, G. S. Electrochemical biosensors: recommended definitions and classification. Biosens. Bioelectron, v. 16, n. 1-2, p. 121-131, 2001.

33 M.GABIG-CIMINSKA; AL, E. Identification of Pathogenic Microbial Cells and Spores by Electrochemical Detection on a Biochip. Microbial Cell Factories, v. 3, n. 2, p. 1-11, 2004.

34 MEHRVAR, M.; AL, E. Fiber-optic biosensors - trends and advances. Analytical Sciences, v. 16, n. 1, p. 677-692, 2000.

35 GAUA, V.; AL., E. Electrochemical Molecular Analysis without Nucleic Acid Amplification. Methods, v. 37, n. 1, p. 73-83, 2005. 
36 WANG, Y.; AL, E. Electrochemical Sensors for Clinic Analysis. Sensors, v. 8, n. 1, p. 2043-2081, 2008.

37 THÉVENOT, D. R.; AL, E. Electrochemical Biosensors: Recommended Definitions and Classification. Biosensors \& Bioelectronics, v. 16, n. 1, p. 121-131, 2001.

38 MELO, A. F. Desenvolvimento Preliminar de um Biossensor Enzimático para Determinação de Taninos Hidrolisáveis. 2008. 104f. Dissertação Mestrado em Ciências - Universidade Federal do Rio de Janeiro. Rio de Janeiro, 2008.

39 WANG, G.; AL, E. A living cell quartz crystal microbalance biosensor for continuous monitoring of cytotoxic responses of macrophages to single-walled carbon nanotubes. Particle and Fibre Toxicology, v. 8, n. 4, p. 1-17, 2011.

40 SASSOLAS, A.; LECA-BOUVIER, B. D.; BLUM, L. J. DNA biosensors and microarrays. Chemical Reviews, v. 108, n. 1, p. 109-139, 2008.

41 BEAUCAGE, S. L. Strategies in the Preparation of DNA Oligonucleotide Arrays for Diagnostic Applications. Current Medicinal Chemistry, v. 8, n. 10, p. 1213-1244, 2001.

42 U.S. NATIONAL LIBRARY OF MEDICINE. National Institutes of Health National. DNA scheme. 1993. Disponível em: <http://www.nlm.nih.gov/>. Acesso em: 23 Jan. 2013.

43 CHATELAIN, G.; RIPERT, M.; FARRE, C. C.; ANSANAY-ALEX, S. A "four-ferrocene" modified stemloop structure as a probe for sensitive detection and single-base mismatch discrimination of DNA. Electrochimica Acta, v. 59, n. 1, p. 57-63, 2012.

44 TICHONIUK, M.; GWIAZDOWSKA, D.; LIGAJ, M.; FILIPIAK, M. Electrochemical detection of foodborne pathogen Aeromonas hydrophila by DNA hybridization biosensor. Biosensors and Bioelectronics, v. 26, n. 1, p. 1618-1623, 2010.

45 BONANNI, A.; ESPLANDIU, M. J.; VALLE, M. Impedimetric genosensing of DNA polymorphism correlated to cystic fibrosis: a comparison among different protocols and electrode surfaces. Biosensors and Bioelectronics, v. 26, n. 1, p. 1245-1251, 2010.

46 FRAGOSOA, A. L. C. A.; HÖLTERSB, S.; DÜRSTB, M.; K., O. S. C. Electrochemical genossensor array for the simultaneous detection of multiple high-risk human papillomavirus sequences in clinical samples. Analytica Chimica Acta, v. 715, n. 1, p. 93-98, 2012.

47 YIMA, S.-C.; PARKA, H. G.; CHANGA, H. N.; CHOB, D.-Y. Array-based mutation detection of BRCA1 using direct probe/target hybridization. Analytical Biochemistry, v. 337, n. 2, p. 332 - 337, 2005. 
48 ENSAFI, A. A.; TAEI, M.; RAHMANI, H. R.; KHAYAMIAN, T. Sensitive DNA impedance biosensor for detection of cancer, chronic lymphocytic leukemia, based on gold nanoparticles/gold modified electrode. Electrochimica Acta, v. 56, n. 24, p. 8176-8183, 2011.

49 LEE, K. B.; PARK, S. J.; MIRKIN, C. A.; SMITH, J. C.; MRKSICH, M. Protein nanoarrays generated by dip-pen nanolithography. Science, v. 295, n. 5560, p. 1702-1705, 2002.

50 ABAD-VALLE, P.; FERNÁNDEZ-ABEDUL, M. T.; COSTA-GARCÍA, A. Genossensor on gold films with enzymatic electrochemical detection of a SARS virus sequence. Biosensors and Bioelectronics, v. 20, n. 11, p. 2251-2260, 2005.

51 SCHONING, M. J.; POGHOSSIAN, A. Bio FEDs (Field-Effect devices): state-of-the-art and new directions. Electroanalysis, v. 18, n. 19-20, p. 1893-1900, 2006.

52 BERGVELD, P. Thirty years of ISFETOLOGY - What happened in the past 30 years and what may happen in the next 30 years. Sensors and Actuators B-chemical, v. 88, n. 1, p. 1-20, 2003.

53 SPELTHAHN, H.; SCHAFFRATH, S.; COPPE, T.; RUFI, F.; SCHÖNING, M. J. Development of an electrolyte-insulator-semiconductor (EIS) based capacitive heavy metal sensor for the detection of Pb2+ and Cd2+ ions. Physica Status Solidi A, v. 207, n. 4, p. 930-934, 2010.

54 SIQUEIRA, J. R.; BÄCKER, M.; POGHOSSIAN, A.; ZUCOLOTTO, V.; OLIVEIRA, O. N.; SCHÖNING, M. J. Associating biosensing properties with the morphological structure of multilayers containing carbon nanotubes on field-effect devices. Physica Status Solidi A, v. 207, n. 4, p. 781-786, 2010.

55 VANDERSPIEGEL, J.; LAUKS, I.; CHAN, P.; BABIC, D. The extended gate chemically sensitive fieldeffect transistor as multi-species microprobe. Sensors and Actuators, v. 4, n. 2, p. 291-298, 1983.

56 FERNANDES, E. G. R.; VIEIRA, N. C. S.; DE QUEIROZ, A. A. A.; GUIMARÃES, F. E. G.; ZUCOLOTTO, V. Immobilization of Poly(propylene imine) dendrimer/nickel phtalocyanine as nanostructured multilayer films to be used as gate membranes for SEGFET ph sensors. Journal of Physical Chemistry C, v. 114, n. 14, p. 6478-6483, 2010.

57 DZYADEVYCH, S. V.; SOLDATKIN, A. P.; EL'SKAYA, A. V.; MARTELET, C.; JAFFREZIC-RENAULT, N. Enzyme biosensors based on ion-selective field-effect transistors. Analytica Chimica Acta, v. 568, n. 1-2, p. 248-258, 2006.

58 SCHONING, M. J.; POGHOSSIAN, A. Recent advances in biologically sensitive field-effect transistors (BioFETs). Analyst, v. 127, n. 9, p. 1137-1151, 2002. 
59 CHI, L. L.; CHOU, J. C.; CHUNG, W. Y.; SUN, T. P.; HSIUNG, S. K. Study on extended gate field effect transistor with tin oxide sensing membrane. Materials Chemistry and Physics, v. 63, n. 1, p. 19-23, 2000.

60 IBGE - INSTITUTO BRASILEIRO DE GEOGRAFIA E ESTATÍSTICA. Censo demográfico 2000. Disponível em: <http://www.ibge.gov.br/home/estatistica/populacao/default censo 2000.shtm>. Acesso em: 04 Jan. 2012.

61 BOING, A. C.; BOING, A. F. Hipertensão arterial sistêmica: o que nos dizem os sistemas brasileiros de cadastramentos e informações em saúde. Revista Brasileira de Hipertensão, v. 14, n. 2, p. 84-88, 2007.

62 BRANDÃO, A. P.; BRANDÃO, A. A.; MAGALHÃES, M. E. C.; POZZAN, R. Epidemiologia da hipertensão arterial Revista da Sociedade de Cardiologia do Estado de Säo Paulo. v. 13, n. 1, p. 7-19, 2003.

63 LOTUFO, P. A. Stroke in Brazil: a neglected disease. Sao Paulo Medical Journal, v. 123, n. 1, p. 1-4, 2005.

64 B., P. C.; JARDIM, V.; GONDIM, M. D. R. P.; MONEGO, E. T.; MOREIRA, H. G.; VITORINO, P. V. D. O.; SOUZA, W. K. S. B.; SCALA, L. C. N. Hipertensão arterial e alguns fatores de risco em uma capital brasileira. Arquivos Brasileiros de Cardiologia, v. 88, n. 4, p. 452-457, 2007.

65 ANABELA GIESTAS, I. P., MARIA HELENA RAMOS Sistema renina-angiotensina-aldosterona e sua modulação farmacológica. Acta Medica Portuguesa, v. 23, n. 4, p. 677-688, 2010.

66 RE, R. N. The clinical implication of tissue renin angiotensin systems. Current Opinion Cardiology, v. 16, n. 6, p. $317-327,2001$.

67 RAD, A. Renin-angiotensin-aldosterone system. 2006. Disponível em: < <http://commons.wikimedia.org/wiki/File:Renin-angiotensin-aldosterone system.png $>$. Acesso em: 05 Jan. 2012.

68 MURPHEY, L. J.; GAINER, J. V.; VAUGHAN, D. E.; BROWN, N. J. Angiotensin-converting enzyme insertion/deletion polymorphism modulates the human in vivo metabolism of bradykinin. Circulation, v. 102, n. 8, p. 829-832, 2000.

69 BURACZYNSKA, M.; KSIAZEK, P.; DROP, A.; ZALUSKA, W.; SPASIEWICZ, D.; KSIAZEK, A. Genetic polymorphisms of the renin-angiotensin system in end-stage renal disease. Nephrology Dialysis Transplantation, v. 21, n. 4, p. 979-983, 2006. 
70 BELLWON, J.; CHLEBUS, K.; SIBERT, J.; WASAG, B.; OCHMAN, K.; GRUCHALA, M.; LIMON, J.; RYNKIEWICZ, A. Diagnosis of arterial hypertension and ECG left ventricular hypertrophy in relation to angiotensin converting enzyme gene I/D polymorphism during 7 years follow up. Journal of Hypertension. v. 22, n., p. S260-S260, 2004.

71 HAJEK, D.; TOMISKA, M.; KRAHULCOVA, E.; DRUCKMULLER, M.; FLORIANOVA, M.; IZAKOVICOVAHOLLA, L.; VACHA, J. I/D ACE gene polymorphism in survival of leukemia patients - hypothesis and pilot study. Medical Hypotheses, v. 61, n. 1, p. 80-85, 2003.

72 CAM, F. S.; GUMUS, B. H.; VAR, A.; BERDELI, A. Association of Angiotensin-Converting Enzyme I/D and eNOS G894T Gene Polymorphisms with Erectile Dysfunction. Türkiye Klinikleri Tıp Bilimleri Dergisi, v. 31, n. 2, p. 432-437, 2011.

73 JIEMA SHANGHAI BIOMEDICAL TECHNOLOGY CO (JIEM-Non-standard) L. Jiang; J. Pan. Reagent kit useful for screening pregnant women at risk of developing high blood pressure, contains specific primer pair for detecting single nucleotide polymorphism in e.g. angiotensin-converting enzyme gene. CN CN102373285-A, 23 Nov. 2011.

74 SHANGHAI ZHUJIAN BIOENGINEERING CO LTD. Z. FENG; Z. ZOU. Kit for detecting individual genetic susceptibility of hypertension, comprises a special primer pair for simultaneously detecting single nucleotide polymorphism locus of angiotensin converting enzyme gene. CN 101608219-A 20 Jun. 2008, 23 Dez. 2009.

75 CBHA - CONSENSO BRASILEIRO DE HIPERTENSÃO ARTERIAL. Hipertensão arterial - diagnóstico e classificação. 2001.2 Disponível em: <http://www.fef.br/biblioteca/arquivos/data/III consenso bras hip arterial.pdf $>$. Acesso em: 22 de Jan 2013.

76 CRESPILHO, F. N.; GHICA, M. E.; ZUCOLOTTO, V.; NART, F. C.; OLIVEIRA, O. N.; BRETT, C. M. A. Electroactive Nanostructured Membranes (ENM): Synthesis and Electrochemical Properties of Redox Mediator-Modified Gold Nanoparticles Using a Dendrimer Layer-by-Layer Approach. Electroanalysis, v. 19, n. 7-8, p. 805-812, 2007.

77 MANNA, A.; IMAE, T.; AOI, K.; OKADA, M.; YOGO, T. Synthesis of dendrimer-passivated noble metal nanoparticles in a polar medium: comparison of size between silver and gold particles. Chemistry of Materials, v. 13, n. 5, p. 1674-1681, 2001.

78 WANG, P.; ZHAO, X.-H.; WANG, Z.-Y.; MENG, M.; LI, X.; NING, Q. Generation 4 polyamidoamine dendrimers is a novel candidate of nano-carrier for gene delivery agents in breast cancer treatment. Cancer letters, v. 298, n. 1, p. 34-49, 2010. 
79 LUDERER, F.; WALSCHUS, U. Immobilisation of DNA on Chips I: Immobilization of oligonucleotides for biochemical sensing by self-assembled monolayers: thiol-organic bonding on gold and silanization on silica surfaces. 1 ed. Berlin Heidelberg: Springer-Verlag, 2005. p. 42-44.

80 CAT - CENTRE ADVANCED TECHNOLOGY. Linkage modifications. 1985. Disponível em: <http://www.ucalgary.ca/dnalab/synthesis/modifications/linkages >. Acesso em: 20 Dez. 2011.

$81 \mathrm{NCBI}$ - NATIONAL CENTER FOR BIOTECHNOLOGY INFORMATION. ACE angiotensin I converting enzyme (peptidyl-dipeptidase A) 1 [ Homo sapiens ]. Disponível em: <http://www.ncbi.nlm.nih.gov/gene/?term=1636>. Acesso em: 3 Jan. 2012.

82 HERNE, T. M.; TARLOV, M. J. Characterization of DNA probes immobilized on gold surfaces. Journal of the American Chemical Society. . v. 119, n. 38, p. 8916-8920, 1997.

83 GEBALA, M.; SCHUHMANN, W. Controlled orientation of DNA in a binary SAM as a key for the successful determination of DNA hybridization by means of electrochemical impedance spectroscopy. Chemphyschem, v. 11, n. 13, p. 2887-2895, 2010.

84 SCHMID, F. X. Biological macromolecules: UV-visible spectrophotometry. Nature Publishing Group, Macmillan Publishers Ltd, v. 1 , n. 1, p. 1-4, 2001.

85 VAN-HOLDE, K. E. S. Principles of physical biochemistry. 2nd ed. Upper Saddle River: Perason Prentice Hall, 2006.

86 BOHREN, N. C. Absortion and scattering of light small particles.3rd ed. New York: John Wiley, 1983. p. 287

87 CANTOR, C. R.; SCHIMMEL, P. R. Biophysical chemistry. 5th ed. New.York: W. H. Freeman and Company, 1980. p. 349-409.

88 SILVEIRA, N. P.; GIACOMELLI, F. C. Espalhamento de luz aplicada à caracterização de polímeros e nanopartículas. Rio Grande do Sul: Editora UFRGS, 2008. p. 20.

89 LIU, Y.; YANG, C.-H.; LI, J. Adhesion and retention of a bacterial phytopathogen erwinia chrysanthemi in biofilm-coated porous media. Environmental Science \& Technology, v. 42, n. 1, p. 159-165, 2008.

90 DOANE, T. L.; CHUANG, C. H.; HILL, R. J.; BURDA, C. Nanoparticle zeta-potentials. Accounts of Chemical Research, v. 45, n. 3, p. 317-326, 2012.

91 LAMPMAN, G. M. et al. Spectroscopy. 4th ed. Belmont, Calif.: Brooks/ Cole, 2010. 
92 MISHRA, A.; TRIPATHY, S. K.; YUN, S.-I. Fungus mediated synthesis of gold nanoparticles and their conjugation with genomic DNA isolated from Escherichia coli and Staphylococcus aureus. Process Biochemistry, v. 47, n. 5, p. 701-711, 2012.

93 KULKARNI, S. K.; ETHIRAJ, A. S.; KHARRAZI, S.; DEOBAGKAR, D. N.; DEOBAGKAR, D. D. Synthesis and spectral properties of DNA capped CdS nanoparticles in aqueous and non-aqueous media. Biosensors and Bioelectronics, v. 21, n. 1, p. 95-102, 2005.

94 HASSANIEN, R.; AL-SAID, S. A. F.; ŠILLER, L.; LITTLE, R.; WRIGHT, N. G.; HOULTON, A.; HORROCKS, B. R. Smooth and conductive DNA-templated $\mathrm{Cu}_{2} \mathrm{O}$ nanowires: growth morphology, spectroscopic and electrical characterization. Nanotechnology, v. 23, n. 7, p. 1-12, 2012.

95 MILANO, G.; MUSUMECI, D.; GAGLIONE, M.; MESSERE, A. An alternative strategy to synthesize PNA and DNA magnetic conjugates forming nanoparticle assembly based on PNA/DNA duplexes. Molecular BioSystems, v. 6, n. 3, p. 553-561, 2010.

96 PLAPIED, L.; VANDERMEULEN, G.; VROMAN, B.; PRÉAT, V.; DES RIEUX, A. Bioadhesive nanoparticles of fungal chitosan for oral DNA delivery. International Journal of Pharmaceutics, $v$. 398, n. 1-2, p. 210-218, 2010.

97 LEE, K.; LEE, H.; LEE, K. W.; PARK, T. G. Optical imaging of intracellular reactive oxygen species for the assessment of the cytotoxicity of nanoparticles. Biomaterials, v. 32, n. 10, p. 2556-2565, 2011.

98 HUANG, X.; TENG, X.; CHEN, D.; TANG, F.; HE, J. The effect of the shape of mesoporous silica nanoparticles on cellular uptake and cell function. Biomaterials, v. 31, n. 3, p. 438-448, 2010.

99 WU, J.; WANG, Y.-S.; YANG, X.-Y.; LIU, Y.-Y.; YANG, J.-R.; YANG, R.; ZHANG, N. Graphene oxide used as a carrier for adriamycin can reverse drug resistance in breast cancer cells. Nanotechnology, v. 23, n. 35, p. 1-9, 2012.

100 LEPECQ, J. B.; PAOLETTI, C. A fluorescent complex between ethidium bromide and nucleic acids physical-chemical characterization. Journal of Molecular Biology, v. 27, n. 1, p. 87, 1967.

101 KATZ, E.; WILLNER, I. Probing biomolecular interactions at conductive and semiconductive surfaces by impedance spectroscopy: routes to impedimetric immunosensors, DNA-sensors, and enzyme biosensors. Electroanalysis, v. 15, n. 11, p. 913-947, 2003.

102 STERN, E.; WAGNER, R.; SIGWORTH, F. J.; BREAKER, R.; FAHMY, T. M.; REED, M. A. Importance of the debye screening length on nanowire field effect transistor sensors. Nano Letters, v. 7, n. 11, p. 3405-3409, 2007.

103 SHI, X.; GANSER, T. R.; SUN, K.; BALOGH, L. P.; JR, J. R. B. Characterization of crystalline dendrimer-stabilized gold nanoparticles. Nanotechnology, v. 17, n. 4, p. 1072, 2006. 
104 HAISS, W.; THANH, N. T. K.; AVEYARD, J.; FERNIG, D. G. Determination of size and concentration of gold nanoparticles from UV-Vis spectra. Analytical Chemistry, v. 79, n. 11, p. 4215-4221, 2007.

105 LIU, X.; ATWATER, M.; WANG, J.; HUO, Q. Extinction coefficient of gold nanoparticles with different sizes and different capping ligands. Colloids and Surfaces B: biointerfaces, v. 58, n. 1, p. 3-7, 2007.

106 PANCHAPAKESAN, B.; BOOK-NEWELL, B.; SETHU, P.; RAO, M.; IRUDAYARAJ, J. Gold nanoprobes for theranostics. Nanomedicine, v. 6, n. 10, p. 1787-1811, Dec 2011.

107 SCHMID, F. X. Biological macromolecules: UV-visible spectrophotometry. 2001. DOI: 10.1038/npg.els.0003142

108 RICH, A.; ZHANG, S. G. Z-DNA: the long road to biological function. Nature Reviews Genetics, v. 4, n. 7, p. 566-572, 2003.

109 DOANE, T. L.; CHUANG, C.-H.; HILL, R. J.; BURDA, C. Nanoparticle zeta-Potentials. Accounts of Chemical Research, v. 45, n. 3, p. 317-326, 2012.

110 COLTHUP, N. B.; DALY, L. H.; WIBERLEY, S. E. Introduction to infrared and Raman spectroscopy. 3rd ed. San Diego: Academic Press, 1990.

111 MADY, M. M.; MOHAMMED, W. A.; EL-GUENDY, N. M.; ELSAYED, A. A. Interaction of DNA and polyethylenimine: Fourier-transform infrared (FTIR) and differential scanning calorimetry (DSC) studies. International Journal of Physical Sciences, v. 6, n. 32, p. 7328-7334, 2011.

112 XIANG, S. D.; BENSON, E. M.; DUNN, I. S. Tracking membrane and secretory immunoglobulin alpha heavy chain mRNA variation during B-cell differentiation by real-time quantitative polymerase chain reaction. Immunology and Cell Biology, v. 79, n. 5, p. 472-481, 2001.

113 ESTALILLA, O. C.; MEDEIROS, L. J.; MANNING, J. T.; LUTHRA, R. 5 '-> 3 ' exonuclease-based realtime PCR assays for detecting the $t(14 ; 18)(q 32 ; 21)$ : a survey of 162 malignant lymphomas and reactive specimens. Modern Pathology, v. 13, n. 6, p. 661-666, 2000.

114 CHEN, P.; PAN, D.; FAN, C.; CHEN, J.; HUANG, K.; WANG, D.; ZHANG, H.; LI, Y.; FENG, G.; LIANG, P.; HE, L.; SHI, Y. Gold nanoparticles for high-throughput genotyping of long-range haplotypes. Nature Nanotechnology, v. 6, n. 10, p. 639-644, 2011.

115 ZHANG, X.; TENG, Y.; FU, Y.; XU, L.; ZHANG, S.; HE, B.; WANG, C.; ZHANG, W. Lectin-based biosensor strategy for electrochemical assay of glycan expression on living cancer cells. Analytical Chemistry, v. 82, n. 22, p. 9455 - 9460, 2010. 
116 ABAD-VALLE, P.; FERNÁNDEZ-ABEDUL, M. T.; COSTA-GARCÍA, A. DNA single-base mismatch study with an electrochemical enzymatic genossensor. Biosensors and Bioelectronics, v. 22, n. 8, p. 16421650, 2007.

117 LA-SCALEA, M. A.; SERRANO, S. H. P.; GUTZ, I. G. R. Eletrodos modificados com DNA: uma nova alternativa em eletroanálise. Química Nova, v. 22, n. 3, p. 417-424, 1999.

118 CHEONG, S.-K.; JONES, B. L.; SIDDIQI, A. K.; LIU, F.; MANOHAR, N.; CHO, S. H. X-ray fluorescence computed tomography (XFCT) imaging of gold nanoparticle-loaded objects using $110 \mathrm{kVp} x$-rays. Physics in Medicine and Biology, v. 55, n. 3, p. 647, 2010.

119 MACIEL, A. C. Propriedades elétricas de sólidos desordenados: aplicação em estruturas metal/polímero/metal. 2006. 56 p. Trabalho de Conclusão de Curso (Bacharelado em Física) Universidade Federal do Piauí - UFPI, Departamento de Física, Teresina, 2006.

120 LISDAT, F.; SCHAEFER, D. The use of electrochemical impedance spectroscopy for biosensing. Analytical and Bioanalytical Chemistry, v. 391, n. 5, p. 1555-1567, 2008.

121 CHANG, B.-Y.; PARK, S.-M. Electrochemical impedance spectroscopy. Annual Review of Analytical Chemistry, v. 3, n. 1, p. 207-229, 2010.

122 BONANNI, A.; ISABEL PIVIDORI, M.; CAMPOY, S.; BARBE, J.; DEL VALLE, M. Impedimetric detection of double-tagged PCR products using novel amplification procedures based on gold nanoparticles and Protein G. Analyst, v. 134, n. 3, p. 602-608, 2009.

123 GEBALA, M.; STOICA, L.; NEUGEBAUER, S.; SCHUHMANN, W. Label-free detection of DNA hybridization in presence of intercalators using electrochemical impedance spectroscopy. Electroanalysis, v. 21, n. 3-5, p. 325-331, 2009.

124 CANCINO, J.; MACHADO, S. A. S. Microelectrodes array in mixed alkanethiol self-assembled monolayers: electrochemical studies. Electrochimica Acta, v. 72, n. 1, p. 108-113, 2012.

125 POGHOSSIAN, A.; CHERSTVY, A.; INGEBRANDT, S.; OFFENHÄUSSER, A.; SCHÖNING, M. J. Possibilities and limitations of label-free detection of DNA hybridization with field-effect-based devices. Sensors and Actuators B: chemical, v. 111-112, p. 470-480, 2005. DOi:10.1016/j.snb.2005.03.083

126 STINE, R.; ROBINSON, J. T.; SHEEHAN, P. E.; TAMANAHA, C. R. Real-time DNA detection using reduced graphene oxide field effect transistors. Advanced Materials. v. 22, n. 46, p. 5297-5300, 2010.

127 WIRTH, J. Color Atlas of Genetics. San diego: George Thieme Verlag, 2001. 


\section{APÊNDICES}

\section{Apêndice A - Divulgação Científica e Tecnológica}

\section{Apresentações do trabalho}

O trabalho foi apresentado na forma de pôster no X e XI Brazilian MRS Meeting da Sociedade Brasileira de Pesquisa em Materiais - SBPMat, no Workshop anual do Instituto Nacional de Eletrônica Orgânica - INEO, no $2^{\circ}$ encontro da Rede Nanobiomed, na I e II Semana Integrada da Física - SIFSC, na II USP Conference on Nanotechnology e na I Feira de Inovação e Empreendedorismo - USPiTec. O trabalho também foi divulgado na forma de palestra no $4^{\circ}$ Café da Biotec Farma, evento realizado pela Interfarma e a Biominas, que visa promover a interação e o diálogo entre indústrias farmacêuticas e empresas de biociências. Além de apresentação em formato de palestra no $7^{\circ}$ Congresso Internacional Científico UNIARARAS, a convite da Fundação. É importante ressaltar que eventos como esse são essenciais para a divulgação do nosso trabalho, e em especial dessa nossa nova linha de pesquisa em genossensores. Além é claro de possíveis colaborações de sucesso.

Resumos publicados em anais de congressos

ROLIM, Thalita; Zucolotto, Valtencir. Gold nanoparticles functionalized with oligonucleotides for application as genosensors in the advanced diagnosis of blood hypertension. In: SOCIEDADE BRASILEIRA DE PESQUISA EM MATERIAIS, SBPMat.; BRAZILIAN MRS MEETING, 10., 2011. Gramado. Resumos... Gramado: SBPMat, 2011.

ROLIM, Thalita; ZUCOLOTTO, Valtencir. Synthesis and functionalization of nanoparticles with oligonucleotides for application as genosensors in the early diagnosis of blood hypertension. In: INSTITUTO NACIONAL DE ELETRÔNICA ORGÂNICA, INEO, Workshop Anual, 2011. Atibaia. Resumos... Atibaia: INEO, 2011. 
ROLIM, Thalita; ZUCOLOTTO, Valtencir. Utilização de nanopartículas funcionalizadas com DNA na construção de genossensores. In: Rede NANOBIOMED, encontro, 2., 2001. Águas de São Pedro. Resumos... Águas de São Pedro: Rede NANOBIOMED, 2011.

ROLIM, Thalita; ZUCOLOTTO,Valtencir. Development of genosensors containing functionalized oligonucleotides and AuNPs for early diagnosis of blood hypertension. In: SIFSC, Semana Integrada da Física, 1., 2011. São Carlos. Resumos... São Carlos: SIFSC, 2011.

ROLIM, Thalita; CANCINO, Juliana; ZUCOLOTTO, Valtencir. DNA detection using AuNPs/oligonucleotides nanocomplexes. In: SOCIEDADE BRASILEIRA DE PESQUISA EM MATERIAIS, SBPMat.; BRAZILIAN MRS MEETING, 11., 2012. Florianópolis. Resumos... Florianópolis: SBPMat, 2012.

ROLIM, Thalita; CANCINO, Juliana; ZUCOLOTTO, Valtencir. DNA Detection using AuNPs-oligonucleotide nanocomplexes in a genosensor device. In: SIFSC, Semana Integrada da Física, 2., 2012. São Carlos. Resumos... São Carlos: SIFSC, 2012.

ROLIM, Thalita; CANCINO, Juliana; ZUCOLOTTO, Valtencir. Developing a Nanostructured Genosensor for Early Diagnosis of Systemic Arterial Hypertension. In: Conference on Nanotechnology, 2. 2012. Itirapina. Resumos... Itirapina: Conference on Nanotechnology, 2012.

Apresentações Orais

ROLIM, Thalita; ZUCOLOTTO,Valtencir. Genossensor para diagnóstico avançado da hipertensão arterial utilizando conjugados contendo nanopartículas e DNA. In: Biotec Farma, 4. 2011. São Carlos. Palestra... São Carlos: Biotec Farma 2011.

ROLIM, Thalita; ZUCOLOTTO,Valtencir. In: $7^{\circ}$ Congresso Internacional Científico UNIARARAS. Araras, São Paulo, 14 de Junho de 2012. Palestra... Araras: $\quad 7^{\circ}$ Congresso Internacional Científico UNIARARAS 2012.

Artigos

ROLIM, Thalita; CANCINO, Juliana; ZUCOLOTTO, Valtencir. A Nanostructured genosensor for the early diagnosis of systemic arterial hypertension. Analytical Chemistry (submetido). 
ANEXOS

Anexo A - Mapa gênico

Gene enzima conversora de angiotensina 1 (ECA) ID: 1636

HOMO SAPIENS ANGIOTENSIN I CONVERTING ENZYME (PEPTIDYL-
DIPEPTIDASE A) 1 (ACE), REFSEQGENE ON CHROMOSOME 17

NCBI Reference Sequence: NG_011648.1

$\underline{\text { FASTA Graphics }}$

Go to:

LOCUS NG_011648 21320 bp DNA linear PRI 11-MAR-2011

DEFINITION Homo sapiens angiotensin I converting enzyme (peptidyl-dipeptidase A) 1 ( $\mathrm{ACE})$, RefSeqGene on chromosome 17.

ACCESSION NG 011648 REGION: 4989..26308

VERSION NG_011648.1 GI:225543278

KEYWORDS RefSeqGene.

SOURCE Homo sapiens (human)

ORGANISM Homo sapiens

Eukaryota; Metazoa; Chordata; Craniata; Vertebrata; Euteleostomi; Mammalia; Eutheria; Euarchontoglires; Primates; Haplorrhini; Catarrhini; Hominidae; Homo.

COMMENT REVIEWED REFSEQ: This record has been curated by NCBI staff. The reference sequence was derived from Ac113554.9.

This sequence is a reference standard in the RefSeqGene project.

Summary: This gene encodes an enzyme involved in catalyzing the conversion of angiotensin I into a physiologically active peptide angiotensin II. Angiotensin II is a potent vasopressor and aldosterone-stimulating peptide that controls blood pressure and fluid-electrolyte balance. This enzyme plays a key role in the renin-angiotensin system. Many studies have associated the presence or absence of a $287 \mathrm{bp}$ Alu repeat element in this gene with the levels of circulating enzyme or cardiovascular pathophysiologies. Multiple alternatively spliced transcript variants encoding different isoforms have been identified, and two most abundant spliced variants encode the somatic form and the testicular form, respectively, that are equally active. [provided by RefSeq] . 


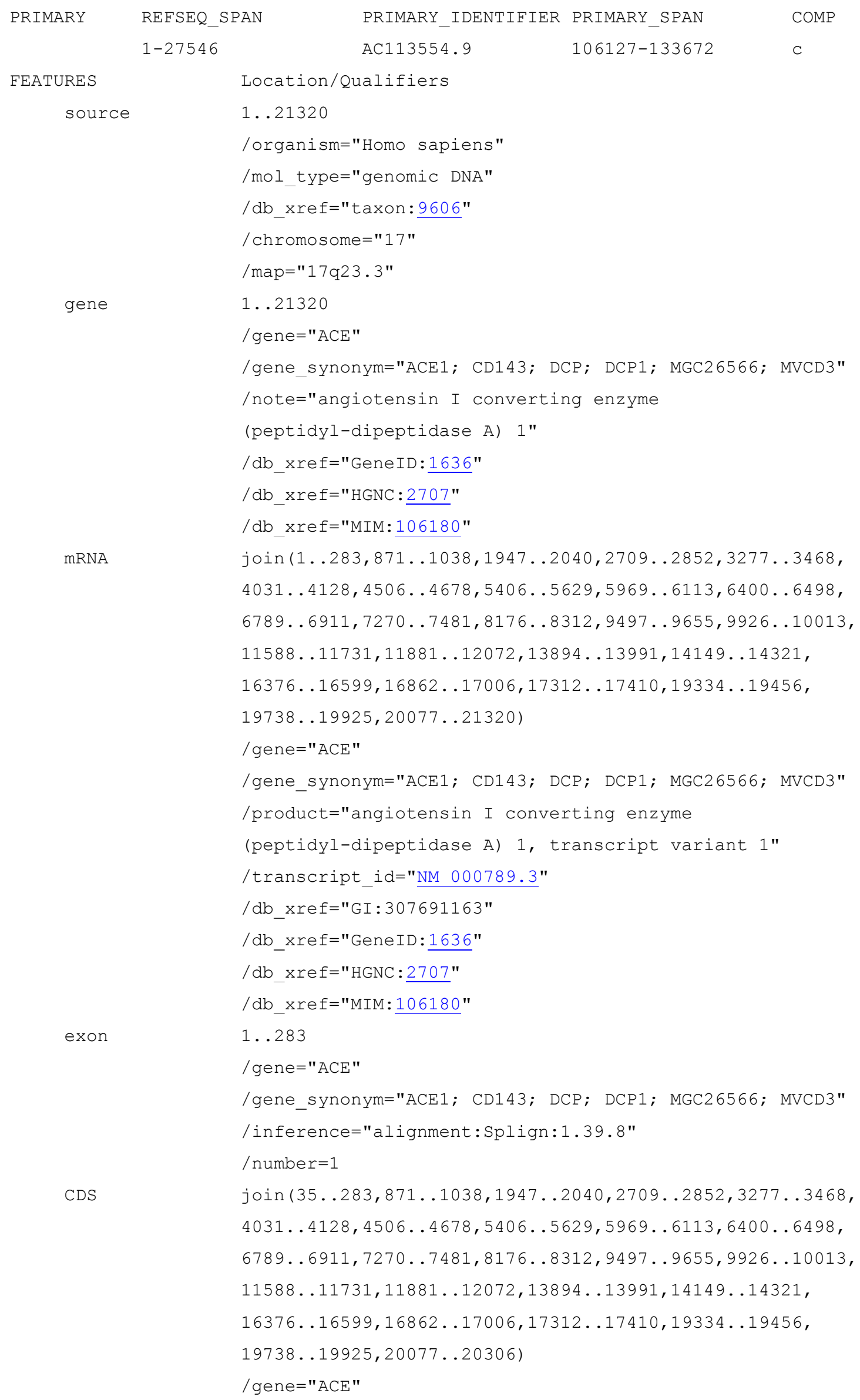


exon

exon

exon

exon

exon

exon
/gene_synonym="ACE1；CD143；DCP；DCP1；MGC26566；MVCD3" /EC_number="3.4.15.1"

/note="isoform 1 precursor is encoded by transcript variant 1; kininase II; CD143 antigen; angiotensin

converting enzyme, somatic isoform; peptidase P; carboxycathepsin; dipeptidyl carboxypeptidase 1; testicular ECA; dipeptidyl carboxypeptidase I"

/ codon_start=1

/product="angiotensin-converting enzyme isoform 1

precursor"

/protein_id="NP $000780.1 "$

/db_xref="GI: $4503273 "$

/ db_xref $=" C C D S: C \operatorname{CDS} 11637.1 "$

/db_xref="GeneID: $1636 "$

$/$ db_xref $=" H G N C: \underline{2707 "}$

$/ \mathrm{db}$ _xref="MIM: $106180 "$

$871 \ldots 1038$

/gene="ACE"

/gene synonym="ACE1；CD143；DCP； DCP1; MGC26566；MVCD3" /inference="alignment:Splign:1.39.8"

/ number $=2$

$1947 \ldots 2040$

/gene="ACE"

/gene_synonym="ACE1；CD143；DCP；DCP1；MGC26566；MVCD3" /inference="alignment:Splign:1.39.8"

/ number $=3$

2709.2852

/gene="ACE"

/gene_synonym="ACE1；CD143；DCP；DCP1；MGC26566；MVCD3" /inference="alignment:Splign:1.39.8"

/ number $=4$

$3277 \ldots 3468$

/gene="ACE"

/gene_synonym="ACE1；CD143；DCP；DCP1；MGC26566；MVCD3" /inference="alignment:Splign:1.39.8"

/ number $=5$

$4031 \ldots 4128$

/gene="ACE"

/gene_synonym="ACE1；CD143；DCP；DCP1；MGC26566；MVCD3" /inference="alignment:Splign:1.39.8"

$/$ number $=6$

$4506 \ldots 4678$

/gene="ACE"

/gene_synonym="ACE1；CD143；DCP；DCP1；MGC26566；MVCD3" 


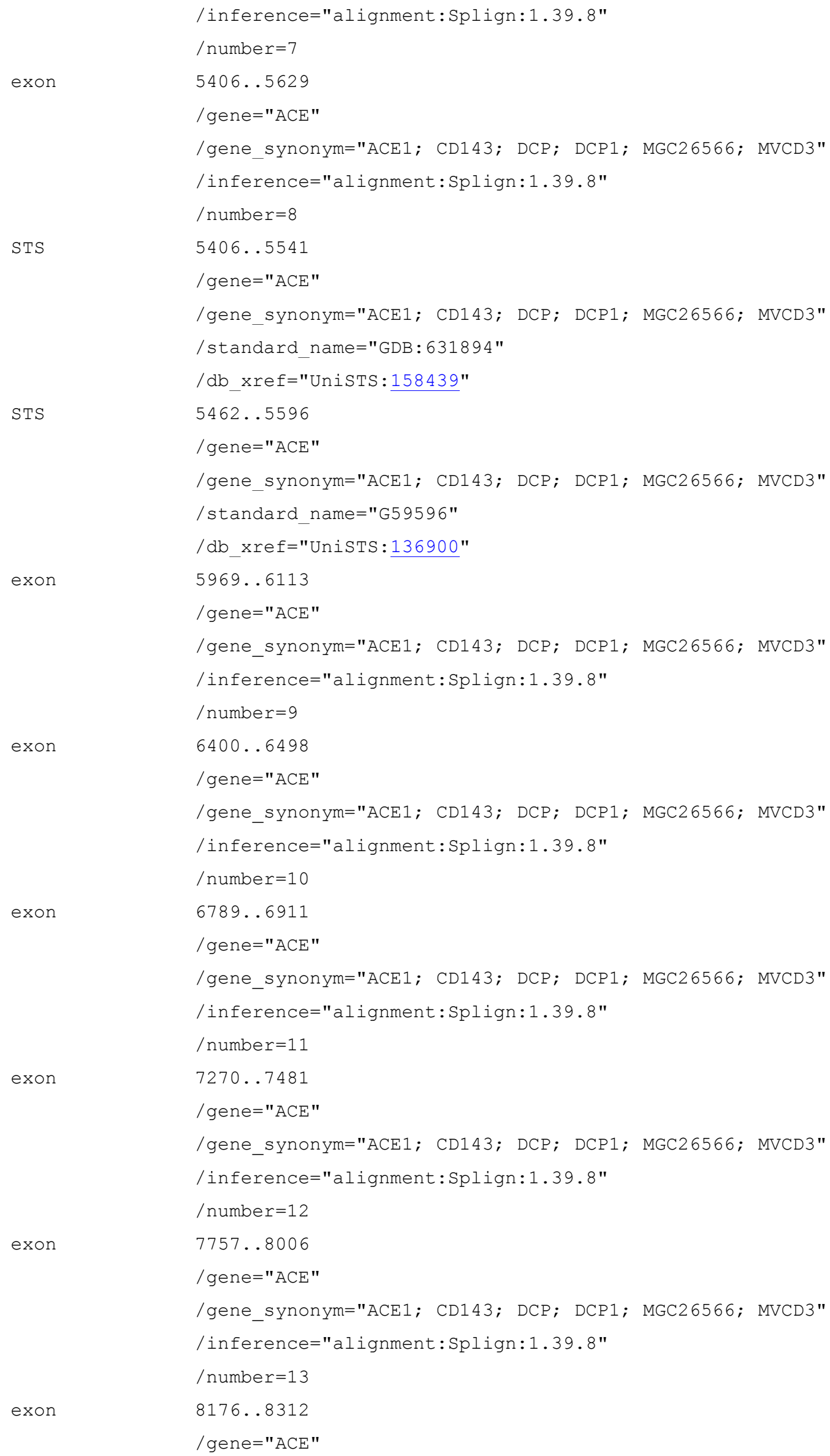


/gene_synonym="ACE1；CD143；DCP；DCP1；MGC26566；MVCD3"

/inference="alignment:Splign:1.39.8"

/ number $=14$

exon

STS

exon

STS

exon

exon

exon

exon
9497.9655

/gene="ACE"

/gene_synonym="ACE1；CD143；DCP； DCP1；MGC26566； MVCD3" /inference="alignment:Splign:1.39.8"

/ number $=15$

$9548 \ldots 9690$

/gene="ACE"

/gene synonym="ACE1；CD143；DCP； DCP1; MGC26566；MVCD3" / standard_name="PMC310924P2"

/db_xref="Unists:272813"

$9926 \ldots 10013$

/gene="ACE"

/gene_synonym="ACE1；CD143；DCP；DCP1; MGC26566; MVCD3" /inference="alignment:Splign:1.39.8"

/ number $=16$

$11422 \ldots 11612$

/gene="ACE"

/gene_synonym="ACE1；CD143；DCP；DCP1；MGC26566；MVCD3" / standard_name="GDB:186915"

/db_xref="UnistS: $\underline{155520 "}$

$11588 \ldots 11731$

/gene="ACE"

/gene_synonym="ACE1；CD143；DCP；DCP1；MGC26566；MVCD3" /inference="alignment:Splign:1.39.8"

/ number $=17$

$11881 \ldots 12072$

/gene="ACE"

/gene_synonym="ACE1；CD143；DCP； DCP1; MGC26566； MVCD3" /inference="alignment:Splign:1.39.8"

/ number $=18$

$13894 \ldots 13991$

/gene="ACE"

/gene_synonym="ACE1；CD143；DCP； DCP1; MGC26566； MVCD3" /inference="alignment:Splign:1.39.8"

/ number $=19$

$14149 \ldots 14321$

/gene="ACE"

/gene synonym="ACE1; CD143; DCP; DCP1; MGC26566; MVCD3" /inference="alignment:Splign:1.39.8"

/ number $=20$

$14157 \ldots 14313$ 


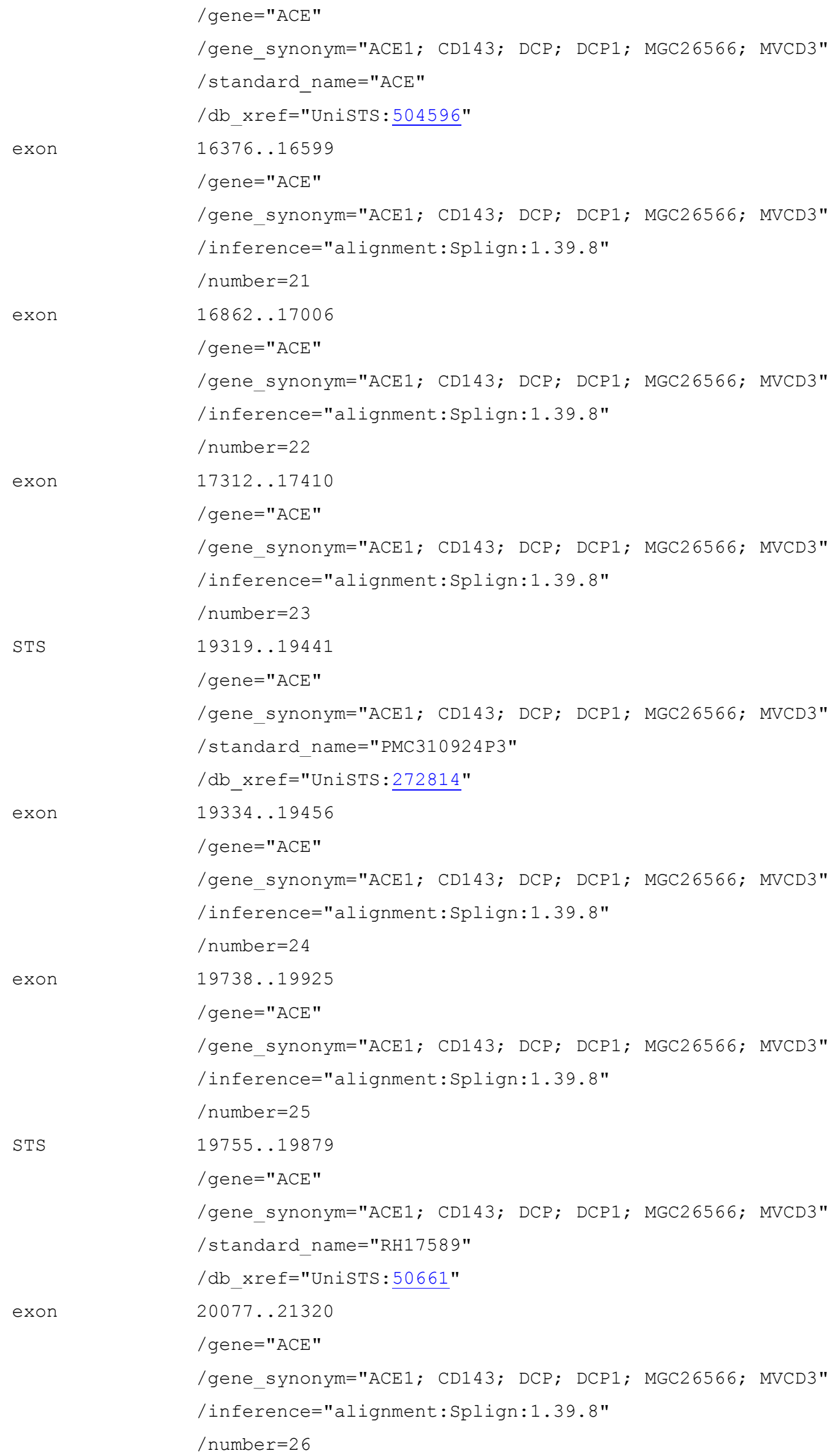


/gene_synonym="ACE1；CD143；DCP；DCP1；MGC26566；MVCD3" / standard_name="SHGC-57821"

/db_xref="UnistS: 19461"

ORIGIN

1 agaaggggca gagccgagca ccgcgcaccg cgtcatgggg gccgcctcgg gccgccgggg

61 gccggggctg ctgctgccgc tgccgctgct gttgctgctg ccgccgcagc ccgccctggc

121 gttggacccc gggctgcagc ccggcaactt ttctgctgac gaggccgggg cgcagctctt

181 cgcgcagagc tacaactcca gcgccgaaca ggtgctgttc cagagcgtgg ccgccagctg

241 ggcgcacgac accaacatca ccgcggagaa tgcaaggcgc caggtgggcg cccgggcccg

301 ggcgggggcg gggcggggce gcggcggcca atcacagcac gcggccggct tgtggggcgg

361 gcaggctggc gcccccgacc cgaaccccac cccgaccccg gaccctcgcc ccgacagtca

421 gccgcggggc ccgagcgecg ggctgcgcgc acggcctgcg ctcccagcat gcacgagttg

481 gatggatgag ggtggctgct cccaggccgc gcccgccttc gccgaaggtg ctgggcttgg

541 ctctggggcc cccgcgctct cgggcagctg cettctcacc tccggacgct gtcgctgtca

601 ccgtcaccgc actgcactgt ccatccaccc tccactcgec cggcctctt tctggtccca

661 atttctgctc caccattccc atgaggcaga ttccctccag aaggaggaag cgcggcttcc

721 gcaaactaag gtctcccgca gggatctccc cagggcccgg gctctggaag cccttggcct

781 tcctcccetc ccccagcacc gtggettctc ctttatggec tgcatctaag cagggtccta

841 caccctccct gccctcctgg tgcccaatag gaggaagcag ccctgctcag ccaggagttt

901 gcggaggcct ggggccagaa ggccaaggag ctgtatgaac cgatctggca gaacttcacg

961 gacccgcagc tgcgcaggat catcggagct gtgcgcaccc tgggctctgc caacctgccc

1021 ctggctaagc ggcagcaggt gggctgaggg ctgaggcaga gctcgggggc ggcctcctag

1081 tgccccatcg tgggggtcgg gggagagcag cccatcaggg agggaggaac cctgggatcc

1141 acatgggccc tgacagaagg gaaagcccag gtaagcacag aatggctttc tgagcattga

1201 tttttcttgg agatggggtg gggagttact ttctgttaaa ggaagcattc tggagtagga

1261 agccaaattc aaatacactt ctccctaggc tggtttatga gcttctttgg aagagttgag

1321 aagggctggg cgtggtggct caagcctgta atcccagcac tttgggaggc tgaggtgggc

1381 gcatcgcttg agcccaggag ttcaagacca gcctggccaa catggcaaaa cctcgtctct

1441 acaaaaaaa aatagctggg cttggtggtg cgtgcaccta cagtcccagc tactcttgaa

1501 actgaggggg aaggatcacc tgagcccagg aggtcaaggc tacagtgagc tgtgattgca

1561 ctactgcacc ccagcctgcg tgacagagtg agacctcccc ccaaaaaaa gagagagaga

1621 aaaggttgag aaagactggg aagtcaccaa agccagagaa tgggagggat ctgccctcac

1681 tgcagggtgg tgccaagctg ggacttgacc ctgaccctga ctttcaggac tcctgtcccc

1741 cactccacag gctgcctcca ctggcagggg actcagaagt gatccggtca cactaagtga

1801 cacttagtga tcagaagtgc cccggtgcca ctgagtggcc ttgtccaagc tacatccact

1861 ctgtgggctc ctccttctag cagcgagggg agggcagatg tcccaggggc tggtcactgg

1921 agcattcctc ccctctgact ccccagtaca acgccetgct aagcaacatg agcaggatct

1981 actccaccgc caaggtctgc ctccccaaca agactgccac ctgctggtcc ctggacccag

2041 gtacggccet tgcagctccc ctctcggcgg tgccetagtg ttcccacatt gccetgctgc

2101 actccagacc atgcagttgt gtagggtctg tggagacagc aggtaaaccc aaaggtgttg

2161 ccctccaact ggggctggac ggtgcagata cccccacgcc ctgcttctct tggcaagtgg

2221 acttccggaa tctccagctg cagcccccac ttctgtgtgt acctcggcct ctcccatcac 
2281 ccctaggect tcctcctggc tgcetggttt cecetttcgt gggtcctctc atgttcccca 2341 agagccctca ggccagggac ccctcgtggc ttcccettaa accccgctcc agccccctt 2401 atgagcagct tcgaggaagg cactccatcc aataggcegc taagtgtctg tctgggttt 2461 ggcettggg tgtccccttg gtgtcagcca ccttaggtgg tcatgtctct ggggcagggg 2521 ccctgcctgg gtgtttctgt agctcccagc cccctcccac caggcctgta ggtggcccet 2581 gtctctgggg gcaccgtgat gttcaggaag ctggtgggag cagtaaggac tggtgcaggc 2641 tctggtgaag gccgttgaag acttcaacgt ggaggcctcc tcaccgaccc tgcctgcctg 2701 tgtctcagat ctcaccaaca tcctggcttc ctcgcgaagc tacgccatgc tcctgtttgc 2761 ctgggagggc tggcacaacg ctgcgggcat cccgctgaaa ccgctgtacg aggatttcac 2821 tgccctcagc aatgaagcct acaagcagga cggtgagcag gcctctccct gtccaggaac 2881 cacgccaggt gtcctctctc agctgtctcc ccagagtccc agcccagagt caggcagagc 2941 agctggtatg acaattccag caggccctga gtttcccaga aagtggaggt gggaccggcc 3001 tgcacccagt gtgcctggac tttgctgctg gcctgcccca cgtggccatc ctgctgtcac 3061 tcctggccct gatgctcctc tttgcctctg ggaacctcca ggatctgttt agctggctgt 3121 agctaattag aaattgtaga gtggcaaccc ccaagccaat tttccagcta gctgcagatc 3181 cacgggcctc gagccagtgg aagagccgac ttacagctga gaggctgagg tccgagcctt 3241 tggcetgagc tacatacctc acccccacgc ccccaggctt cacagacacg ggggcctact 3301 ggcgctcctg gtacaactcc cccaccttcg aggacgatct ggaacacctc taccaacagc 3361 tagagcccet ctacctgaac ctccatgcct tcgtccgccg cgcactgcat cgccgatacg 3421 gagacagata catcaacctc aggggaccca tccctgctca tctgctgggt aaggacctgg 3481 cctcgcctcc acatgagtcc cacggaagtg tgggtcccga ggtaggggtg ggggatgtcc 3541 agggtaaggg aaggtgggtt gtgaccctca catctcacat gtgtggggca tcatactgtt 3601 tgcttcacat gcaggagacc attcgtgttc ccactttaca ggtggggacc ctgaggctta 3661 gggtcgtgag ggacttagtg gtcagagagc taggggccaa accaaaggct ctggccctgg 3721 gtccagtggg ggagccatca gcctagctca tgcccaagga aacaagcact gtggccctgc 3781 ctcaggattg agtggctggg gcctggcaca gccagaaatg acagtggcag catcttgcag 3841 ccccaggaca tgtggccctc ggaggagtgt gggtgggact gatgtgtgag atttctggcc 3901 ctaagccagg cctgcagccc ttgagggccc cagggtacag gtgccggccc cagggtgcca 3961 ctcagcgatg catgaagaag caggcacagc caggcaggga gccaagctgt ccccttcctt 4021 ccttatctag gagacatgtg ggcccagagc tgggaaaaca tctacgacat ggtggtgcct 4081 ttcccagaca agcccaacct cgatgtcacc agtactatgc tgcagcaggt aagctctggg 4141 ctcaagcctg gggtggtggg ggtcgggggt ggggcgcaaa aaaagggagt cacagatggg 4201 cacaggggcg ggaaggtttc gggtactgag cagcagcctg gtgtgtctgt aggagcagtg 4261 agctggggtc ggccccctca gtgaggtgcc agctcctccc tccaggctcc acagtggcag 4321 gatgagagca acaacgcact ttcactcatc tgctgtggga gtgagggcce tgcetctggg 4381 aatggtggcc acagagcaga gaagctttca tgcacaggga gttgacccga gatggggacc 4441 ccagccctgt ccccaggcca gccagagtgg gctccccctg acctggctcc acacccctcc 4501 tccagggctg gaacgccacg cacatgttcc gggtggcaga ggagttcttc acctccctgg 4561 agctctcccc catgcctccc gagttctggg aagggtcgat getggagaag ccggccgacg 4621 ggcgggaagt ggtgtgccac gcctcggctt gggacttcta caacaggaaa gacttcaggt 4681 tcagacatgg gaagagcacg ttctggggtt ccccggttct ggggcccggg gaaaggcagg 4741 cagcccaggc gcagggaagc tggttcccag gcctgcctct accctacccc agcactggtt 4801 ggaggctggg tctgttccag ggctaggggg tataggaggc ctattagtcc accttctctg 4861 gcagctttga caaatagtca cttctatacc ttggaatgga ggaagaaggc ccaagtggtg 
4921 gtgagccagg gcagggtaaa gaatttgctt gtttctgcca ggcacggtgg tcacacctgt 4981 aatcccagca ctttgggagg tcaaggcggg tggatcacct gaggccagga gttcgagacc 5041 agcetggcca acatggcgaa accccgtctc tactaaaat acaaaataa attagccagg 5101 ggtgatggcg ggcgcctgta atcccagcta ctcaggaggc tgaggcagga gaatctcttg 5161 aacccgggag gcggaggttg cagtgagctg agattgtgcc actacaggcc agcctgtgca 5221 aaagagtgag acgctgtctc aaaaaaaaa aagaaaaaa gaagttactt gtttctactg 5281 cggcttcatg ccccagggca getccetcet cattcctgtc tttcaggtgc caatctgccc 5341 tgtgccetgg ccctgccctg ttctgtccat ccgtcactct caccctcgcc ctctctacgc 5401 cccaggatca agcagtgcac acgggtcacg atggaccagc tctccacagt gcaccatgag 5461 atgggccata tacagtacta cctgcagtac aaggatctgc ccgtctccct gcgtcggggg 5521 gccaaccccg gcttccatga ggccattggg gacgtgctgg cgctctcggt ctccactcct 5581 gaacatctgc acaaatcgg cctgctggac cgtgtcacca atgacacggg tatgggaggg 5641 ctgagaggcc cccacccagc ctcacctaal ccccgctcca ccccacagca ggacctcact 5701 tgccceactc agctctgccc ttctttctgc ctcccggccc caggtcaggc agggttcggg 5761 atcctcctag agcctcacgg tgcacactgc gcccagctca gcacacctgg gggtcctctt 5821 ccaagcaggg cccagggtct cgagggccag ccataccttc tctgcatctc cctggcctca 5881 ctttctgctg ccccgccagc ccacactctt aggggaccet cttctccctc tgacctcttc 5941 cctctcctt catctcatct cccaacagaa agtgacatca attacttgct aaaatggca 6001 ctggaaaaa ttgccttcct gccetttggc tacttggtgg accagtggcg ctggggggtc 6061 tttagtgggc gtaccccccc ttcccgctac aacttcgact ggtggtatct tcggtgagag 6121 gagggataga aaagccttcg ccccagctag ccctccccag cctcctggac agccaggcgc 6181 ctcctgcccc agccagttct agcctctcct ctctaatgat gtcccccget gtgacccacc 6241 gcctctcct ttcctgcctg aaactccctc ttccaggaag tcttccccag ttcctcagga 6301 tggggaaggg ttgccgggtg gaaatgcctt ttctacaaaa gttaaatcca tctgtttgca 6361 acctctaggc cctaagacaa tttaaccatc cttttccaga accaagtatc aggggatctg 6421 tcctcctgtt acccgaaacg aacccactt tgatgctgga gctaagtttc atgttccaaa 6481 tgtgacacca tacatcaggt attagcgccc ccaccccacc cacccccagt actgtcacac 6541 cctcaatcca cttctcctcc tgtgatccta gctgcctcat ccccagggct tgtccccatg 6601 ctcctccaga cctcaaaggc ctggagttag agtggcccac tctcctgagc ctgtcttggg 6661 tctccettct cccccargat agcttctggt ccagcctctg ccctgcagga agctggatgg 6721 tgcetgggta aggaacccet gttcctggce ccccatgatc ttccetgact cccaccctgt 6781 gcctgcaggt actttgtgag ttttgtcctg cagttccagt tccatgaagc cetgtgcaag 6841 gaggcaggct atgagggccc actgcaccag tgtgacatct accggtccac caaggcaggg 6901 gccaagctcc ggtgtgtggt gggaagccgg gggaagtggg aggcagagag gagcggctgg 6961 caaagggtgt ggcaggaggt gtctggctgc tctgatgggg tggggggcac caaccacaga 7021 gctggactga tgtggatgcc tgtctcctcg ctatgtcatc aaatatttat tgagtgggcc 7081 ttctggctgg catggggcga cacaaatgcc ccctgccacc atcagagaga tcccaggccc 7141 cagggtctta ttgccacagt ttctgcagtc cattgggggg cggaagtggc caggggcatg 7201 tgggccgggg tccaggagca gactccagcc tgagtcccet gtgcceatgg tacccactct 7261 gcccaccagg aaggtgctgc aggctggctc ctccaggcce tggcaggagg tgctgaagga 7321 catggtcggc ttagatgcce tggatgccca gccgctgctc aagtacttcc agccagtcac 7381 ccagtggetg caggagcaga accagcagaa cggcgaggtc ctgggctggc ccgagtacca 7441 gtggcacccg ccgttgcctg acaactaccc ggagggcata ggtaaagccc tgagtgagga 7501 tggtgtgggg ctaaggtggg tcctcaactc tgggcttggc ccaggcccca ggttcctggt 
7561 cagctcctac cagctgagcc ctggtaccct gtcctggagg gccaggcagc cccccaagct 7621 catcagcagg gcctgcgagt ggggacaggc atgtctttcc cccagcatcc tagagagggt 7681 gtgctcagac ctgagggccc ctcccettcc agaggaagcc agacacaagg ctctgtgagg 7741 tcacactgcg ggctccgctc ttattggcca ggggacggta gctgcaggac tctgctctcc 7801 tgcggccatg ggccagggtt gggctactgc aggacttccc agcctcctct tcctgctgct 7861 ctgctacggg caccctctgc tggtccccag ccaggaggca tcccaacagg tgacagtcac 7921 ccatgggaca agcagccagg caacaaccag cagccagaca accacccacc aggcgacggc 7981 ccaccagaca tcagcccaga gcccaagtgg gaccatgcag gggaggggca gggtgccagg 8041 ggtgggagag gcggggccgg gtagggacag ggcagggtac aagggagtgc gagagggata 8101 atggcttctg gtgagaccac aaacctggag aggggaggca gaggtttgtc tgtttccctg 8161 cactctgtcc cacagacctg gtgactgatg aggctgaggc cagcaagttt gtggaggaat 8221 atgaccggac atcccaggtg gtgtggaacg agtatgccga ggccaactgg aactacaaca 8281 ccaacatcac cacagagacc agcaagattc tggtgggagc cacctcccca cccccaaacc 8341 tgagcatgtg catacacaca gagatgctgt cccgctcacc acacagtggg gctgccacca 8401 catttaaat tgaatattta aacaatact caatttcggg ccgggcgcgg tggctcacgc 8461 ctgtaatccc agcactttgg gagggggagg cgggcggatc acgaggtcag atcaagacca 8521 tcctggctaa cacggtgaaa ccccatctct agtaaaata caaaattag ccgggtgtgg 8581 tggcgagcac ctgtagtccc agtactcagg aggctgaggc aggagaatgg catgaacccg 8641 ggaggcagag cttgcagtga gccgagatgg caccactgca ctccagcctg ggcgacagag 8701 cgagactcca tcaaaaaaa aaaaaaaaa aactcaattt cagattttga tgaacattta 8761 ctcaatgcct gagcaattct tctttcctta aaaatcagtc tctgggaggc ctaggtggga 8821 ggatcacttg aagccaggag ttggagacta gcctgggcaa catagcaaga tcccatctct 8881 attcaaacaa acaaataac aaaatcaat ctctagtaac agaataattt gtacataat 8941 aagtggtgct caagtcgttt tttaaaagat tgaaagcctc tgtttgtctc ctctacaaaa 9001 ggggctacac ttcctcttta ccctcattcc ctgcctattt ggctgagcac aattatgcc 9061 actgagccac acactgttac tgttccttgg cactttgatc tgttgcctca tcttttctc 9121 aacagccttg caaaltggt gagcttattc ccattttaca gatgggattt gatattaact 9181 ctgaggttca gaaaggccac agagctaata ccaagctggc tccttcctaa gggcctttac 9241 gacacttggg ggtcttctct tctctgcccc tgcctggata tgtgttgctt gaccgcaggc 9301 atccagggag ggtgagtact gcatccagga cgttatcagc gtccagcttg cagagagtct 9361 tataggcaaa ggttgcaact taattccact gccccctcac caccacctcc agccctcagc 9421 tcccacttgg ggcctcccgc tcagaggctg ctctggagct cctgggccct gtgacaccat 9481 ccccctgtgc cctcagctgc agaagaacat gcaatagcc aaccacaccc tgaagtacgg 9541 cacccaggcc aggaagtttg atgtgaacca gttgcagaac accactatca agcggatcat 9601 aaagaaggtt caggacctag aacgggcagc actgcctgcc caggagctgg aggaggtgtg 9661 tggctcgcaa ggtacaggga gaggggaatc ctggggcagt gagcccaaca cagggtctgg 9721 cctggccttc acgctgcttc ctcttcctcg ttgtatcaag tcatggcatc tgccatgcga 9781 tgtgcacctc agaactgctg agagggcagc gctccccagc tccetggctc cccacctgcc 9841 agcccatggg gcctgggggt agtgcaggcc ccagagagac caagtgcaaa ggagtacagc 9901 tcattgcctc tccttcctcc tgcagtacaa caagatcctg ttggatatgg aaaccaccta 9961 cagcgtggcc actgtgtgcc acccgaatgg cagctgcctg cagctcgagc caggtgagag 10021 ctcatgtgca ggctgagtga gaggcgaggg ctgggactgg catggggccc gggggtgctg 10081 ggtgagagca cagagttggg ttcccctcgc tcttggggtc agcgtgccca ggaatgccc 10141 tttcttgtt tccacgaggg gggcttctct gccccactga gagccggcac ctacttcata 
10201 ccatgccecg atcagctgcc cetccetcag aaccgccetc tgcttaaggg tgtccactct 10261 ctcctgtcct ctctgcatgc cgcccetcag agcagcggga tctcaaagtt atatttcatg 10321 ggcttggact ccaaatgggg ggaactcggg gacactagct ccccccggcc tccttegtg 10381 accetgccet tgacttcctc accttctctg tctttcctga geccetctcc cagcatgtga 10441 ctgataagga aattgagtca cacagcccet gaaagcgcca gactagaacc tgagcctctg 10501 attcctctca cttccetcac ctaccetgcc acttcctact ggatagaagt agacagctct 10561 tgactgtcct ctttctccc cactggctgg tccttcttac cccggccegt ttgaaagagc 10621 tcacccccga cacaaggacc cgcacacaga tacctcccag ctccctctca acccaccct 10681 tccagggttg gagaacttga ggcataaact tgcttccatg aggaatctcc acccagaat 10741 gggtctttct ggcccccagc ccagctccca cattagaaca atgacaaata gaaggggaaa 10801 tggaaaataa acaggagaaa cggttttccc aggacagggt ttggcctaca agttgtggat 10861 gtgggtacc atgccaagtg tgaggggagg ctggccgggt gtggtggctc atgcctctaa

Intron $16 \quad 10921$ tcccagcact ttgggaggcc aaggtgagta gatcacttga ggcegggagt ttgagaccag 10981 cctggccaac atggtgaaac cccatctgta ctaaaatac aaaagttagc tgggcgtggt 11041 ggtagatgcc tgtagtccca gctacttggg aggctgaggc atgagaatcg cttgagccca 11101 gcctgggcaa tacagcaaga ccccgtctct acaaataaaa tacaaaaat tagttggatg 11161 tggtggtgca tgcctgtagt cctagctgct agggaggctg agatggaagg attgcttgag 11221 cctgggaggt caaggctgca gtgagccgag atggcgccac tgcactccag cetgggcaac 11281 agagtgagac cctgtctcag aaaaaaaaa aaaaaaaaa aggagaggag agagactcaa 11341 gcacgcccct cacaggactg ctgaggccet gcaggtgtct gcagcatgtg gecccaggcc 11401 ggggactctg taagccactg ctggagagcc actcccatcc tttctcccat ttctctagac 11461 ctgctgccta tacagtcact tttatgtggt ttcgccaatt ttattccagc tctgaaatc 11521 tctgagctcc ccttacaagc agaggtgagc taagggetgg agctcaagge attcaaaccc 11581 ctaccagatc tgacgaatgt gatggccacg tcccggaaat atgaagacct gttatgggca 11641 tgggagggct ggcgagacaa ggcggggaga gccatcctcc agttttaccc gaaatacgtg 11701 gaactcatca accaggctgc ccggctcaat ggtgagtcce tgctgccaac atcactggca 11761 cttgggtccc ttcattttcc tcaaagaggt getgtgaaac cccaagccta ggaaaggta ...

\begin{tabular}{|l|l|}
\hline \multicolumn{2}{|l|}{ Legenda } \\
\hline gt & começo de Intron \\
\hline ag & final de Intron \\
\hline & $\begin{array}{l}\text { região onde ocorre a deleção ou } \\
\text { inserção do fragmento Alu (287 pb })\end{array}$ \\
\hline Sequência ancorada nas plataformas & gagagcc actcccatcc tttctc \\
\hline Sequência conjugada com a nanopartícula & acagtcact tttatgtggt ttcgcc \\
\hline
\end{tabular}

... 11881 gctatgtaga tgcaggggac tcgtggaggt ctatgtacga gacaccatcc ctggagcaag 11941 acctggagcg gctcttccag gagctgcagc cactctacct caacctgcat gcctacgtgc 12001 gccgggccet gcaccgtcac tacggggccc agcacatcaa cctggagggg cccattcctg 12061 ctcacctgct gggtaagggc acatgtcggg ccttgaggag ggtaaagacg gaccacagtg 12121 tgagtgaggg ttgggacagg gctgactaga gggtagggag caggctgggg actgagagac 12181 tccagccctg tgggggatgg ttgcccaggc tggagggggg tgggcgctgg gagtggggag 
12241 ccccccactt gcatctggtg ccacattcac tgcagatcta tgtcgggcaa gtcaccatgg 12301 atgggggaag aagttaataa tcttgtccag gagaccacgg cacccatcac aacattgtgt 12361 gatcttagag ggcgaggaag aggctgtgag tgggagctgg ggaggctttg ccaagaggtg 12421 gcctgtgagc agggcctcgg aagatgacag ggtttgacag atgggaagtg ggggatgaga 12481 ggacagacgc agtgttcagg ccaagggaac tggaacaaag aagaacctga gaatgtaaat 12541 ctacttcaac cctggaccct cctttgccaa gggctgcaat ctcagatgcc ctgaatgtgt 12601 gaagtaggcg gtgaggacag taagggatgg tagggagtaa ggcaaagcag aggctactgg 12661 ttctctgtcc ctgatgggct gttaggaaca ctttcctgga gcagagagac cagacaggcc 12721 ctcagaccat ttagaaacta taagggaggc cccagaggac ggcetggctg tgggtctagc 12781 tcccacacag getgggagtc cagccetctt cagcccetct ctggtgagac caaagaacat 12841 ctggtgatgt cacagtggac gtcagttcac caactgggag acacaggccc cgggaagaaa 12901 agcaacatgc ccagcgtggc ctgggagctg gggcagagct ggccttagaa ctcagcccct 12961 gacaattggt aaaaggggaa aggggagcaa cctaacactg atgcgctctc tgtctctctc 13021 tctggctctc tccctggctc tctccctctt ctctctcatg ttctctccat cactcatcgc 13081 tctaaccctc tctcactggt ttgcactta gacttcatct gatgtcagcc gaagcttcac 13141 ctcacttggc taggaaagag ccttgagtcc aaatctgttt ctgagccttc cattcatcct 13201 gagtttcttc cttttcctct gtcgtggaga actaggctct tttcttacac taaactcaga 13261 ggcatcagcc tctcctgaag gagacggctg gttcctgtca gagttgctga gctgcagaca 13321 ccgacctcag gtggtgcgga ggggacatgg cagagtggct ggtgaagaga gcagcctgcc 13381 agcctttcaa tcccagccct gccacttagg agccgtgggc ccccggcgag gggggcggtc 13441 acttaactct ccagcctgtt tccttacta gccaatggga atcgtgacag tacctgggtg 13501 cagacaggat tgaaagtgaa ttcacacaat gttcttggtg cagagccaat aagaggtggc 13561 caccggggtg taggtgttct ggggacctgt aatgtcctca catgtcagca gttgctagtc 13621 acattggtct ccactgctca cggacagtga agaccacctg gattccctga taaccagcaa 13681 ggcccccacc tagagccagg cagtaatgac ctactgggct ggatatgcac accaaagatg 13741 atgtgtgcct caaagcttgc aaacagtagg tgctcaagaa atgccactat gattagcagg 13801 actgggatct ggagcgctct tcctgcagga gggcattgag cctaagtaac atttgtcttt 13861 cctctctctg ccgtccccca cactcgcctc cagggaacat gtgggcgcag acctggtcca 13921 acatctatga cttggtggtg cccttccctt cagccccctc gatggacacc acagaggcta 13981 tgctaaagca ggtccgcacc agcccagggg cagggaggce ccgccgggat gggagggacc 14041 ctctgattca ggagttccet ccagtttagc cctcccccgg gatccccacg gcagcacgca 14101 gtctgtcccc ggaaccccca gtttgggcag aactccctct gcttgcaggg ctggacgccc 14161 aggaggatgt ttaaggaggc tgatgatttc ttcacctccc tggggctgct gcccgtgcct 14221 cctgagttct ggaacaagtc gatgctggag aagccaaccg acgggcggga ggtggtctgc 14281 cacgcctcgg cctgggactt ctacaacggc aaggacttcc ggtacatcca gctagggctc 14341 aggtctcgtt cctgagcccc acgggcaagg gaaatgaacc aagcaaaggg tccactactg 14401 tcccccagct ggagccagca gggcaggatg gggacagggc cagagtttgg gactgagtgt 14461 ctagagaggt gttggcttct ggcaggaaaa ccccatccgc ctgatgggga cttctgaagc 14521 acgcaacagc tctgtcagcc tggccgctgg gaagtgctca aggtcccagt cctgggtttg 14581 agcatggtag gctgceccgc gtccetcctt gggagcagcc cctgcatgga gctggcctct 14641 ccctgggggc acatgctgtg acacagggag gcacacgagg atgttgggtg ctctgtacag 14701 atccactctc acccctgaca ggctcagaag ctgccttcct tggaggatgg cgttttagtt 14761 acctattgct gtgcaaccaa gcaccccaga gcttagcctt acgaaacaac cagttgattt 14821 tgcttatgat tttatgtgcc aggaattcag gcagtacaca gtggaatgg cctttctcta 
14881 cagggccccc tctgttgggg gcagctctca cagccgggat ggctcaatgg gggccatacg 14941 tccagagccc cagttctggc tgtcggttga ggtcctcggt ttttcccatg tggcagatgc 15001 tggggcacat gttcccagtg gcctcttggc tcacatgttg ggtgcttggg gtgagatggc 15061 tggaacggct ggaggtgggt caggcatctc tccaggctag ctcgggcgcc ctcccagcgt 15121 ggaatctgag gtgggcagat ttacctggca gccagcatcc cccacagcaa ctactgacgc 15181 agccagttct caaggctagg tccaaaactg gcccagagtc acttctgcca tgttttattg 15241 gctagaacaa gtcacaagtt cacccagatt caagagaaga gaaaaaagtc cctcccactt 15301 gggagaagtg gcaaagacca tctgtcacag ctgaagaagt gtctcttaca aggagaacag 15361 acacggggag cctgaaacaa aacccgatgg gattccctgg gctgtgcagg cccttccagg 15421 catgaggact cagccacagg getgagagga gacaggatct gggggatgag agccettgtg 15481 gggtcttccc ttttatgggg agtcagagga gaagctggat agatccccag ccttgtggcc 15541 aggatgctgg gcagctcttc cttccccetc cccgatgaga atgacagaaa aacaggattc 15601 acctgagcca aaggettcc agttagatcc aagagagaat ttcccgcagt ttgaattggt 15661 ttgctaaaca acaaggaagg gctgggtgcg gtggctcaca cctgtaatct cagcactttg 15721 ggaagccgag gcaggaggtc tgcttgagct caggggttcg agaccatcct gggcaacata 15781 gcgagacccc atttcataaa aataataa gtaaatgaga acaaggaagg actgacgaga 15841 gacggtagaa ccttctggtt tgggcagctc tgcagctgcc attcatcctg gccataagaa 15901 ttcttggggt gaataagttt gtcgctgttg ggccgcatga gatgcagaat cgcccactct 15961 cacccctgac agaaacagtt gtttccttca gggagcctcc atcttgggag ataaagcatg 16021 tgtacatggg aacccactgg ccacacattc tctagaaagt acacaatgtc ccagtgcctc 16081 tagagcaagc actttgtaca gtcagaaagc aacaggtggt gggggctgga gtcattcagg 16141 aaatgggag gcagaggaat ggcctgaacg gcccgatgct aggggcttct gcccccagat 16201 tccetcttac gcacactcag tggttgccet tcccetccet ccccacagtg ctgtgtcccc 16261 tgcatgctgc agtgctgggg tctgccctgg gtatagcaag gcccactgtt cccttatgcc 16321 cagggettct cactgtcctc tcccaacacc ctctccccca ctccactatt cctaggatca 16381 agcagtgcac caccgtgaac ttggaggacc tggtggtggc ccaccacgaa atgggccaca 16441 tccagtattt catgcagtac aagacttac ctgtggcctt gagggagggt gccaaccccg 16501 gcttccatga ggccattggg gacgtgctag ccctctcagt gtctacgccc aagcacctgc 16561 acagtctcaa cctgctgagc agtgagggtg gcagcgacgg tgagagagaa gcgggaggcc 16621 ctggtgggct gaggaccaag aaagggtggt gagcttggga ggtgggaaag gggcacttag 16681 tggcccatgg gcagaggtgt ggggcagagc aatcggaagg aagggagcca cccagaccat 16741 cccaggaggc aggtcacagg gcccaaagg tacagcaccc ccacccctcc accatcacag 16801 gcacaccagg gccaagccgc taggaccetg ggtctgacag ctgggctccc ttcccttgca 16861 gagcatgaca tcaactttct gatgaagatg gccettgaca agatcgcctt tatccccttc 16921 agctacctcg tcgatcagtg gcgctggagg gtatttgatg gaagcatcac caaggagaac 16981 tataaccagg agtggtggag cctcaggttc tggaacactc ccacgggatg cgggctgggg 17041 gatctctgcg agtgtctgca tgtgcctggg tgtctggatg ggccagggta ggggagtgtg 17101 tgtgtgtgtg tacactattg tgtctgtgca tatgatgtgt gtggtgtaag tgatggggaa 17161 aacggggtga ttgtgcacag aggcccagca cgcaggagaa tggggtgccc agtatagccc 17221 caagtgcagg gaccctccct caagtcaaaa atgccacccc cagcctggtt ctccccaaac 17281 tcatcttcca acatatattc ccactcgaca ggctgaagta ccagggcctc tgccccccag 17341 tgcccaggac tcaaggtgac tttgacccag gggccaagtt ccacattcct tctagcgtgc 17401 cttacatcag gtaacgggaa aggcaggagg gcacattgtg aggggcagta cccacagctt 17461 tgtgtttcaa ctgcggccac tgcccggtcc acaagctctg tcagtcaggg cagacccggg 
17521 ggagccggcc gcacggtgca ggtgcctggg cccactcaca ctgccaaggc tgatgggttt

17581 tttcttgaac attcttttga tgagagtctg taccatccaa acagttgaac acagaaactc

17641 aacctaataa ttggctaatg gttaccagac cttggttaag tagttaacat taaccacgac

17701 tcatggctgg atcatgagct ctgcactgtt ttgttttgct tttaaacaa gactgtgatt

17761 ctttactat tattgaacat tgtctgcgat acaattgaa ttgtacctgg aagcccttct

17821 agacactaaa atgtaggatt ggagatcggt taaggtggga ggcagggttg ctggggcaag

17881 ttacagtcac aggctggggt cagacagaac tgggttcaaa ctccgtctcc attactttgt

17941 ttccttgaga aaattcctca atttctgtga gcttccattt cctgacctgt gaaccccatt

18001 tcacaggatg cacgatggct aacttcttag cattctgtct catacacagc ctcctcaggg

18061 aggggtggcc aggaccccac tattcatcac tctctagtgg aatgtagctg cacactaggt

18121 ctgcaggtca catggccaca gatgagtgtg cccaatgcag cccctctcct tctgtgtgcc

18181 ccgggagagc acttgctgag ggctagcaag gctgtttgtg atccgggagg ctccctggga

18241 ggctgggggc tagagagacc tcaggctgga gttccaggtg cccccgggct acaggtagcc

18301 caggccaccc ccagagggct gtggctgcct ctggcectgg cctcccgtgg ttcctggaag

18361 cccagcaagg gcagggccca tgcccacctt gcctcctggc acctgggatg atgccagcac

18421 atcatcaagt gctaataact gattgtggga tggatgaagt ctgtccccag agtccaggaa

18481 gagggcatcc ctggagcacc tcagataggc ctgacctaga cggtgctcca gagatgacac

18541 ttaggacagg gctcccgcct gcctgctgga gtggtccctg gggttcccag ccggcgctgg

18601 ctctcacccg ggagccagct ggtgtgatgg ctagcttccc agcttaatgc agacaattct

18661 ccaaacaggg gtgggcaaag gagacttggc tgctctagaa aaacattccg gattctggcc

18721 agcagccttc acaaagcact tttaggaaag accagggaac taggtggtac atgcttgcac

18781 ccagcattca aagtgagagg cctgtgccac tggctcagga catttaaac ctcttcagac

18841 tttaagctgg ggagaatcct ccagccttga ctggcagatt tctaccaggg aattcgtgat

18901 gctttggata agatcatgta ggactggctt ccctgcccag accaccctag tagatccaca

18961 cggcccattt ggccacacct tgcctctact tgcatatacc ccagggatgg agacctcact

19021 gcctccaaag ccacctgcca gatctctgaa ggctctgccc tgaccccatg gagcaggccc

19081 tcctgagttg tggaggcagc tctgtgggtg ggaggcatct acacaggcac ggctaggaag

19141 aggctcagac aatgctaaga gctggggtgg gggagctcac cctgatagct gtgggcagag

19201 ttggggggcc ttggctctgc tgtgcgcatg tgacttagca cacatcacat gtgatgtgca

19261 gaagggcctg gggcccagtg gcacaaggcc ctcaaccaac tccgccccgg gccacggcct

19321 cgctctgctc caggtacttt gtcagcttca tcatccagtt ccagttccac gaggcactgt

19381 gccaggcagc tggccacacg ggccccctgc acaagtgtga catctaccag tccaaggagg

19441 ccgggcagcg cctggcgtga gtgtcctcca gccetccttt gtttccatgc tctggcctgc

19501 gcccctgggc cttgaggggt ctgtccactg gagcttttgt gggaacactt gccattttga

19561 gccgggaact cccacctgca gcgtgggcca ggcctgattg ccatctcctt aggcacctgg

19621 agccctgggg ccctgggaca agtttcagct gggagtgggt atggagagtg gatgtcaggt

19681 gggggcaaga ggggccatgt ccttctgact ctgcctccct gtctcatgcc tccccaggac

19741 cgccatgaag ctgggcttca gtaggccgtg gccggaagcc atgcagctga tcacgggcca

19801 gcccaacatg agcgcctcgg ccatgttgag ctacttcaag ccgctgctgg actggctccg

19861 cacggagaac gagctgcatg gggagaagct gggctggccg cagtacaact ggacgccgaa

19921 ctccggtacc gccacccacc ccacctccag ccttgggtct taaccccctc cccaggctgg

19981 gcagccatgc ggctgacctc ggagcetgge cetgceccgc accettgcec tgccetgccc

20041 tgcectgccc atgctgtctc cttgcttccc gctcagctcg ctcagaaggg cccctcccag

20101 acagcggceg cgtcagcttc ctgggcetgg acctggatgc gcagcaggcc cgcgtgggcc 
20161 agtggctgct gctcttcctg ggcatcgecc tgctggtagc caccetgggc ctcagccagc

20221 ggctcttcag catccgccac cgcagcctcc accggcactc ccacgggccc cagttcggct

20281 ccgaggtgga gctgagacac tcctgaggtg acccggetgg gtcggccctg cccaagggcc

20341 tcccaccaga gactgggatg ggaacactgg tgggcagctg aggacacacc ccacacccca

20401 gcceaccetg ctcctcctgc cetgtccetg tccccetcce ctcccagtcc tccagaccac

20461 cagccgcccc agcccettct cccagcacac ggctgcctga cactgagcce cacctctcca

20521 agtctctctg tgaatacaat taaaggtcct gccctcccca tctgagtctg tgtccctcac

20581 agggaagcca gggacaggga caggctgctt tcctgcctcc tggcagtcaa gtgggtcccg

20641 ttactaggtt tgttcctcca tcctccttca ggagccgggg aggatcccca gagctctgcc

20701 ccagcacctc ctggcgctgg cgcctgtctt ccctccagcc caggcagccc gecactgtcc

20761 tgccaccgca ggcagcccet gtctggccca agcactgacc cacgcggact ctgggaagca

20821 gacatcctgg gctgctggcc tcacatttcc actggcagtg gagcctttcc ctgctccaca

20881 aatggccagg tccccccagg ggaaggcttc cggctgttat cggctgcctc agggggcgag

20941 taccttggag ggcctgcttc aaggagggtg ccccctggag ggcacacacc agcctagtgc

21001 ttaccttggc tcctgcetgt accagctcca tgactctgct cgggtgaaca gccttggctc

21061 tcagacagcc attctaacac tgccagtgca gaggggcctc agacgctgga gtgtagcagt

21121 ggctgcacct gcacagggat tagctgccag cagccaccet gctggcgtcc cagcacacac

21181 ctcctcactc cctgcattgg agggagtgtc attttaaggg acatttttat gacttttatg

21241 tgtatgttta tgtagaaatt tggaaatac agaaaactgt aagaaaata aaagccctt

21301 atatcaacgt caagagataa 